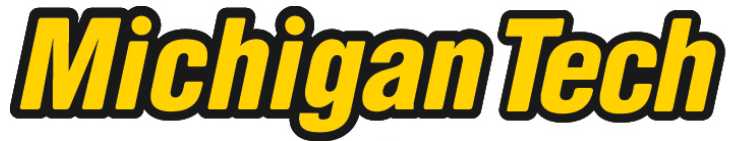 \\ Michigan Technological University Create the Future Digital Commons @ Michigan Tech
}

Dissertations, Master's Theses and Master's Reports - Open

Dissertations, Master's Theses and Master's

Reports

2009

\section{Quantifying the ecological benefits of lakeshore restoration in northern Wisconsin}

Daniel E. Haskell

Michigan Technological University

Follow this and additional works at: https://digitalcommons.mtu.edu/etds

Part of the Forest Sciences Commons

Copyright 2009 Daniel E. Haskell

\section{Recommended Citation}

Haskell, Daniel E., "Quantifying the ecological benefits of lakeshore restoration in northern Wisconsin", Master's Thesis, Michigan Technological University, 2009.

https://doi.org/10.37099/mtu.dc.etds/139

Follow this and additional works at: https://digitalcommons.mtu.edu/etds

8 Part of the Forest Sciences Commons 


\title{
QUANTIFYING THE ECOLOGICAL BENEFITS OF LAKESHORE RESTORATION IN NORTHERN WISCONSIN
}

\author{
By \\ Daniel E. Haskell \\ A Thesis \\ Submitted in partial fulfillment of the requirements \\ For the degree of \\ MASTER OF SCIENCE IN APPLIED ECOLOGY
}

MICHIGAN TECHNOLOGICAL UNIVERSITY

2009

Copyright (C) Daniel E. Haskell 2009 
This thesis, "Quantifying the ecological benefits of lakeshore restoration in northern Wisconsin," is hereby approved in partial fulfillment of the requirements for the Degree of MASTER OF SCIENCE IN APPLIED ECOLOGY.

DEPARTMENT School of Forest Resources and Environmental Science

Signatures:

Thesis Advisor

David J. Flaspohler

Department Chair

Margaret R. Gale

Date 


\section{ACKNOWLEDGEMENTS}

I thank my committee members, David Flaspohler, Chris Webster, John Vucetich, Casey Huckins, and Mike Meyer for their valuable comments and support at various stages of my thesis work. I thank my advisor, David Flaspohler, for his continued support, patience, and guidance throughout my tenure at MTU. I would also like to acknowledge Chris Webster, who served as my co-advisor and was instrumental in designing the down woody material experiment. He was always willing to take the time to discuss my research and provided me the advice that was above and beyond what was expected. I thank John Vucetich and Casey Huckins not only for their advice but for their perspective on scientific research as a whole. I especial thank Mike Meyer for trusting me with this project, his patience, endless support, and guiding this project from conception to conclusion.

Funding was provided by Wisconsin Department of Natural Resources, Wisconsin Department of Agriculture, Trade, and Consumer Protection, Vilas County Land and Water Conservation Department, Ecosystem Science Center, Wisconsin Society for Ornithology, and MTU Graduate Student Council. The dedication of the following field technicians and undergraduates smade a project of this magnitude possible: Danielle Drekich, Dan McGary, Casey Mehls, Tim Armstrong, Michele Pytleski, Mickey Jarvi, Adam Komar, Aaron Wuori, and Michael Bell. I thank Michele Woodford for her GIS wizardry and support in the field. I would also like to thank Quita Sheehan for her exceptional experience in collecting the botany data. Additional acknowledgement is paid to the graduate students at MTU for their guidance, advice and for putting up with my venting when things were not going quite as planned, to faculty for their support and 
willingness to listen, and especially to the front office staff for their assistance, support, and thoughtful encouragement and advice.

I thank Pat Goggin, Carolyn Scholl, Matt Wagner, and Stacey Denhe for designing and implementing the restoration plans and their assistance in the field. A special thanks goes to Brent Hanson for sharing his wealth of knowledge of native plant species with me, cooperating with landowners during a critical funding period, and for a positive attitude. Brent's support and willingness to work with me was instrumental in a successful outcome. I thank North Lakeland Discovery Center Bird Club volunteers for getting up in the early morning to collect bird data, Loren Ayers for providing Sherman traps and supplies for the small mammal component, and Gary Milanoski for working during the night to collect amphibian data. I am very grateful to the staff at Kemp Natural Resources Station for providing housing, office and storage space, technical support, field equipment and kindness. Additional thanks goes to Glen Svetnicka and the Moon Beach Camp staff for their support and the occasional lunch they provided for me and my crew.

A very special thanks goes to the residents on Found, Moon, and Lost Lakes for their trust in me and allowing me access to their properties; without their cooperation this project would have never occurred. In addition, I thank Chuck Thier for inviting me to work at Found Lake, building project support among lake residents, and assistance throughout my project. I am indebted to Jeff Wilson and Terry Dalton for assistance in landowner contacts and for their friendship and guidance. Their friendship over the years has made the Northwoods a very special place for me. 
I am deeply appreciative of my family and friends in Iowa. They probably thought I was crazy for changing careers and going back to school, but they were always supportive of my decisions and were always available when I needed someone to talk to. Words cannot describe how much I appreciate my two best friends, Amber Roth and Sava, without them in my life I could not have made it to the end of this project. Amber was always there for me when things were difficult, offering advice on everything from conducting surveys to data analysis to offering a supportive hug. Sava helped me keep things in perspective by always greeting me at the door with a smile, a wagging tail and a walk in the woods. 


\section{TABLE OF CONTENTS}

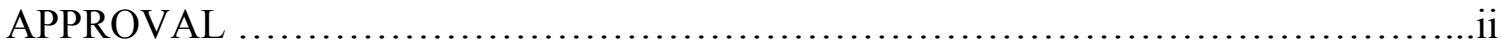

ACKNOWLEDGEMENTS........................................................

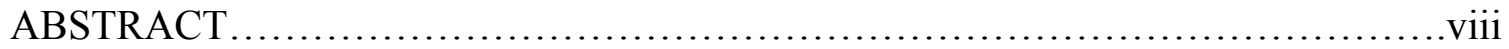

CHAPTER 1: VARIATION IN SOIL TEMPERATURE, MOISTURE AND PLANT GROWTH WITH THE ADDITION OF DOWN WOODY MATERIAL ON

LAKESHORE RESTORATION SITES.

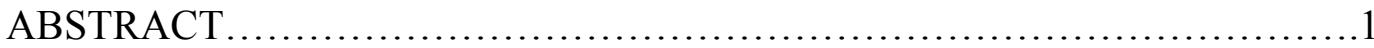

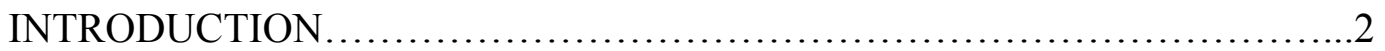

METHODS..........................................................

RESULTS........................................................... 12

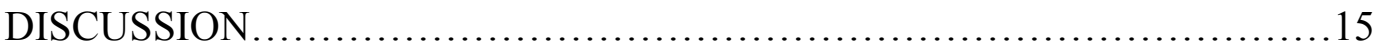

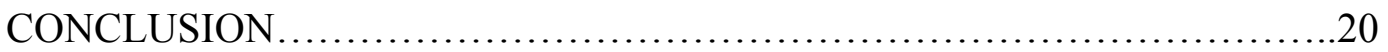

LITERATURE CITED ..................................................21

TABLES........................................................ 25

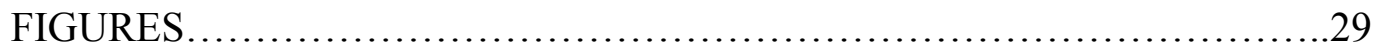

CHAPTER 2: RESIDENTIAL DEVELOPMENT IMPACT ON MAMMALIAN DIVERSITY ALONG LAKESHORES IN NORTHERN WISCONSIN................35

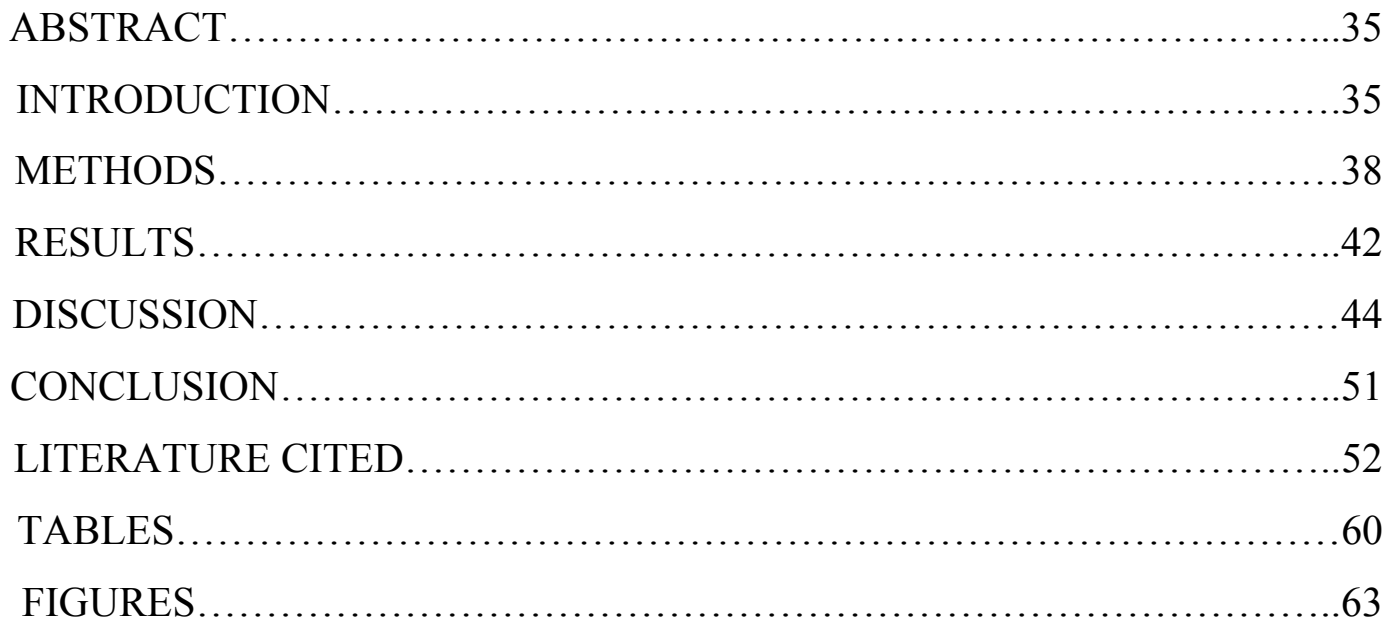


CHAPTER 3: BASELINE ASSESSMENT OF WILDLIFE HABITAT RESTORATION IN NORTHERN WISCONSIN: THE WISCONSIN LAKESHORE RESTORATION PROJECT .....................................................66

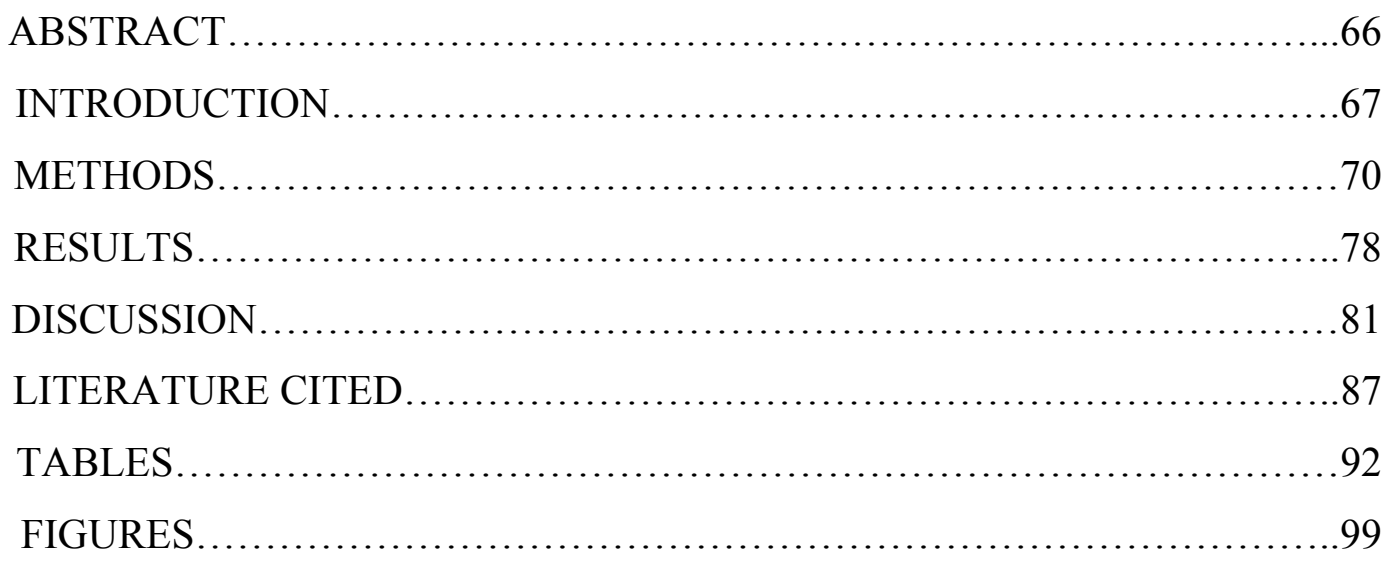




\begin{abstract}
Housing development has increased dramatically in the Midwest with a high concentration around lakes. This development plays an important role in the economy of Northwoods communities. However, poorly planned development has the potential to alter a lake's ecological processes and integrity. Studies have documented the impacts of housing developments and reported dramatic, negative changes to the flora and fauna in Vilas County, Wisconsin. One component of my research included examining the previously unstudied effects of residential development on the abundance and diversity of medium to large-bodied mammals using lakeshore ecosystems. The results suggest that a higher diversity of mammals were detected on low-development lakes. Coyotes were the most numerous species detected with the majority encountered on low-development lakes. White-tailed deer and red fox were more abundant on high-development lakes as compared to low-development lakes. I concluded that high-development lakes are having a negative affect on the mammal community in this area.

Recently, lakeshore restoration has occurred on privately owned property in Vilas County and elsewhere in the Northwoods, but little is known about the benefit, if any, from these restoration efforts. A partnership between government agencies and academia has launched a long-term research project investigating the ecological benefits of lakeshore restoration. I investigated the impacts of using down woody material (DWM) to increase the success of restoration projects. Specifically, I tested the hypothesis that down woody material would reduce the variation in soil temperature, retain soil moisture, and improve plant survival and growth rates. I randomly assigned three DWM coverage treatments $(0 \%, 25 \%$, and $50 \%)$ on $3 \mathrm{~m} \times 3 \mathrm{~m}$ experimental plots $(n=10$ per treatment $)$.
\end{abstract}


The mean maximum soil temperature, temperature variation, and change in soil moisture content were significantly lower in the $25 \%$ and $50 \%$ DWM plots. I found no difference in survival, but snowberry (Symphoricarpos albus) and Barren strawberry (Waldstenia fragaroides) growth was significant greater in the $25 \%$ and $50 \%$ DWM plots. DWM addition can be considered a useful technique to physically manipulate soil properties and improve plant growth.

Finally, I provided baseline data on vegetation structure, bird and small mammal community diversity and abundance for three lakes targeted for restoration efforts and their paired reference lakes. This study is one of the first of it kind in the area and continuing to document the degree of change in subsequent years will provide insight into the way the local ecosystem functions and how ecological communities are structured. 


\title{
CHAPTER 1
}

\section{VARIATION IN SOIL TEMPERATURE, MOISTURE AND PLANT GROWTH WITH THE ADDITION OF DOWN WOODY MATERIAL ON LAKESHORE RESTORATION SITES}

\begin{abstract}
Down woody material (DWM) is an important ecosystem component that performs many critical functions. Soil temperature and moisture can affect plant growth and survival. Residential development along lakeshores has increased dramatically in the past few decades in northern Wisconsin. Human development can have a dramatic effect on the presence of woody material in terrestrial and aquatic ecosystems. Shoreline restoration projects have occurred in the past few years in the region, but with little or no evaluation of success. In 2007 a collaborative lakeshore restoration research project was initiated on two lakes in Vilas County, Wisconsin. I investigated the benefits of the addition of DWM as part of these restoration projects. I randomly assigned three coverage treatments $(0 \%, 25 \%$, and $50 \%)$ of DWM on $3 \mathrm{~m} \times 3 \mathrm{~m}$ experimental plots $(n=10$ per treatment). I monitored soil temperature and volumetric soil water content at a depth of $10 \mathrm{~cm}$. Three soil temperature variables daily mean, daily maximum, difference in daily high and low, and percent change in moisture content following a watering event were compared among treatments. All plots were planted with two native shrub species and five native understory herbaceous species; change in plant canopy volume was compared among treatments. The mean maximum soil temperature, mean difference in daily high and low soil temperature, and percent change in soil moisture content were significantly lower in the $25 \%$ and $50 \%$ DWM plots. Plant canopy volume growth for snowberry (Symphoricarpos albus) and Barren strawberry (Waldstenia fragaroides) was significant
\end{abstract}


greater in the $25 \%$ and $50 \%$ DWM plots. I conclude the addition of DWM had a significant positive effect on soil temperatures, soil moisture, and plant volume growth for two species of native plants used for restoration projects.

\section{Introduction}

Down woody material (DWM) is vital to the function and structure of healthy terrestrial and aquatic ecosystems. DWM can come in many forms including standing and fallen dead trees, large branches, and is often abundant in natural forests, streams (Harmon et al. 1986), and lake ecosystems (Christensen et al. 1996, Marburg et al. 2006). Input mechanisms of DWM into a system include wind throw, insects, diseases, and beaver (Castor canadensis) activity which can display an aggregated spatial pattern (Harmon et al. 1986) adding complexity to the forest floor and below ground heterogeneity (McComb 2008). Many people consider DWM to be a waste of wood fiber and a fire hazard which can lead to multiple and sometimes conflicting values. However, DWM performs many crucial ecological functions such as habitat, energy flow and nutrient cycling, influencing soil and sediment transport and storage (Harmon et al. 1986), and providing nursery sites for germination of plants (Gray and Spies 1997, Rasmussen and Whigham 1998). In addition, DWM provides organic matter to the soil, enhances infiltration capacity of water runoff, creates microclimates (Harmon et al. 1986, Reid et al. 1999), moderates flow of organic matter from terrestrial ecosystems into aquatic systems (Bormann and Likens 1979, France et al 1998, Hagan and Grove 1999), and is a

critical factor influencing interactions between terrestrial and aquatic ecosystems (Harmon et al. 1986). 
DWM provides critical habitat for a variety of wildlife species. Small mammals and amphibians use DWM for cover, nesting, foraging, and connectivity across the forest floor (Jaeger 1990, Tallmon and Mills 1994, Stevens 1997, Ucitel et al. 2003, McComb 2008). Depending on the size and volume of DWM, it provides crucial habitat for small too mid-size carnivores (Gilbert et al. 1997), courtship sites for ruffed grouse (Bonasa umbellus), and perching, feeding, mating and nesting sites for a variety of bird species (Maser et al. 1979). Many invertebrates use and are dependent on DWM in one form another as food, shelter, and as a site for breeding (Harmon et al. 1986). Furthermore, many decomposer bacteria and fungi utilize DWM as an energy and nutrient source as well as habitat (Harmon et al. 1986).

DWM also influences the abiotic environment such as acting as moisture reservoir and ground surface temperatures (Harmon et al. 1986, Gray and Spies 1997). Soil temperature and moisture can affect plant and root growth (Russell 1973), nutrient uptake (Dong et al. 2001), and plant survival and productivity which may contribute the success or failure of flora restoration projects (Castro et al. 2002). The effect of soil moisture content on soil temperature is complex. Moist soils conduct heat vertically more efficiently than dry soils. During a sunny day the surface of dry soils warm quicker and at night cool quicker (Russell 1973). Therefore, dryer soils should have greater daily differences in temperature. The amount of radiation received affects soil temperature (Russell 1973) and varies depending on the aspect, slope and percent canopy cover. Thus, a south facing slope would potentially have greater differences in daily soil temperatures than a north facing slope due to greater sun exposure. Dry sandy soils will 
commonly heat up quicker in the spring and throughout the growing season than sandy loam or clay soils (Russell 1973).

In the last few decades humans have had a propensity for development in and around natural areas. Lakes, streams, and forested areas attract residential development because they provide a clean environment, opportunities for recreation, and scenery (Schnaiberg et al 2002). Northern Wisconsin contains the third largest density of freshwater glacial lakes in the world, with more than 12,400 lakes scattered across the northern third of the state (WDNR 1996). Vacationers have been attracted to this region for decades, and more recently, increasing numbers of people are replacing small seasonal cottages with large year-round houses along lakeshores in this region. In parts of the northern Great Lakes region, this growth has been concentrated around inland lakes (Radeloff et al. 2001, Gonzales-Abraham et al. 2007). Since 1965, two thirds of previously undeveloped inland lakes in northern Wisconsin (i.e. lakes with no residential housing) have since become developed with homes and cottages near the shoreline (WDNR 1996).

Many studies have reported a significant reduction of trees, shrub layer, and DWM on high-development compared to low-development lakes (Christensen et al. 1996, Elias and Meyer 2003, Marburg et al. 2006). Some residents equate lakeshore beauty with park like conditions of manicured lawns and scattered trees (Macbeth 1992). Human land-use practices have significantly altered DWM in ecosystems for decades which may alter productivity of several organisms, reduce biodiversity, and disrupt ecosystem function (Harmon et al. 1986). Removal of DWM and vegetation structure 
along shorelines on high-development lakes is a common practice especially following storm events.

The Great Lakes region is one of the most active weather zones in the northern hemisphere (Frelich 2002). In 1999, the residents of Found Lake, Vilas County, Wisconsin experienced a thunderstorm with high winds. The storm's path followed the north shoreline toppling hundreds of trees in its wake, including trees estimated at 100 years old, thus opening the overstory canopy along the shoreline. A similar wind storm occurred in 2005 on Statehouse Lake in Vilas County, home to the North Lakeland Discovery Center (NLDC). The DWM was removed by residents leaving the understory vegetation exposed to environmental elements (sun, extreme temperatures, wind, and precipitation) and human activity. In the following years, a die off of understory vegetation occurred with little regeneration and soil erosion increased at and near the shoreline. However, where DWM was retained, some regeneration of vegetation had occurred (personal obs.).

In the summer (July-August) of 2007, Wisconsin Department of Natural Resources (WDNR), Michigan Technological University, Vilas County Land and Water Conservation Department (VCLWD), and Wisconsin Department of Agriculture, Trade and Consumer Protection (WDATCP) launched a long-term ( $\geq 10$ years) research project investigating the potential positive impacts of shoreline restoration on riparian and littoral communities in Vilas County, Wisconsin. This restoration project requires property owners to plant native trees, shrubs and ground cover plants within a 35-foot buffer zone along the shoreline and to correct erosion problems. Several landowners on Found Lake and NLDC expressed interest in this project and enrolled in the VCLWD shoreline 
restoration cost share program. This program is funded annually by the WDATCP. Lakeshore restoration projects in Vilas County have been ongoing since 2000 costing $\$ 30,000$ to $\$ 60,000$ annually, depending on the budget cycle (C. Scholl VCLWD conservationist, personal comm.). However, little or no evaluation of these past projects has occurred to identify the factors that affect the success of restoration. Furthermore, soils in Vilas County range from loam to sandy soils (NRCS 1986) and in the past few years the region has been in a historical drought with record breaking ambient temperatures (http://mrcc.sws.uiuc.edu/climate_midwest). The soil types and current weather regime could profoundly affect the success of these restoration projects.

Shoreline restoration is a relatively new practice in northern Wisconsin. Prior evaluation of lakeshore restoration has focused on vegetation planting techniques (Weiher et al. 2003) but not on restoration of other attributes including ecological function and long-term plant survival and growth. In order to better understand the dynamics and benefits of lakeshore restoration, I added DWM to seven restoration projects with three coverage treatments of DWM and monitored the soil temperature and moisture content over the course of the growing season. I also recorded the first year survival and plant canopy volume growth of several native plant species within these treatments.

The objectives of my research were to (1) determine if DWM addition will reduce the difference between low and high daily soil temperature and moisture on restoration sites, (2) provide first year data on plant survival and growth rates, (3) and provide a better understanding of how the presence of DWM may affect the success of lakeshore restoration. I hypothesized that the addition of DWM to restoration sites, soil 
temperatures and moisture would vary less during the growing season. Furthermore, plant survival and growth will be greatest with the presence of DWM.

\section{Methods}

Study area and site selection. - This project was conducted on two lakes in a forested landscape on deep sands with pitted glacial outwash in Vilas County of northern Wisconsin (Stearns and Likens 2002). The first study site is located along $1500 \mathrm{~m}$ of the north-northeast shoreline of Found Lake (T40N, R8E, Section 14). Found Lake is a drainage lake with a surface area of $131 \mathrm{ha}$, a maximum depth of $7 \mathrm{~m}$, and is accessible to the public (WDNR 2005). Found Lake was home to several fishing resorts in the past, but in recent decades, these resorts have been sold to developers and parceled for resale to individuals for seasonal or permanent homes. In addition, recent construction of larger dwellings has occurred on Found Lake with little or no regard for a vegetated buffer zone near the shoreline, though mature trees were often maintained or preserved. The second study site is located along $40 \mathrm{~m}$ of the northeast shoreline of Statehouse Lake (T42N, R5E, Section 5). Statehouse Lake is a seepage lake with a surface area of 9.3 ha, maximum depth of $6 \mathrm{~m}$, and is surrounded by public lands (WDNR 2005). Statehouse Lake is home to NLDC, formerly a Youth Conservation Camp, which has a 26.7 ha campus community-based environmental learning center that promotes stewardship of the region's natural and cultural resources. The combination of human impact and the wind storms in the past have left these shorelines in a degraded state. Therefore, on both study sites regeneration of vegetation is low and soil erosion is occurring thus making both shorelines prime candidates for lakeshore restoration. Both lakes are within the Northern Highland Lake District. The mean daily ambient air temperature is $3.4^{\circ} \mathrm{C}$, 
ranging from $-2^{\circ} \mathrm{C}$ in January to $10^{\circ} \mathrm{C}$ in July and the mean precipitation is $80.25 \mathrm{~cm}$ (http://mrcc.sws.uiuc.edu/climate_midwest).

Experimental Design - Restoration activities occurred on six privately owned properties on the north-northeast shore of Found Lake and State House Lake during the summer of 2007 (July-August). Thirty $3 \mathrm{~m} \times 3 \mathrm{~m}$ experimental plots were placed within these restoration areas, 24 on Found Lake and six on the State House Lake site. Ten sets of three experimental plots $(0 \%, 25 \%$, and $50 \%)$ were established. Two properties on Found Lake and State House Lake site were large enough to place two sets of experimental plots. Each set of experimental plots were placed in line and parallel with the shoreline and $3 \mathrm{~m}$ inland from the original high water mark. This placed the experimental plots in the middle of the 35 -foot state mandated buffer zone (see Wisconsin's Shoreland Management Program, chapter NR 115), a consistent distance from the shoreline, and far enough from the lakeshore edge to minimized the risk of high wave action. The three plots were place 0.5 to $1.0 \mathrm{~m}$ apart. A random number table was used to assign three coverage densities of DWM to each experimental plot (Figure 1.1).

1) 50 percent of area covered by DWM $(n=10)$.

2) 25 percent of area covered by DWM $(n=10)$.

3) 0 percent of area covered by $\operatorname{DWM}(n=10)$, control treatment.

Woody material is defined as branches $\geq 2.5 \mathrm{~cm}$ and $\leq 15 \mathrm{~cm}$ in diameter and $\leq 3 \mathrm{~m}$ in length. All DWM was northern red oak (Quercus rubra) acquired from a recent (within one year) logging site nearby. All experimental plots were protected from herbivory with $2.4 \mathrm{~m}$ high nylon fences erected around the perimeter of each restoration area. 
In each experimental plot I planted three shrubs and 25 forbs and grasses. One snowberry (Symphoricarpos albus) $(n=30)$ and two sweet fern (Comptonia peregrine $)(n=60)$ comprised the shrubs species for each experimental plot. For each shrub one liter of organic compost was incorporated into the soil before shrubs were planted. I planted five of each of the following forbs and grasses, little-blue stem (Schizachyrium scoparium) $(n=150)$, Barren strawberry (Waldstenia fragaroides) $(n=$ 150), pearly everlasting (Anaphalis margaritacea) $(n=150)$, bergamot (Monarda fistulosa) $(n=150)$, and large-leaved aster (Aster marcophyllus) $(n=150)$. A total of 90 shrubs and 750 ground cover individuals were planted and uniquely identified with a numbered metal tag. The location of each individual plant within the plot was mapped for future relocation. Plant densities were based on recommendation from the Wisconsin Biology Technical Note 1: Shoreland Habitat (NRCS 2002). Snowberry shrubs were delivered in 3-gallon nursery containers, sweet fern in 1-gallon nursery containers, and all ground cover species were in 2 - inch nursery containers. A local nursery (Hanson's Garden Village, Rhinelander, Wisconsin) supplied all plant material.

Abiotic variables. - All abiotic data were collected prior to DWM installation. Soil samples were collected from each experimental plot $(n=30)$ and analyzed for organic matter and nutrients at the Soil \& Plant analysis Lab, UW-Madison. Slope, aspect, and canopy gap fraction ( $n=29 ; 1$ plot missing in 50\% DWM treatment) were measured on each plot. I determined the slope and aspect using a Silva Ranger compass with built-in clinometer. In order to quantify the gap fraction, I took a digital hemispherical photograph (Nikon Cool Pix 5000 and FC-E8 fisheye converter) at $50 \mathrm{~cm}$ above the ground and centered in each plot. Digital hemispherical photographs were analyzed with 
the software WinSCANOPY (WinScanopy 2005). Gap fraction is defined as a fraction of pixels classified as open sky in a region in the image [Gap fraction $=$ number of pixels classified as sky in a region/total number of pixels in a region (WinScanopy 2005)]. In each experimental plot two microenvironment characteristics (soil temperature and moisture) were measured.

Soil Temperature. - From each plot corner a temperature data logger (Standard Logger, KoolTrak, Inc) was placed systematically $1 \mathrm{~m}$ inward at a 45 degree angle and at a depth of 10 centimeters in each plot $(n=120)$. I deployed all loggers 4-6 weeks prior to restoration which provided data before the applied DWM. All loggers were programmed to record soil temperatures every hour during the growing season (May $6^{\text {th }}$ to September $26^{\text {th }}$ ). I computed the means and standard errors for three soil temperature variables (daily maximum, daily mean, and difference between low and high daily temperature).

Soil Moisture.-Four soil moisture readings (volumetric soil water content) were measured on each plot within $5-10 \mathrm{~cm}$ of temperature sensor locations. Data was recorded manually using a hand held soil moisture sensor (HydroSense CS620, CD620, $12 \mathrm{~cm}$ probes, Campbell Scientific, Inc., Logan, Utah). All data was recorded 12 hours after a weekly watering event (irrigation or precipitation) and then again 24 hours after the first reading. I collected soil moisture data for two months during the 2008 growing season (July $n=25 /$ treatment, August $n=34 /$ treatment). The monthly (July-August) means of percent change between moisture readings was calculated. Rainfall and irrigated water quantities were measured with plastic rain gauges. If precipitation was not adequate, 10-30 mm within a week, each plot was irrigated using a gas or electric water pump with oscillating sprinkler system. 
Plant survival and growth. -Plant measurements included height and canopy area. Height was measured from the soil surface to the highest point of the living tissue in its natural state. Plant canopy area was determined by measuring the width of the canopy at it widest point, then a second width perpendicular to the first. The mean of the two widths was used to calculate the canopy radius and circular canopy area. The height and canopy area were used to compute the cylindrical volume $\left(\mathrm{m}^{3}\right.$ ) for each plant (Bussler $e t$ al. 1995). The percent change in cylindrical volume $\left(\mathrm{m}^{3}\right)$ for each plant was calculated based on measurements at two time periods and indicates plant growth. Shrub species were measured at the time of planting in 2007 and again in mid-August 2008. Forbs and grass species were measured in late May and again in mid-August 2008. Forbs and grass species were propagated under artificial light at local nursery which affected their initial height at the time of planting.

Plant survival (alive or dead) was recorded one year after planting. All shrub and ground cover individuals were included in the survival comparisons. All individual shrubs were used for growth volume analyses. Some ground cover individuals were missed during the initial measurements in May 2008 but were located in August; I excluded the missing individuals in May and all summer mortalities from ground cover volume growth analyses.

Data Analyses. - The means for soil temperature variables were calculated with the software KoolTrak. Monthly soil temperature and moisture data were subjected to analysis of variance (ANOVA) using a one-way procedure within SigmaStat 3.5 software (Systat Software Inc. 2006) to test for differences in soil temperature and moisture across DWM treatments. I also used ANOVA to compare the slope, aspect, soil organic matter, 
and canopy gap fraction across treatments. The Holm-Sidak method was used for all pair-wise multiple comparison tests. For ANOVA tests, I determined if all test assumptions (normality and equal variance) were met. The Kolmogorov-Smirnov test was used to test for normally distributed samples. I used arcsine square roots and natural logarithms to transform independent variables to meet normality assumptions. When transformation of variables was unsuccessful in producing a normal distribution, I used the nonparametric Kruskall-Wallis test. The Tukey method was used for all pair-wise multiple comparison tests for nonparametric data. All statistical tests were set at $\alpha=$ 0.05 .

\section{Results}

Abiotic variables. - I found no significant differences in slope $(\mathrm{H}=0.0126, \mathrm{df}=2, P=$ $0.994)$, aspect $(\mathrm{H}=0.000, \mathrm{df}=2, P=1.000)$, soil organic matter $\left(\mathrm{F}_{2,27}=0.790, P=\right.$ $0.464)$, and gap fraction $(\mathrm{H}=1.252, \mathrm{df}=2, P=0.535$; Figure 1.2) between DWM coverage treatments (Table 1.1).

Soil Temperature. - The soil temperature data collected prior to DWM installation in 2007 revealed no significant differences between experimental plots for the three temperatures variables (Table 1.2). I collected daily soil temperature data during the 2008 growing season for144 days resulting in 13,824 temperature samples (Figure 1.3). I discovered no significant differences in the average daily temperatures (June: $F_{2,27}=$ $1.780, P=0.188$; July: $\mathrm{F}_{2,27}=2.285, P=0.121$; August $\mathrm{F}_{2,27}=3.141, P=0.059$ ) (Figure 1.4, Table 1.3). However, the average maximum daily temperature per month revealed a significant difference (June: $\mathrm{F}_{2,27}=3.700, P=0.038$; July: $\mathrm{F}_{2,27}=6.050, P=0.007$; August $\left.\mathrm{F}_{2,27}=9.042, P=<0.001\right)$. The $25 \%$ and $50 \%$ DWM coverage plots were $2-3^{\circ} \mathrm{C}$ 
cooler than the $0 \%$ coverage plots from June through August (Figure 1.4). Furthermore, I unearthed a significant difference between low and high daily soil temperature per month (June: $\mathrm{F}_{2,27}=6.506, P=0.005 ;$ July: $\mathrm{F}_{2,27}=11.894, P=<0.001$; August $\mathrm{F}_{2,27}=14.658$, $P=<0.001)$. The difference between low and high daily soil temperatures were reduced in the $25 \%$ and $50 \%$ DWM coverage plots by over $2^{\circ} \mathrm{C}$ in June and $3-4^{\circ} \mathrm{C}$ in July and August (Figure 1.4). Pair-wise multiple comparisons found no significant difference between $25 \%$ and $50 \%$ DWM coverage plots for both daily maximum and difference between low and high daily temperatures.

Soil Moisture. - In July, mean percent change in moisture content was $21.4 \%$ ( \pm $0.0156)$ for $0 \%$ DWM coverage, $7.3 \%( \pm 0.00985)$ for $25 \%$ DWM coverage, $4 \%( \pm$ 0.00979 ) for $50 \%$ DWM coverage and was significantly different across treatments (July: $\left.\mathrm{F}_{2,27}=58.964, P=<0.001\right)$. Pair-wise multiple comparisons found no difference between 25\% and 50\% DWM coverage in July. For August moisture data was similar to July for each plot, $19 \%( \pm 0.0156)$ for $0 \%$ DWM coverage, $8.6 \%( \pm 0.008)$ for $25 \%$ DWM coverage, $5.2 \%( \pm 0.007)$ for $50 \%$ DWM coverage (August $\mathrm{F}_{2,27}=66.511, P=$ $<0.001)$; however, pair-wise multiple comparisons showed significant differences between all three coverage treatments (Figure 1.5).

Plant survival and Growth. - All 30 S. albus shrubs survived the first year after planting and 59 out of 60 C. peregrine (99.98\%) survived the first year after planting. One $C$. peregrine died in a 50\% DWM cover plot. However, I did find a significant loss in $S$. albus canopy volume growth over one year $\left(S\right.$. albus: $\left.F_{2,27}=4.961, P=0.015\right)$. $S$. albus shrubs in 0\% DWM treatment plots experienced a $14.3 \%( \pm 0.0849)$ decline in mean canopy volume $\left(\mathrm{m}^{3}\right)$ (Figure 1.6). Pair-wise multiple comparisons found no 
significant difference between $25 \%$ and $50 \%$ DWM, and also between $0 \%$ and $25 \%$ DWM coverage for $S$. albus canopy volume data. There was no significant difference in C. peregrine canopy volume after one year $\left(F_{2,27}=1.398, P=0.264\right)$. C. peregrine canopy volume data required a natural logarithm transformation to produce a normality distributed sample.

All ground cover species combined exhibited a $92.8 \%$ survival rate. The data may suggest that there is no significant difference of ground cover survival between treatments of DWM. M. fistulosa had the lowest survivor (85.3\%) rate while $W$. fragaroides exhibited the highest survival rate (98\%) (Table 1.2). The ground cover canopy volume data revealed no significant difference for four out of the five species ( $A$. margaritacea: $\mathrm{H}=1.280, \mathrm{df}=2, P=0.527 ;$ Aster marcophyllus: $\mathrm{H}=2.191, \mathrm{df}=2, P=$ 0.334; M. fistulosa: $\mathrm{H}=0.281, \mathrm{df}=2, P=0.869 ;$ S. scoparium: $\mathrm{H}=2.255, \mathrm{df}=2, P=$ 0.324). The growth patterns for A. margaritacea and A. marcophyllus had a 2-4 times increase in mean volume in 50\% DWM plots compared to the $0 \%$ and $25 \%$ DWM plots, but variability was the highest in the $50 \%$ DWM plots. $W$. fragaroides canopy volume data revealed a significant difference $(\mathrm{H}=6.991, \mathrm{df}=2$ degrees, $P=0.030)$ with a mean of $-10 \%( \pm 0.225)$ in $0 \%$ DWM coverage plot. Pair-wise multiple comparisons found a significant difference between $0 \%$ and 25\% DWM plots but no significant difference between other pairs for $W$. fragaroides canopy volume data. The large standard errors for canopy volume for ground cover species suggest there is much variability (Table 1.4). Several individuals were overlooked in May for the initial measurements which may have an effect on the sample size and variability in the data. 


\section{Discussion}

Restoration efforts on disturbed sites with native vegetation are dependent on successful establishment and survival of plant species. The effects of soil temperature and evaporation rates are important for both herbaceous and woody plants. The loss of moisture by soil evaporation reduces the amount of water available to plants, which can have negative effects on plant growth and survival and thus on the success of the restoration projects. Bhattacharjee et al. (2008) reported the rate of soil moisture decline was the single most important variable influencing cottonwood (Populus deltoides) seedling survival in sandy soils.

Addition of DWM lowered the difference between low and high daily soil temperature, the maximum daily temperatures, and the percent change in soil moisture content relative to plots without DWM. The percent change in soil moisture content was less on the $25 \%$ and $50 \%$ DWM coverage compared to $0 \%$ DWM coverage in July and August. The mean percent change in moisture content for $0 \%$ DWM coverage plots increased 3-5 fold compared to the $25 \%$ and 50\% DWM coverage plots. There was a slight increase in moisture change for the 25\% and 50\% DWM coverage plots in August, which correlates with an increase of ambient temperatures and drought conditions during that time (http://mrcc.sws.uiuc.edu/climate midwest). However, 0\% DWM coverage experienced a slight decrease in percent change of moisture content between months.

Although DWM has been shown to play a number of important roles in terrestrial ecosystems, to my knowledge no studies have investigated soil temperature and moisture relative to DWM coverage and how these factors affect plant survival and growth. Gray and Spies (1997) compared surface temperatures and western hemlock (Tsuga 
heterophylla) seedling survival on north and south sides of large logs $(\sim 50 \mathrm{~cm}$ in diameter). They found that surface temperatures were lower on the north side of logs, and western hemlock seedling survival was higher within $15 \mathrm{~cm}$ of the north side of logs than on the south side. They suggest that shade from large logs facilitated establishment of western hemlock seedlings in large gaps exposed to direct solar radiation in a mature to old growth conifer forest. Breshears et al. (1998) looked at the influence of forest canopy density on soil characteristics and found that soil temperatures and soil evaporation rates were lower under woody plant coverage compared to soils with no canopy coverage. Additionally, Callaway (1992) found that certain species of oak (Quercus spp) seedlings had higher survival and root elongation rates in a shaded canopy of shrubs in southern California. A number of restoration projects have used shrubs and grasses as nurse plants to facilitate early establishment of seedlings in restoration projects in the Mediterranean region (Maestre et al. 2001, Castro et al. 2002 \& 2004), and in northern Africa (Aerts et al. 2007). These studies reported higher seedling survival under shrubs and grasses which reduced solar radiation and slow the soil-water evaporation and seedling transpiration. However, these studies were conducted in semiarid woodlands where ambient temperatures are twice as high and precipitation is half that in northern Wisconsin. It is well established that soil temperature and moisture influence plant survival.

My soil temperature and moisture data positively correlates with the increase in $S$. albus canopy volume data within the $25 \%$ and $50 \%$ DWM coverage plots. However, there was no significant difference for C. peregrine canopy volume among treatments. Because C. peregrine has adapted to open, sterile, sandy and gravelly soils with low to 
neutral pH (Hightshoe 1988, Soper and Heimburger 1994), it may be more tolerant of dry conditions than S. albus. Additionally, C. peregrine is a nitrogen-fixing plant which is used primarily for ground cover and erosion control on steep sandy soils (NRCS 2002). C. peregrine may tolerate transplant shock better than S. albus and may efficiently utilizes the compost that was added to each shrub. S. albus is also considered a plant that will tolerant well drained sandy soils (Hightshoe 1988, Soper and Heimburger 1994, and Smith 2008). However, the decrease in S. albus canopy volume in $0 \%$ DWM coverage plots may suggest that $S$. albus may have difficulty establishing in drier conditions without supplement of DWM or water. Yellowing of leaves of S. albus was prevalent among plants in all treatments which may suggest that it was lacking nutrients. There is some contradiction in the literature about the preferred soil and moisture regimes for $S$. albus. For example Henderson (1987) suggests that it grows best in moist and clay soils as compared to drier, sandier soils suggested by Hightshoe (1988), Soper and Heimburger (1994), and Smith (2008). Nevertheless, both species are native to the area and are highly recommended by county conservationists and local nursery personnel for lakeshore restoration projects.

The ground cover species used in this study are adapted to moderate to dry soil conditions and are also highly recommended for use in lakeshore restoration projects. $W$. fragaroides may have lost canopy volume in the $0 \%$ DWM coverage plots between treatments because it is a spring ephemeral and blooms early in the spring. Drier soil conditions later in the year may result in plant desiccation. The $25 \%$ and $50 \%$ DWM coverage plots may have retained enough soil moisture to slow plant desiccation of $W$. fragaroides. It is also a mat forming plant that spreads by runner-like rhizomes below the 
ground surface. These growing characteristics may be beneficial in dry, sandy soils conditions which allow the plant to take advantage of early spring soil moisture and use less energy to spread on top of or near to the soil surface. It also exhibited the highest survival rate among all ground cover species. M. fistulosa experienced the lowest survival rate, which may reflect its preference for more moderately moist and loamy soils. S. scoparium showed the largest increase in canopy volume across all treatments. This is perhaps because it is a warm season grass that grows slowly until mid-summer. $S$. scoparium is one of the most widely distributed native grasses in North America. It will grow on a wide variety of soils but is well adapted to well-drained, medium to dry, infertile soils. The plant has excellent drought and partial shade tolerance (NRCS 2002). Because of its growth habit and adaptability to a wide range of soil conditions, $S$. scoparium may be useful as a component of lakeshore restoration projects. Nevertheless, it suffered the second highest mortality rate. The huge increase in the mean canopy growth and variability for A. margaritacea and A. marcophyllus in the 50\% DWM plots may be do the fact that $A$. marcophyllus prefers partial shade; the opposite may be true for A. margaritacea which prefers more open sites. However, I found no significant difference in the gap fraction across treatments these species may be more sensitive to the amount of openness hence the large variability in the canopy volume standard errors. Additional evaluation and measurements of abiotic factors may be necessary to fully understand species-specific mechanisms governing growth.

The southern aspect may have a greater influence on growing rates along lake shores with sandy soils as compared to northern, eastern and perhaps western aspects. In the absence of irrigation plant mortality may have been higher and plant canopy volumes 
reduced especially, in drought conditions. DWM may also reduce the microclimate stress on plants during the night in early spring. Because nighttime temperatures are lowest at or near bare soil surfaces causing frost and adding stress to newly planted seedlings, DWM may reduce thermal imbalance at the soil surface by absorbing and storing infrared radiation during the day and protecting fragile plants at night (Ehleringer and Sandquist 2006). In this study, DWM did show that it can stabilize soil temperature and reduce soil moisture loss throughout the growing season which could have a positive effect on plant growth and survival in the following years.

Significantly degraded sites may require physical manipulation of soil properties (physical, chemical, or biological) to improve restoration success. Some restoration projects may be limited to focusing on one specific structure or process to improve plant success. Heneghan et al. (2008) reviewed many physical manipulations that have been successful in restoring soil characteristics with a positive effect on plant growth and community composition. Though these techniques are often effective, they can be time consuming and expensive, making them impractical for certain restoration projects. They argue that soil ecology should be considered in restoration projects.

DWM may also provide other positive functions in restoration projects such as reducing soil erosion on steep slopes (Hagan and Grove 1999). Sediment runoff from the lake shoreline can have negative effects on aquatic systems (Engel and Pederson 1998). I observed sediment accumulation on the upward side of DWM on steeper slopes indicating the DWM was reducing sediment runoff into the lake. 


\section{Conclusion}

The upper Midwest has experienced moderate to severe drought conditions with abnormally high temperatures over the past several years. In Vilas County during 2007, record low precipitation and high ambient temperatures resulted in record low lake water levels. In 2008, temperatures were relatively normal but drought conditions continued and reached severe levels in late summer months (http://mrcc.sws.uiuc.edu). The aspect, slopes, and sandy soils at these restoration sites coupled with the weather conditions can put extreme stress on recent plantings. Previous restoration projects in the area have used cedar mulch on woody plant species to minimize soil-water evaporation. However, cedar mulch has a tendency to require continuous maintenance over the summer months due to high winds or being washed away during rain or irrigation events. This was especially problematic on steeper slopes (personal obs.), and if mulch is applied too heavy it may hinder recruitment of plants in the area. The amount of DWM available for lake riparian is related to the vegetation structure in the area (Christensen et al. 1996). While planting trees and shrubs into restoration sites will provide DWM through natural succession, trees grow slowly and it may take decades to centuries for DWM to be replenished naturally along high-development lakes (Christensen et al. 1996). Elias and Meyer (2003) advocate the active input of DWM.

DWM addition reduced the difference between low and high daily soil temperatures and the change in soil moisture and thus can be considered a useful technique to physically manipulate soil properties. However, longer term monitoring of plant survival and growth may be required to fully understand the effects of DWM (see Castro et al. 2004). 


\section{LITERATURE CITED}

Aerts, R., A. Negussie, W. Maes, E. November, M. Hermy, and B. Muys. 2007. Restoraion of dry afromontane forest using pioneer shrubs as nurse-plants of Olea europaea spp. Cuspidate. Restoration Ecology 15:129-138.

Bhattacharjee, J., J.P. Taylor, JR., L.M. Smith, and L.E. Spence. 2008. The importance of soil characteristics in determining survival of first-year cottonwood seedlings in altered riparian habitats. Restoration Ecology 16:563-571.

Bormann, F.H., and G.E. Likens. 1979. Pattern and process in a forested ecosystem. Springer-Verlag, New York, NY. 262 pp.

Breshears, D.D., J.W.Nyhan, C.E. Heil, and B.P. Wilcox. 1998. Effects of woody plants on microclimate in a semiarid woodland: soil temperature and evaporation in canopy and intercanopy patches. International Journal of Plant Science 159:10101017.

Bussler, B.H., B.D. Maxwell, and K.J. Puettmann. 1995. Using plant volume to quantify interference in corn (Zea mays) neighborhoods. Weed Science 43:421-428.

Callaway, R.M. 1992. Effect of shrubs on recruitment of Quercus douglasii and Quercus lobata in California. Ecology 73:2118-2128.

Castro, J., R. Zamora, J.A. Hódar, and J.M. Gómez. 2002. Use of shrubs as nurse plants: A new technique for reforestation in Mediterranean Mountains. Restoration Ecology 10:297-305.

Castro, J., R. Zamora, J.A. Hódar, and J.M. Gómez, and L.Gómez-Aparicio. 2004. Benefits of using shrubs as nurse plants for reforestation in Mediterranean mountains: a 4-year study. Restoration Ecology 12 352-358.

Christensen, D.L., B.R. Herwig, D.E Schindler, and S.R. Carpenter. 1996. Impacts of lakeshore residential development on coarse woody debris in north temperate lakes. Ecological Applications 6:1143-1149.

Dong, S., C.F. Scagel, L. Cheng, L.H. Fuchigami, and P. Rygiewizc. 2001. Soil temperature and plant growth stage influences nitrogen uptake and amino acid concentration of apple during early spring growth. Tree Physiology 21:541-547.

Ehleringer, J.R., and D.R. Sandquist. 2006. Ecophysiological constraints on plant responses in a restoration setting. In Foundations of Restoration Ecology, ed. D.A. Falk, M.A. Palmer, and J.B. Zedler, 42-58 Washington D.C. Island Press. $364 \mathrm{pp}$. 
Elias, J.E., and M.W. Meyer. 2003. Comparisons of undeveloped and developed shorelands, northern Wisconsin, and recommendations for restoration. Wetlands 23:800-816.

Engle, S. and J.L. Pederson, Jr. 1998. The construction, aesthetics, and effects of lakeshore development: a literature review. Wisconsin Department of Natural Resources PUBL-SS-577-99.

France, R., R.Peters, and L. McCabe. 1998. Spatial relationships among boreal riparian trees, litterfall and soil erosion potential with reference to buffer strip management and coldwater fisheries. Ann. Bot. Fennici 35:1-9.

Frelich, L.E. 2002. Forest Dynamics and Disturbances Regimes. Cambridge University Press. $266 \mathrm{pp}$.

Gilbert, J.H., J.L. Wright, D.J. Lauten, and J.R. Probst. 1997. Den and rest-site characteristics of American Marten and Fisher in northern Wisconsin. In Martes: taxonomy, ecology, techniques, and management, pages 135-145. G. Proulx, H.N. Bryant, and P.M. Woodard, editors. Provincial Museum of Alberta, Edmonton, Alberta, Canada. 484 pp.

Gonzelez-Abraham, C.E., V.C. Radeloff, R.B. Hammer, T.J Hawbaker, S.I. Stewart, and M.K. Clayton. 2007. Building patterns and landscape fragmentation in northern Wisconsin, USA. Landscape Ecology 22: 217-230.

Gray, A.H., and T.A. Spies. 1997. Microsite controls on tree seedling establishment in conifer forest canopy gaps. Ecology 78:2458-2473.

Hagan, J.M., and S.L. Grove. 1999. Coarse woody debris. Journal of Forestry 97:6-11.

Harmon, M.E., J.F. Franklin, and F.J. Swanson. 1986. Ecology of course woody debris in temperate ecosystems. Advanced Ecological Research 15:133-302.

Henderson, C.L. 1987. Landscaping for wildlife. Minnesota Department of Natural Resources. Minnesota Bookstore. St. Paul, MN. 144 pp.

Heneghan, L., S.P. Miller, S. Baer, M.A. Callaham, Jr., J. Montgomery, M. PavoaZucermann, C.C. Rhoades, and S. Richardson. 2008. Integrating soil ecological knowledge into restoration management. Restoration Ecology 16: 608-617.

Hightshoe, G.L. 1988. Native trees, shrubs, and vines of urban and rural America. Van Nostrand Reinhold, New York. 819 pp.

Jaeger, R.G. 1980. Microhabitats of a terrestrial forest salamander. Copeia, 1980: 265-268. 
Maser, C., R.G. Anderson, K. Cromack, Jr., J.T. Williams, and R.E. Martin. 1979. Dead and down woody material. In Wildlife habitats in a managed forest-the Blue Mountains of Oregon and Washington, J.W. Thomas, ed., P. 78-95. USDA Agricultural Handbook, 553.

Macbeth, E.J. 1992. Protecting aesthetics and the visual resource of lakes. In Enhancing the states' lake management programs. North American Lake Management Society, Washington, D.C. 112 pp.

Maestre, F., S.Bautista, J. Cortina, and J. Bellot. 2001. Potential for using facilitation by grasses to establish shrubs on a semiarid degraded steppe. Ecological Applications 11:1641-1655.

Marburg, A.E, M.G. Turner, and T.K Kratz. 2006. Natural and anthropogenic variation in coarse wood among and within lakes. Journal of Ecology 94:558-568.

McComb, B.C. 2008. Wildlife habitat management: concepts and applications in forestry. CRC Press. $319 \mathrm{pp}$.

NRCS (Natural Resource Conservation Service). 1986. Soil survey of Vilas County. Unites States Department of Agriculture.

NRCS (Natural Resource Conservation Service). 2002. Wisconsin Biology Technical Note 1: Shoreland Habitat. NRCS. ftp://ftpfc.sc.egov.usda.gov/WI/technotes/biology-tn1.pdf

Radeloff, V.C., R.B. Hammer, P.R. Voss, A.E. Hagen, D.R. Field, and D.J. Mladdenoff. 2001. Human demographics trends and landscape level forest management in the northwest Wisconsin pine barrens. Forest Science 47:229-241.

Rasmussen, H.N., and D.F. Whigman. 1998. Importance of woody debris in seed germination of Tipularia discolor (Orchidaceae). American Journal of Botany $85: 829-834$

Reid, K.D., B.P. Wilcox, D.D. Breshears, and L. MacDonald. 1999. Runoff and erosion in a Pinon-Juniper woodland: influence of vegetation patches. Soil Sci. Soc. Am. J., 63:1869-1879.

Russell, E.W. 1973. Soil conditions and plant growth. Longman Group Limited, London, Great Britian. 849 pp.

Schnaiberg, J., J. Riera, M.G. Turner, and P.R. Voss. 2002. Explaining human settlement patterns in a recreational lake district: Vilas County, Wisconsin, USA. Environmental Management 30:24-34. 
Smith, W.R. 2008. Trees and shrubs of Minnesota: complete guide to species identification. The University of Minnesota Press, Minneapolis, MN. 703 pp.

Soper, J.H., and M.L. Heimburger. 1994. Shrubs of Ontario. Royal Ontario Museum. Toronto, Canada. 495 pp.

Stearns, F., and G.E. Likens. 2002. One hundred years of recovery of a pine forest in Northern Wisconsin. American Midland Naturalist. 148:2-19.

Stevens, Victoria. 1997. The ecological role of coarse woody debris: an overview of the ecological importance of CWD in B.C. forests. Res. Br., B.C. Min. For., Victoria, B.C. Work.

Tallmon, D.A., and L.S. Mills. 1994. Use of logs within home ranges of California Redbacked voles on a remnant forest. Journal of Mammalogy 74:97-101.

Ucitel, D., D.P Christian, and J.M. Graham. 2003. Vole use of course woody debris and implications for habitat and fuel management. Journal of Wildlife Management 67:65-72.

WDNR. 1996. Northern Wisconsin's Lakes and Shorelands: a report examining a resource under pressure. Wisconsin Department of Natural Resources. Madison, WI 53707.

WDNR. 2005. Wisconsin Lakes. Bureau of Fisheries and Habitat Management. PUBFH-800

Weiher, E., S.P. Poet, and K. Vos. 2003. Experimental Restoration of Lake Shoreland in Western Wisconsin. Ecological Restoration 21:186-190.

WinScanopy. 2005. WinSCANOPY 2005a for hemispherical image analysis. Regent Instruments Inc, Canada. 
Table 1.1. Abiotic data from three down woody material (DWM) coverage treatments. Data were collected during the summer of 2007 on Found and State House Lakes in Vilas County, Wisconsin prior to restoration efforts. No significant difference were found

\begin{tabular}{lccccc}
\hline & $\boldsymbol{N}$ & Max & Min & Mean & Std. Error \\
\hline Gap Fraction: & & & & & \\
0\% DWM Coverage & 10 & 65.8 & 30.0 & 42.1 & 4.3 \\
25\% DWM Coverage & 10 & 63.0 & 21.6 & 37.4 & 4.6 \\
50\% DWM Coverage & $9 *$ & 65.5 & 21.1 & 38.6 & 5.2 \\
Slope: & & & & & \\
0\% DWM Coverage & 10 & 30.0 & 8.0 & 16.5 & 2.8 \\
25\% DWM Coverage & 10 & 30.0 & 5.0 & 17.2 & 3.1 \\
50\% DWM Coverage & 10 & 30.0 & 8.0 & 16.7 & 2.8 \\
Aspect: & & & & & \\
0 \% DWM Coverage & 10 & 248.0 & 154.0 & 210.0 & 31.5 \\
25\% DWM Coverage & 10 & 248.0 & 154.0 & 210.0 & 31.5 \\
50\% DWM Coverage & 10 & 248.0 & 154.0 & 210.0 & 31.5 \\
\% Organic Matter: & & & & & \\
0\% DWM Coverage & 10 & 2.8 & 0.6 & 1.8 & 0.2 \\
25\% DWM Coverage & 10 & 3.7 & 0.5 & 2.1 & 0.3 \\
50\% DWM Coverage & 10 & 2.4 & 0.1 & 1.7 & 0.2 \\
\hline
\end{tabular}

* Missing one digital hemispherical photograph. 
Table 1.2. Pre-down woody material (DWM) addition soil temperature variables ( $\alpha$ $=0.05)$. Data were collected during the summer of 2007 on Found and State House

Lakes in Vilas County, Wisconsin prior to restoration efforts.

\begin{tabular}{|c|c|c|c|c|c|c|c|}
\hline Month & Variable & Treatment & $N$ & Mean & Std. Err. & $F$ & $P$ \\
\hline \multirow[t]{12}{*}{ June } & Ave. Temp. & & & & & $F_{2,17}=0.526$ & 0.600 \\
\hline & & $0 \% \mathrm{DWM}$ & 6 & 19.8 & 1.0 & & \\
\hline & & $25 \%$ DWM & 7 & 19.4 & 0.6 & & \\
\hline & & $50 \%$ DWM & 7 & 20.5 & 0.7 & & \\
\hline & Max. Temp. & & & & & $\boldsymbol{F}_{2,17}=0.460$ & 0.639 \\
\hline & & $0 \% \mathrm{DWM}$ & 6 & 24.6 & 1.8 & & \\
\hline & & $25 \%$ DWM & 7 & 23.2 & 0.9 & & \\
\hline & & $50 \%$ DWM & 7 & 24.7 & 1.2 & & \\
\hline & Temp.Var. & & & & & $\boldsymbol{F}_{2,17}=0.194$ & 0.825 \\
\hline & & $0 \% \mathrm{DWM}$ & 6 & 8.0 & 1.3 & & \\
\hline & & $25 \% \mathrm{DWM}$ & 7 & 7.4 & 0.8 & & \\
\hline & & $50 \%$ DWM & 7 & 8.4 & 1.4 & & \\
\hline \multirow[t]{12}{*}{ July } & Ave. Temp. & & & & & $\boldsymbol{F}_{2,20}=0.252$ & 0.780 \\
\hline & & $0 \% \mathrm{DWM}$ & 8 & 19.8 & 0.9 & & \\
\hline & & $25 \%$ DWM & 7 & 19.3 & 0.6 & & \\
\hline & & $50 \%$ DWM & 8 & 19.9 & 0.6 & & \\
\hline & Max. Temp. & & & & & $\boldsymbol{F}_{2,20}=0.313$ & 0.735 \\
\hline & & $0 \% \mathrm{DWM}$ & 8 & 23.9 & 1.5 & & \\
\hline & & $25 \%$ DWM & 7 & 22.8 & 0.9 & & \\
\hline & & $50 \%$ DWM & 8 & 23.8 & 1.0 & & \\
\hline & Temp.Var. & & & & & $\boldsymbol{F}_{2,20}=0.152$ & 0.860 \\
\hline & & $0 \% \mathrm{DWM}$ & 8 & 6.8 & 0.9 & & \\
\hline & & $25 \%$ DWM & 7 & 6.3 & 0.6 & & \\
\hline & & $50 \%$ DWM & 8 & 6.9 & 1.1 & & \\
\hline \multirow[t]{12}{*}{ August } & Ave. Temp. & & & & & $\boldsymbol{F}_{2,12}=0.567$ & 0.582 \\
\hline & & $0 \% \mathrm{DWM}$ & 4 & 21.7 & 0.5 & & \\
\hline & & $25 \%$ DWM & 6 & 21.2 & 0.3 & & \\
\hline & & $50 \%$ DWM & 5 & 21.3 & 0.3 & & \\
\hline & Max. Temp. & & & & & $\boldsymbol{F}_{2,12}=1.230$ & 0.327 \\
\hline & & $0 \% \mathrm{DWM}$ & 4 & 26.2 & 0.4 & & \\
\hline & & $25 \%$ DWM & 6 & 24.9 & 0.7 & & \\
\hline & & $50 \%$ DWM & 5 & 25.7 & 0.6 & & \\
\hline & Temp.Var. & & & & & $\boldsymbol{F}_{2,12}=1.053$ & 0.379 \\
\hline & & $0 \% \mathrm{DWM}$ & 4 & 7.6 & 0.4 & & \\
\hline & & $25 \%$ DWM & 6 & 6.2 & 0.6 & & \\
\hline & & $50 \%$ DWM & 5 & 7.3 & 0.9 & & \\
\hline
\end{tabular}


Table 1.3. Post-down woody material (DWM) addition soil temperature variables $(\alpha=0.05)$. Data were collected during the summer of 2008 on Found and State House Lakes in Vilas County, Wisconsin after restoration efforts and the addition of DWM.

\begin{tabular}{|c|c|c|c|c|c|c|c|}
\hline Month & Variable & Treatment & $N$ & Mean & Std. Err. & $\boldsymbol{F}_{2,27}$ & $P$ \\
\hline \multirow{12}{*}{ June } & Ave. Temp. & & & & & 1.780 & 0.188 \\
\hline & & $0 \%$ DWM & 10 & 17.0 & 0.4 & & \\
\hline & & $25 \%$ DWM & 10 & 15.9 & 0.4 & & \\
\hline & & $50 \%$ DWM & 10 & 16.2 & 0.4 & & \\
\hline & Max. Temp. & & & & & 3.700 & 0.038 \\
\hline & & $0 \% \mathrm{DWM}$ & 10 & 21.4 & 0.8 & & \\
\hline & & $25 \%$ DWM & 10 & 18.9 & 0.7 & & \\
\hline & & $50 \%$ DWM & 10 & 19.1 & 0.7 & & \\
\hline & Temp.Var. & & & & & 6.506 & 0.005 \\
\hline & & $0 \% \mathrm{DWM}$ & 10 & 7.2 & 0.6 & & \\
\hline & & $25 \%$ DWM & 10 & 4.9 & 0.4 & & \\
\hline & & $50 \%$ DWM & 10 & 4.9 & 0.5 & & \\
\hline \multirow[t]{12}{*}{ July } & Ave. Temp. & & & & & 2.285 & 0.121 \\
\hline & & $0 \% \mathrm{DWM}$ & 10 & 20.1 & 0.5 & & \\
\hline & & $25 \%$ DWM & 10 & 19.0 & 0.5 & & \\
\hline & & $50 \%$ DWM & 10 & 19.0 & 0.4 & & \\
\hline & Max. Temp. & & & & & 6.050 & 0.007 \\
\hline & & $0 \%$ DWM & 10 & 25.1 & 0.8 & & \\
\hline & & $25 \% \mathrm{DWM}$ & 10 & 22.2 & 0.8 & & \\
\hline & & $50 \% \mathrm{DWM}$ & 10 & 22.0 & 0.6 & & \\
\hline & Temp.Var. & & & & & 11.894 & $<0.001$ \\
\hline & & $0 \% \mathrm{DWM}$ & 10 & 8.2 & 0.6 & & \\
\hline & & $25 \%$ DWM & 10 & 5.4 & 0.5 & & \\
\hline & & $50 \%$ DWM & 10 & 5.0 & 0.4 & & \\
\hline \multirow[t]{12}{*}{ August } & Ave. Temp. & & & & & 3.141 & 0.059 \\
\hline & & $0 \% \mathrm{DWM}$ & 10 & 19.7 & 0.4 & & \\
\hline & & $25 \%$ DWM & 10 & 18.5 & 0.5 & & \\
\hline & & $50 \%$ DWM & 10 & 18.3 & 0.3 & & \\
\hline & Max. Temp. & & & & & 9.042 & $<0.001$ \\
\hline & & $0 \% \mathrm{DWM}$ & 10 & 25.0 & 0.7 & & \\
\hline & & $25 \%$ DWM & 10 & 21.8 & 0.8 & & \\
\hline & & $50 \%$ DWM & 10 & 21.1 & 0.5 & & \\
\hline & Temp.Var. & & & & & 14.658 & $<0.001$ \\
\hline & & $0 \% \mathrm{DWM}$ & 10 & 9.0 & 0.6 & & \\
\hline & & $25 \%$ DWM & 10 & 5.8 & 0.6 & & \\
\hline & & $50 \%$ DWM & 10 & 5.1 & 0.3 & & \\
\hline
\end{tabular}


Table 1.4. Ground cover species survival rates for one year (2007-2008) after planting in three woody material (DWM) coverage treatments. Survival rates were recorded from Found and State House Lakes' restoration projects in Vilas County, Wisconsin.

\begin{tabular}{ccccc}
\hline & \multicolumn{4}{c}{ DWM Coverage (\%) } \\
Species & $\mathbf{0}$ & $\mathbf{2 5}$ & $\mathbf{5 0}$ & Total \\
\hline Anaphalis margaritacea & $96 \%$ & $98 \%$ & $92 \%$ & $\mathbf{9 5 . 3 \%}$ \\
Aster marcophyllus & $96 \%$ & $96 \%$ & $96 \%$ & $\mathbf{9 6 . 0} \%$ \\
Monarda fistulosa & $92 \%$ & $82 \%$ & $82 \%$ & $\mathbf{8 5 . 3 \%}$ \\
Schizachyrium scoparium & $90 \%$ & $80 \%$ & $98 \%$ & $\mathbf{8 9 . 3 \%}$ \\
Waldstenia fragaroides & $100 \%$ & $96 \%$ & $98 \%$ & $\mathbf{9 8 \%}$ \\
\hline Total & $\mathbf{9 4 . 8 \%}$ & $\mathbf{9 5 . 4 \%}$ & $\mathbf{9 3 . 2 \%}$ & $\mathbf{9 2 . 8 \%}$ \\
\hline
\end{tabular}

Table 1.5. The percent change of canopy volume for five ground cover species relative to three treatments of down woody material (DWM) coverage. Data were recorded in 2008 from Found and State House Lakes in Vilas County, Wisconsin.

\begin{tabular}{|c|c|c|c|c|c|}
\hline Species & $N$ & Max & Min & Mean & Std. Error \\
\hline \multicolumn{6}{|c|}{$\begin{array}{l}\text { Anaphalis margaritacea } \\
(n=132)\end{array}$} \\
\hline $0 \%$ DWM Coverage & 10 & 269.4 & 3.6 & 49.4 & 26.1 \\
\hline $25 \%$ DWM Coverage & 10 & 311.3 & 11.6 & 61.2 & 29.0 \\
\hline $50 \%$ DWM Coverage & 10 & 826.9 & 7.0 & 110.7 & 80.0 \\
\hline \multicolumn{6}{|l|}{$\begin{array}{l}\text { Aster marcophyllus } \\
(n=135)\end{array}$} \\
\hline $0 \%$ DWM Coverage & 10 & 66.3 & 4.9 & 26.1 & 6.1 \\
\hline $25 \%$ DWM Coverage & 10 & 78.1 & 8.4 & 30.7 & 6.6 \\
\hline $50 \%$ DWM Coverage & 10 & 528.2 & 9.8 & 106.9 & 50.6 \\
\hline \multicolumn{6}{|l|}{$\begin{array}{l}\text { Monarda fistulosa } \\
(n=128)\end{array}$} \\
\hline $0 \%$ DWM Coverage & 10 & 148.2 & 3.2 & 29.5 & 13.9 \\
\hline $25 \%$ DWM Coverage & 10 & 148.8 & 1.4 & 31.1 & 14.0 \\
\hline $50 \%$ DWM Coverage & 10 & 91.5 & 3.6 & 27.2 & 10.7 \\
\hline \multicolumn{6}{|l|}{$\begin{array}{l}\text { Schizachyrium } \\
\text { scoparium } \\
(n=102)\end{array}$} \\
\hline $0 \%$ DWM Coverage & 10 & 5256.4 & 102.6 & 871.0 & 493.6 \\
\hline $25 \%$ DWM Coverage & 9* & 8083.2 & 61.0 & 1458.6 & 858.0 \\
\hline $\begin{array}{l}50 \% \text { DWM Coverage } \\
\text { Waldstenia fragaroide } \\
(n=144)\end{array}$ & $9 *$ & 19051.6 & 59.8 & 3536.6 & 2007.3 \\
\hline $0 \%$ DWM Coverage & $9 *$ & 1.8 & -0.7 & -0.1 & 0.2 \\
\hline $25 \%$ DWM Coverage & 10 & 2.8 & -0.5 & 0.2 & 0.3 \\
\hline $50 \%$ DWM Coverage & $8 *$ & 10.7 & -0.3 & 1.4 & 1.1 \\
\hline
\end{tabular}

* Species were missing from the DWM plots do to mortality or missing plants during the initial measurements in May 2008. 


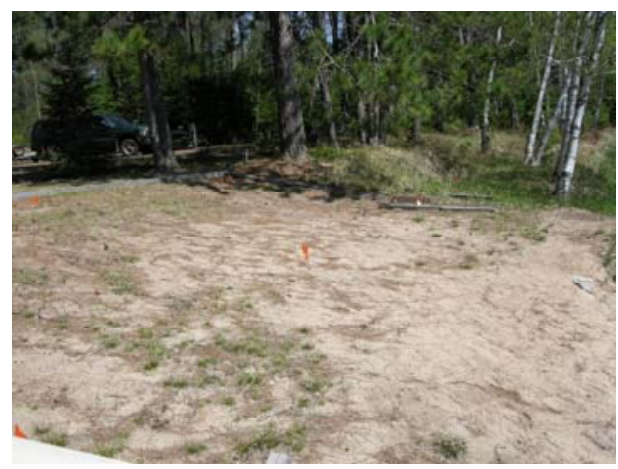

(a)

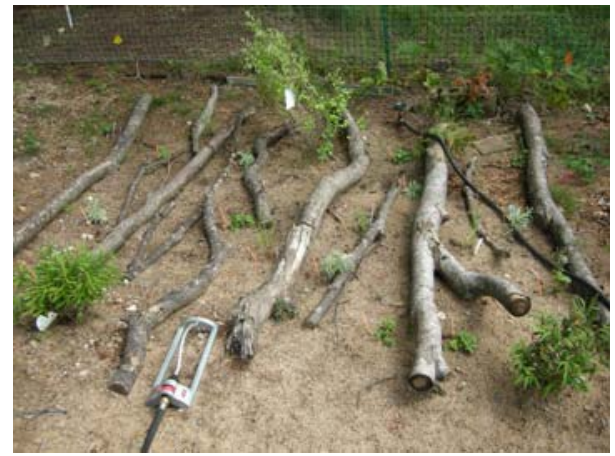

(b)

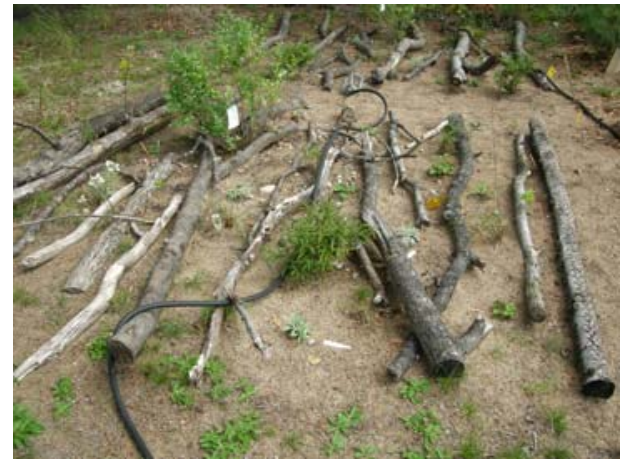

(c)

Figure 1.1 Represents experimental plots with woody material in place: (a) $0 \%$ woody material coverage, (b) $25 \%$ woody material coverage, (c) $50 \%$ woody material coverage. 


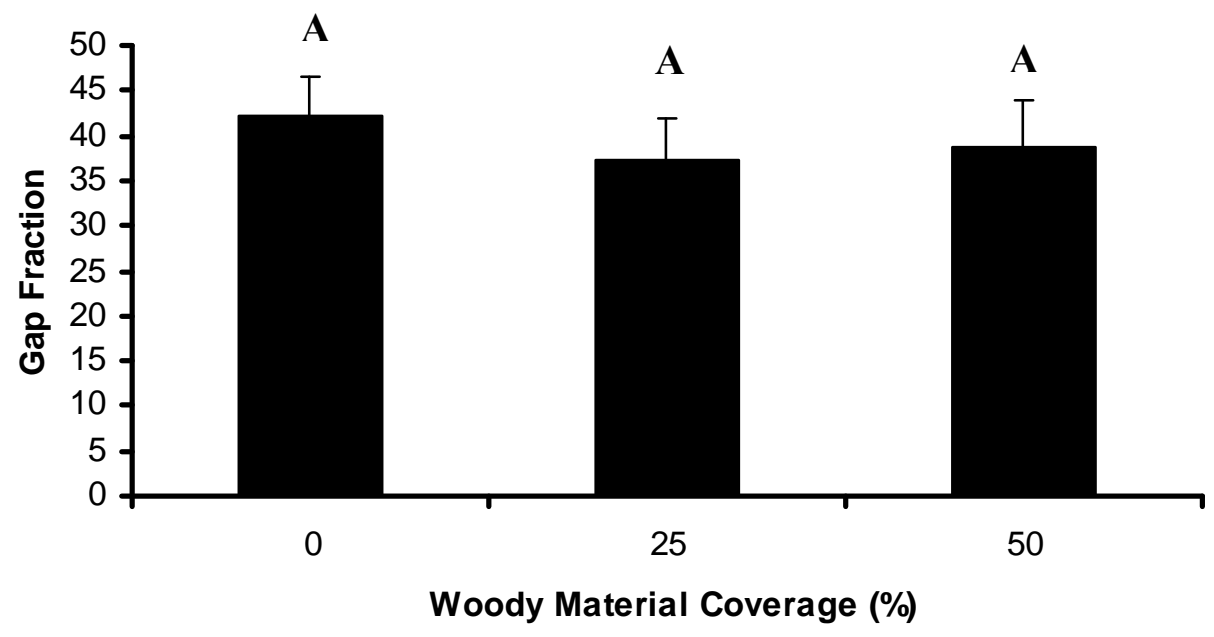

Figure 1.2 Mean gap fraction and standard error for each treatment of percent down woody material (DWM) coverage. Data was taken prior to restoration efforts and the addition of DWM on Found and State House Lakes, Vilas County, Wisconsin. There was no significant differences between treatments $(H=1.252$, df $=2, P=0.535$ ). Bar columns with the same letter are not significantly different by Holm-Sidak Pairwise Multiple Comparison Procedures $(P=<0.001)$ 

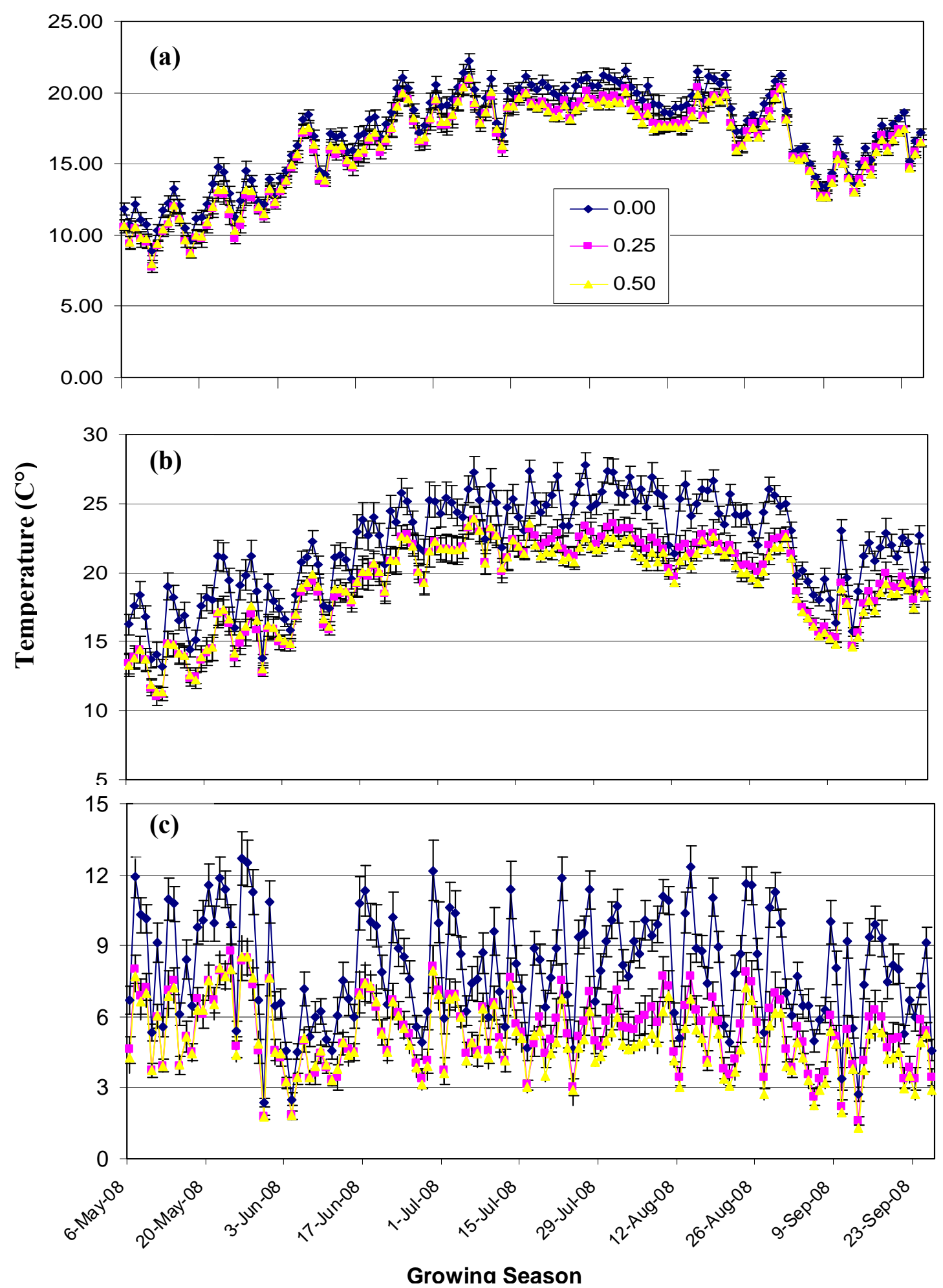

Figure 1.3. Three soil temperature variables (a) mean daily, (b) mean daily maximum, and (c) mean daily difference between high and low temperatures measured during the 2008 growing season with standard error bars. Temperatures were compared between three different percent coverage of down woody material on Found and State House Lakes, Vilas County, Wisconsion 


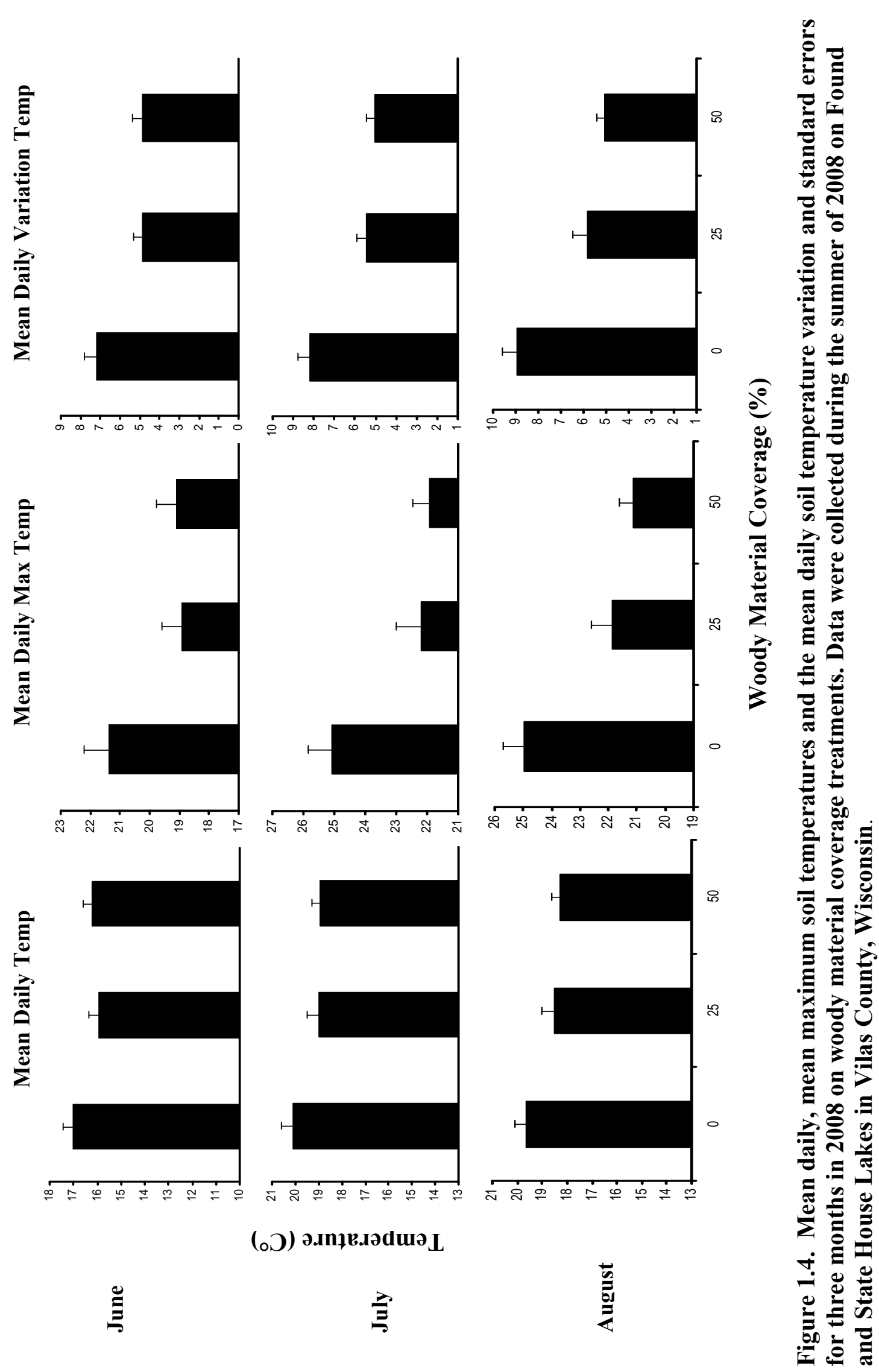


(a)

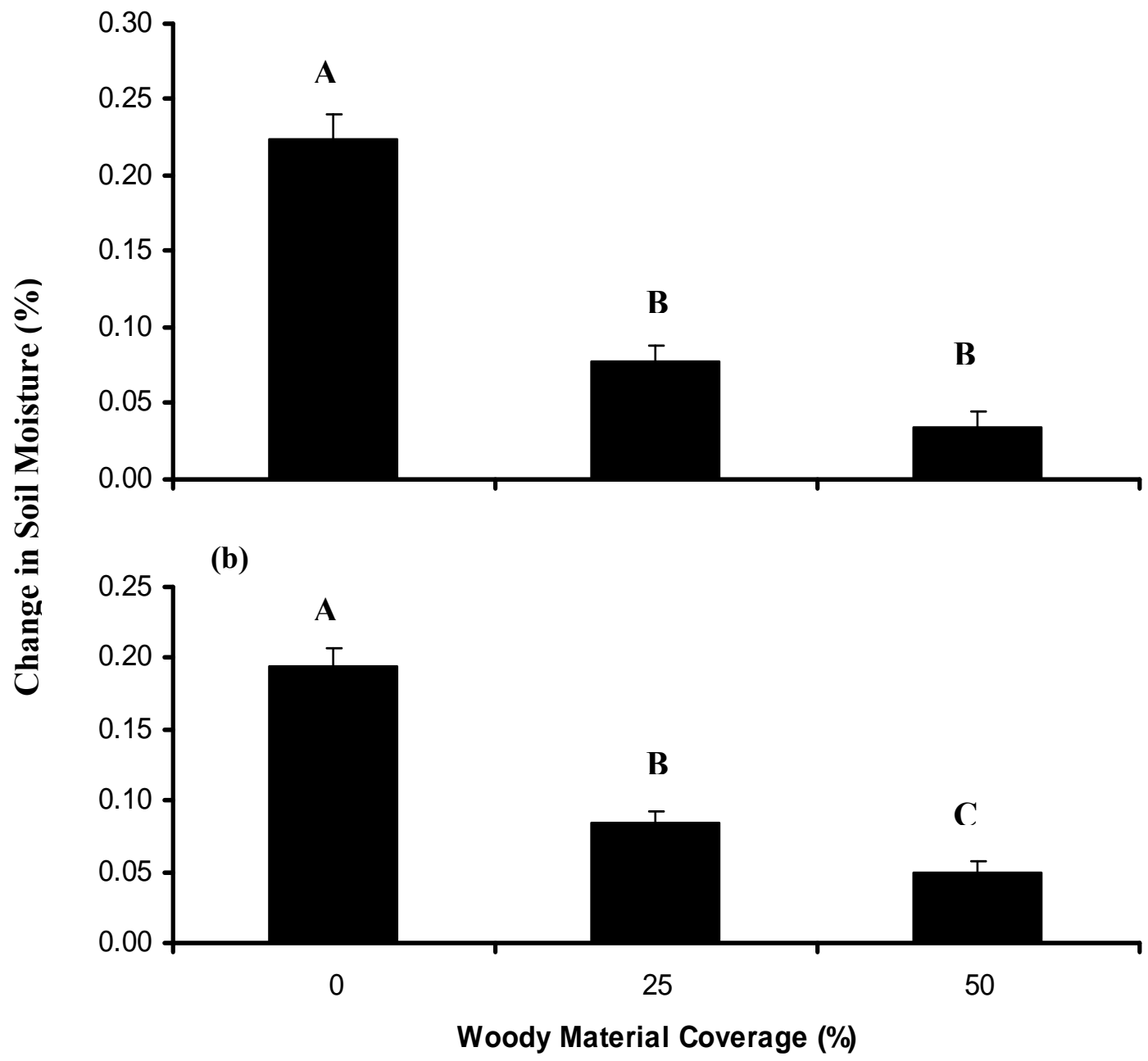

Figure 1.5. Mean percent change of soil moisture content from 12 hours to 36 hours after watering from July (a) and August (b) 2008 on three woody material coverage treatment. Data was collected from restoration projects on Found and State House Lakes, Vilas County, Wisconsin. Bar columns with the same letter are not significantly different by Holm-Sidak Pairwise Multiple Comparison Procedures (P $=<\mathbf{0 . 0 0 1 )}$ 


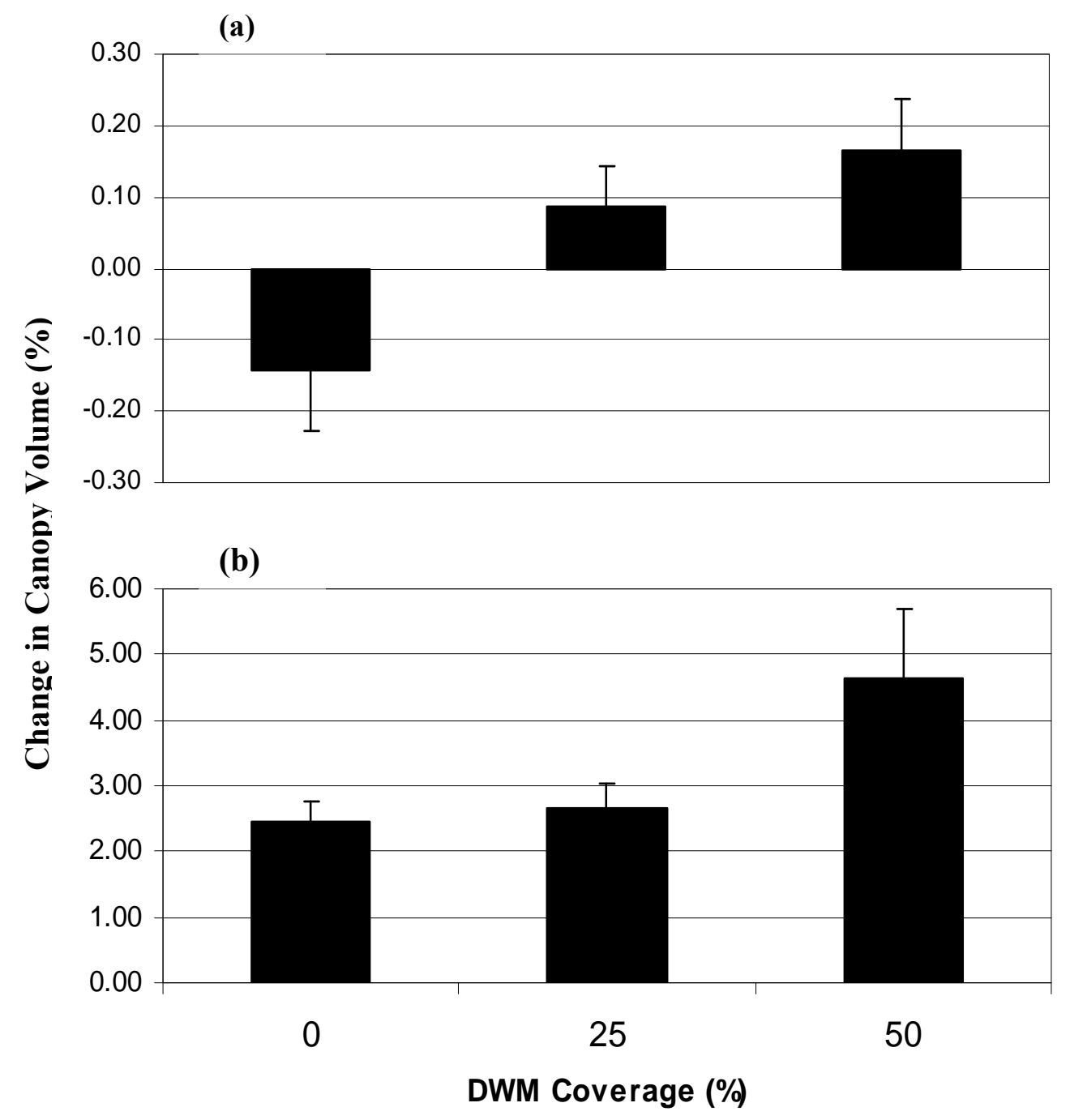

Figure 1.6. Percent change in canopy volume for snowberry (a) and sweet fern (b) over a one year period. Data collected on Found and State House Lakes Vilas County, Wisconsin from August 2007 to 2008. 


\title{
CHAPTER 2
}

\section{RESIDENTIAL DEVELOPMENT IMPACT ON MAMMALIAN DIVERSITY ALONG LAKESHORES IN NORTHERN WISCONSIN}

\begin{abstract}
Residential development has expanded across North America at a dramatic rate which reduces biodiversity. The upper mid-west has experienced a high percentage of development around lake shores. Recent studies have documented negative effects on the local floral and fauna but little is known of the effect residential development has on the mammal community. I investigated the effect residential development is having on the local mammal community on lakeshores. I conducted snow track surveys on ten pairs of low-and high-development lakes in Vilas County, Wisconsin in 2008. Twelve remote cameras were deployed on four lakes in the area. The results suggest that a higher diversity of mammals, especially carnivores, were detected on low-development lakes. Coyotes were the most numerous species detected with the majority encountered on lowdevelopment lakes. White-tailed deer and red fox were detected more on higherdevelopment than low-development lakes.
\end{abstract}

\section{Introduction}

Rural landscapes in the Midwest have experienced dramatic changes in recent decades due to residential development (Radeloff et al. 2005). Residential development in rural landscapes causes fragmentation and the loss of wildlife habitat (Theobald et al. 1997) and thus poses a serious threat to biodiversity (Wilcove et al. 1998, Czech et al. 
2000). People are inclined to construct primary or secondary homes in and around natural areas because they provide a natural environment, opportunities for recreation, and scenery (Schnaiberg et al. 2002). Freshwater ecosystems have attracted people and development for centuries (Naiman 1996, Riera et al. 2001). In northern Wisconsin, residential development has increased over $200 \%$ along lakeshores in recent decades (WDNR 1996, Radeloff et al. 2001, Gonzales-Abraham et al. 2007).

Residential development often results in the removal of vegetation structure along shorelines (Elias and Meyer 2003). Wildlife can be affected directly or indirectly by removal of vegetation structure. Recent studies comparing low- and high-development lakes in Vilas County, Wisconsin documented declines in the floral and fauna on these lake shorelines For example, species composition of breeding birds differed significantly (Lindsay et al. 2002), abundance of green frogs was substantially lower (Woodford and Meyer 2003), and vegetation structure and composition in riparian and littoral zones were dramatically different (Elias and Meyer 2003) along low- and high-residential development lakeshores. However, no known studies investigated the effect of housing development on the mammal community in this region, and in particular on medium and large mammals.

Crooks (2002) reported that certain carnivore species are sensitive to human habitat fragmentation and the presence and abundance of carnivores can reflect the health of an ecosystem. Carnivores play an important role in structuring communities (Eisenberg 1989, Oehler and Litvaitis 1996, Crooks and Soulé 1999, Schmitz et al. 2000). For example, in southern California the occurrence of bobcats (Lynx rufus) and coyotes 
(Canis lantrans) were less common in landscapes with greater residential development (Crooks 2002). The absence of carnivores in an ecosystem can have a significant impact on the relative abundance of herbivores and small predators. In some cases, the loss of larger carnivores has allowed one or two species may dominate a community and further reduces biodiversity (Crooks and Soulé 1999, Berger et al. 2001, Hebblewhite et al. 2005). Thus, maintenance of carnivore species becomes an important consideration in managing healthy ecosystems (Eisenberg 1989). The management of natural habitats for carnivore is becoming one of the greatest challenges for conservation biologists and policy makers in North America (Noss et al. 1996).

Certain carnivore species are among the most elusive animals in the world, and many are nocturnal and secretive, live in low densities, and have large home ranges which make them difficult to detect and monitor (Hoffman 1996). I used two noninvasive techniques to determine the presence of mammalian species on lakeshores in northern Wisconsin. Winter snow track surveys were used on ten pairs of low- and highdevelopments lakes in Vilas County during the winter of 2008. In addition, I deployed and monitored 12 remote digital cameras on two pairs of low- and high-development lakes in Vilas County from June 2007 to August 2008. The latter are currently undergoing restoration of native vegetation along a 35 foot shoreline buffer. I chose these two techniques because certain species have different seasonal behavior patterns. For example, black bears (Ursus americanus), and raccoons (Procyon lotor) hibernate though the winter months and may not be detected by snow track surveys. Certain canid species that are wary of human scent may avoid cameras. In addition, vegetation and 
seasonality can produce species-specific differences in detectability, and body size characteristics of species may influence detection (O’Connell et al. 2006).

The objectives of my research were to: (1) determine if residential development on lakeshores is related to mammalian diversity and relative abundance, (2) provide baseline data for long-term monitoring of medium and large mammals and, (3) provide baseline data for current lakeshore restoration projects. I hypothesized that lakeshores with higher-development will have fewer mammal species than lakeshore with lowerdevelopment.

\section{Methods}

\section{Study area}

This study was conducted in Vilas County, Wisconsin, which is within the Northern Highland Lake District. Vilas County encompasses a 2,636 $\mathrm{km}^{2}$ area along the states northern border with the Upper Peninsula of Michigan. Vilas County contains 1320 pitted outwash glacial lakes ranging in size from 0.1 to $>1500$ ha and covering $16 \%$ of the county's area (WDNR 2005), and 53\% of the area is privately owned. (Schnaiberg et al. 2002). The land cover is a mixture of bogs, northern wet forest, boreal forest, and northern dry to northern xeric forest (Curtis 1959). Vilas County has undergone extreme residential development in recent decades with the majority of development occurring within $100 \mathrm{~m}$ of a lake (Schnaiberg et al. 2002).

Study lakes were systematically chosen from the University of Wisconsin, Trout Lake Limnology BioComplexity project data base (http://biocomplexity.limnology.wisc.edu). I matched ten pairs of lakes according to 
similar surface area and lake type (i.e. drainage, seepage, spring fed) (see Woodford and Meyer 2003); one lake in each pair had a high density $(\geq 10$ houses $/ \mathrm{km}$, mean $=23.45 \pm$ 2.69) of shoreline development and the other lake had a low density $(<10$ houses $/ \mathrm{km}$, mean $=2.10 \pm 0.64)$ of shoreline development (Table 2.1)

\section{Snow track surveys}

Observing tracks in the snow is a traditional and often a reliable technique for determining carnivore presence, abundance, distribution, behavior, and habitat use (Heinemeyer et al. 2008). Carnivore species can be identified by characteristics of tracks, gait patterns, stride and straddle (Halfpenny 1986), and snow reveals a continuous record of animal movement between successive snowfalls (Halfpenny et al. 1995). This snow tracking technique is used to survey and monitor carnivore populations throughout the region (Wydeven et al. 2004, 2007). Snow tracking is non-invasive and does not alter natural behavior of the target species. In addition, this technique seldom requires specialized equipment and is usually less costly relative to other more intensive techniques.

I conducted winter snow track surveys during January - February 2008 on all 20 lakes. Surveys were conducted 48 to 96 hours following snowfalls of $\geq 2.5 \mathrm{~cm}$, at temperatures above $-17^{\circ} \mathrm{C}$, and with winds less than $10 \mathrm{mph}$. Transects started at a point of lake access (e.g. boat landing) and traveled (via snow-shoes or cross-country skis) 1500 linear meters on the frozen lake surface, along the shoreline. I identified all carnivore species according to methods described by Halfpenny (1986). If tracks were not immediatley identified, I backtracked the trail to suitable topography to take 
measurements and determine the species. I recorded all carnivore tracks encountered 10 $m$ on each side of the transect. In addition, I tallied encounters with non-carnivore species: micro-tine rodents, Snowshoe Hare (Lepus americanus), Eastern Cottontail Rabbit (Sylvilagus floridanus), Sciuridae species, White-tailed deer (Odocoileus virginianus), and Domestic Dog (Canis familiarus). I developed the following index to categorize the abundance of these species: 0 If no tracks were detected, $1=1$ to 5 tracks, $2=6$ to 10 tracks, $3=>10$ tracks for each transect (Table 2.2). Both lakes in a pair were surveyed sequentially the same day with no more than 30 min between surveys periods.

\section{Remote Cameras}

Remote cameras have been used in wildlife research to address a variety of questions. The data collected by cameras for this analysis are from two high-development lakes currently undergoing restoration of vegetation along the shoreline and their lowdevelopment pairs (Table 2.1). This information should be interpreted as baseline data for the long term research project.

Twelve motion sensor, digital cameras (Cuddeback ${ }^{\mathrm{TM}}$ Expert, Non Typical, Inc., Park Falls, Wisconsin) with a $3 / 4$ second trigger speed were placed on the subset of four paired lakes, two low- and two high-development with six cameras deployed on lowdevelopment and six cameras deployed on high-development lakes. Camera sites were determined by dividing the shoreline into $50 \mathrm{~m}$ segments using GIS (Geographic Information System) software and labeled by numbers $(1,2,3, \ldots .$.$) . Segments were$ randomly picked such that until cameras were placed at least $\geq 1 \mathrm{~km}$ apart to increase independence. The number of cameras per lake was determined by the length of the 
shoreline such that $2 \mathrm{~km}$ of shoreline contained one camera for example, if the shoreline was $4 \mathrm{~km}$ in length, then two cameras were used on that lake. Cameras were moved if people disturbed them. There were 11 camera sites on the high development lakes and eight camera sites on low-development lakes.

Cameras were placed within $10 \mathrm{~m}$ of the shoreline, positioned toward a game trail when present, and attached to a tree $50 \mathrm{~cm}$ above the ground. On high-development lakes, cameras were placed in relatively unaltered area (i.e. intact natural vegetation). A cotton ball saturated with lure (shellfish oil) was placed inside an empty plastic, perforated film canister and hung in a tree within $5 \mathrm{~m}$ of a camera. Cameras were programmed to take photos $24 \mathrm{hr} /$ day, pause for one minute intervals between events, and to record date and time of event on each image. I checked batteries and compact flash cards every 2 to 4 weeks.

\section{Data analyses}

\section{Snow track survey}

I calculated Shannon's Index of species diversity $\left(H^{\prime}\right)$ (Magurran 2004) for each lake within a group of ten categorized as low- or high-development. I used a $t$-test to test the null hypothesis that low- and high-development lakes have equal $H^{\prime}$ indices of diversity. The abundance indices for non-carnivore species were averaged by treatment and interpreted by relative abundance (Table 2.2). I used a $t$-test to compare mean relative abundance of non-carnivore species between low- and high-development lakes. For $t$ tests, I determined if all test assumptions (normality and equal variance) were met. The Kolmogorov-Smirnov test was used to test for normal distribution of the samples. Data 
that violated assumptions were transformed using natural logarithms. When transformation of variables was unsuccessful in producing a normal distribution, I used the nonparametric Mann-Whitney Rank Sum $U$-test. Analyses were conducted using SigmaStat 3.5 software (Systat Software Inc.2006) and significance levels were set at $\alpha=$ 0.05 .

\section{Remote Cameras}

I calculated rate of occurrence (number of events/camera nights) for each species and at each camera location and calculated the mean for each type of development (O'Connell et al. 2006). I defined an event as a single species detection within a 24 hour period. Twelve cameras were deployed from June 12, 2007 to August 31, 2008 for a total of 5,700 camera nights. I excluded the data collected in the months of January and February 2008 because extreme cold temperatures and blowing drifting snow rendered some cameras inoperable.

\section{Results}

\section{Snow track survey}

I recorded 83 encounters of nine furbearer species across all lakes sampled $(n=20)$. Five of the nine species were detected exclusively on low-development lakes (Table 2.3). Sixty-eight individual track detections accounted for $92 \%$ of all individuals recorded on low-development lakes, and 15 detections accounted for $8 \%$ of all individuals recorded on high-development lakes. Coyotes were the most encountered species $(n=34)$ across all lakes. Red fox (Vulpes vulpes) accounted for 14 encounters and nine individuals were recorded on high-development lakes. Mink encounters were four times higher on low- 
development than high-development lakes (Table 2.3). Shannon's Index of diversity was significantly higher on low-development $($ mean $=1.974 \pm 0.438)$ than on highdevelopment lakes $($ mean $=0.277 \pm 0.113)(t=3.497, \mathrm{df}=9, P=0.007)$.

For non-carnivores, white-tailed deer were abundant on high-development lakes with encounters on all of the high-development lakes, but were found to be uncommon being detected on only $50 \%$ of low development lakes. Snowshoe hare and eastern cottontail rabbits were significantly different to the type of development. Hares were detected on $70 \%$ of low-development lakes, while cottontails were recorded on $90 \%$ of high-developments lakes, both species were significantly different. Domestic dogs were considered common on high-development while rare on low-development lakes. There was no significant difference for Sciuridae spp. and micro-tine rodents (Table 2.4).

\section{Remote Cameras}

Nine carnivore species were detected by cameras $(n=12)$ across all lakes sampled $(n=$ 4). Beaver (Castor canadensis), wolf, and fisher were exclusively photographed only on low-development lakes (Figure 2.2). Rate of occurrence for raccoon was approximately 2.5 times higher on high-development $($ mean $=0.048$ individual $/$ camera night \pm 0.036$)$ than on low-development lakes (mean $=0.019$ individual/camera night \pm 0.012 ). Red fox rate of occurrence was nearly twice as high on high-development lakes (mean individual $/$ camera night $=0.005 \pm 0.003)$ than on low-development lakes $($ mean $=0.003$ individual/camera night \pm 0.002 ). Rate of occurrence for domestic dog was over four times higher on high-development $($ mean $=0.037$ individual/camera night \pm 0.019$)$ than 
low-development lakes (mean $=0.009$ individual/camera night \pm 0.004$)$. Wolf and black bear occurrence was extremely low on all lakes sampled (Figure 2.2).

For non-carnivore species, white-tailed deer were detected more than 3 times more frequently on high-development $($ mean $=0.20$ individual/camera night \pm 0.09 ) than lowdevelopment lakes $($ mean $=0.06$ individual/camera night \pm 0.02$)($ Figure 2.3). Snowshoe hare, Sciuridae species, and eastern cottontail rabbit had low occurrence rates on all lakes. Eastern cottontail rabbits were not detected on low-development lakes. Sciuridae species had similar rates of occurrence on both types of lakes, and no micro-tine rodents were detected by remote cameras (Figure 2.4).

\section{Discussion}

These results suggest that mammal diversity and species richness were higher on lowdevelopment than high-development lakes. Many studies have investigated the effect of residential development on mammal presence and abundance relative to patch size and isolation (Crooks 2002), trophic cascades (Crooks and Soulé 1999, Hebblewhite et al. 2005), species interactions (Gosselink et al. 2003, McDonald et al. 2008) and wildlife habitat (Theobald et al. 1997). However, few studies have investigated the effect on mammal diversity on lake riparian areas relative to residential development. In one of the few studies, Racey and Euler (1982) found a decrease in small mammal diversity with increasing development on lakeshores in Ontario, Canada. However, their study was conducted on lakes with smaller seasonal cottages represented the type of development and where extreme habitat alternation was uncommon (Robertson and Flood 1980). 
Coyotes were by far the most common detected species recorded on lowdevelopment lakes, and bobcats were exclusively detected on low-development lakes during the snow tracking surveys. This suggests that these species may be sensitive to residential development or the many landscape and stand level changes associated with residential development as reported by Crooks (2002). Winter track surveys conducted by WDNR throughout the northern third of Wisconsin also found that coyotes were the most frequently encountered carnivore species (Wydeven et al. 2004, 2007). In addition, Wydeven et al. (2007) reported a two-fold increase in coyote detections between 2004 and 2007 winter track survey. Historical records suggests that coyotes were common to abundant throughout Wisconsin in the late 1800s and early 1900s but they were considered vermin and thus were hunted vigorously resulting in declining populations through the mid-1900s (Jackson 1961). Currently, coyotes have become more common in the northern half of the Wisconsin (Fruth 1986) as a reflection of increasing populations throughout North America (Voight and Berg 1987, Gompper 2002).

Coyotes have adapted to suburban and urban landscapes across North American (Gompper 2002, Gerht 2004, Markovchick-Nicholis et al. 2008) and yet my data suggests that they avoid high-development lakes in northern Wisconsin even while they are ubiquitous across the region (Wydeven et al. 2007). Gehrt (2007) postulated that coyotes will avoid humans, both temporally and spatially, while still living in the immediate area. My low detection rate of coyotes on high-development lakes suggests that coyotes, like most secretive mammals, prefer brushy habitat with tall vegetation (Fruth 1986). The park-like structure near shorelines on high-development lakes (Elias 
and Meyer 2003) may be the reason for lower coyote use and no detections of fisher and bobcat. Both fisher and bobcat prefer relatively large contiguous low conifer cover in the winter (Buskirk and Powell 1984, Lovallo and Anderson 1996) which is absent on the high-development lakes (Elias and Meyer 2003).

Coyote and red fox rate of occurrence at camera sites showed a similar pattern to that of snow track surveys for low- and high-development lakes. However, the number of total coyote camera detections was substantial lower than the total for snow track surveys. This may be due to the fact that alpha coyotes are able to avoid cameras (Séquin et al. 2003), the characteristics of camera location will influence the number of photocaptures (Séquin et al. 2007), and the small sample size of lakes.

Red foxes and coyotes can be sympatric (McDonald et al. 2008) but the smaller canid usually avoids coyotes by locating its territory on the periphery of coyote territories (Voigt and Earle 1983, Sargeant et al. 1987) or by avoiding habitats frequency by coyotes (Dekkar 1989). In east-central Illinois rural foxes selected human-associated habitats, which coyotes generally avoided (Gosselink et al. 2003). It is not uncommon for these two canids to have inverse population densities in an area (Dekkar 1989) which may explain the higher rate of fox detections on high-development lakes.

Remote cameras did not detect mink (Mustela vision) on any lakes, but was encountered on snow track surveys primarily on low-development lakes. A similar study in Ontario, Canada reported that mink occurrence and activity decreased with increase levels of residential development (Racey and Euler 1983). They revealed that mink feeding behavior and habitat use was affected by residential development. 
The higher rate of detections for white-tailed deer is probably due to supplemental feeding by humans living on the lake (pers. obs.). The presence of supplemental feeding sites can affect deer movement patterns. White-tailed deer will show a preference for feeding sites and will congregate around the area (Ozoga and Verme 1982). And natural vegetation may be affected by this increased activity around feeding sites (Doenier et al. 1997).

My snow tracking survey revealed an inverse relationship between snowshoe hare and cottontail rabbit with higher abundance of snowshoe hare observed on lowdevelopment than high-development lakes and cottontails showing the inverse. Both species live sympatrically and utilize somewhat similar habitat types (Keith and Bloomer 1993). Snowshoe hares prefer conifer forest and areas of dense brushy understory and avoid open areas (Pietz and Tester 1983, Wise 1986). Cottontails prefer a wide variety of disturbed, early successional, or shrub dominated habitats that include dense understory cover (Chapman and Litvaitis 2003). Predation is an important factor affecting abundance of cottontails in northern Wisconsin and primarily the direct cause of regulating cottontail populations (Keith and Bloomer 1993, Chapman and Litvaitis 2003). In central Wisconsin, Keith and Bloomer (1993) speculated that where snow and low temperatures are persistent throughout the winter, the cottontails' larger foot loading, brown coloration, and escape behavior make them more vulnerable to predation. They postulate that these characteristics explain cottontail absence to low abundance in northern forests of Wisconsin. Furthermore, Bueller and Keith (1982) found that 
cottontails were associated with human development and were absent in extensive forests in northern Wisconsin.

Unlike the snow tracking survey, remote cameras detected snow shoe hare and bobcats at a higher rate on high-development than low-development lakes, suggesting that like coyotes, characteristics of camera location will influence the number of photocaptures (O’Connell et al. 2006, Séquin et al. 2007). However, no cottontails were detected on low-development lakes with remote cameras, reinforcing our track survey finding that cottontails may be more abundant on high-development lakes.

Sciuridae species use a variety of habitats, adapt well to residential development (Wilson and Ruff 1999), and may benefit from supplemental feeding (i.e. bird feeders) on high-development lakes. These two survey techniques are not be the best to infer on micro-tine rodents because of there life history characteristics. For example, their smaller size may not have triggered the cameras, some species go through torpor and can be subnivean during the winter months, and are relatively cyclic in their abundance. It is unclear how residential development has affected smaller mammals in this study area.

The 2.5 times higher occurrence rate of raccoon on high-development lakes is not surprising. Several studies from throughout North America have shown that raccoon populations increase with increasing housing development and habitat fragmentation (Oehler and Litvaitis 1996, Crooks and Soulé 1999, Crooks 2002). It is well documented that raccoon densities are higher in urban and suburban areas (Hoffman and Gottschang 1977, Prange et al. 2003). Historically, raccoons were not common in northern Wisconsin (Jackson 1961) and recently have increased in abundance with wide spread 
human development. Furthermore, housing development displaces higher trophic level carnivores, such that coyotes may control raccoon populations or result in a “mesopredator release" (Soulé et al. 1988, Crooks and Soulé 1999, Schmidt 2003). A mesopredator release involves the increased density of a consumer species usually following a decline in predation by species at higher trophic levels. The increased abundance of raccoon results in higher predation rates, on lower species in the trophic level. This can cause prey populations to decline and can potentially alter community structure (Terborgh et al. 1999). Raccoons adapt well to human development (Hecht and Nickerson 1999, Prange et al. 2004) and prey heavily on bird eggs and young (Johnson et al. 1989, Sargent, et al. 1993, Schmidt 2003, McCann et al 2005). Certain avian species that nest on or near lakeshores are currently in decline, which may be due to an increase in raccoon densities and distribution (Lindsey et al 2002).

Raccoons have the most diverse diet of any carnivore in North America, which has been important in their success in human dominated landscapes (Gehrt 2004). The raccoon has probably benefited more than any other furbearer due to high human development on lakeshores. Raccoons readily exploit human garbage, pet food, and other food resources related to human activities (Gehrt 2004, Prange et al. 2004). The raccoon's climbing ability allows it to access garbage cans, dumpsters, and bird feeders which are common in residential developments. This artificial food resource has positively affected raccoon demographics throughout its range (Hoffman and Gottschang 1977, Prange et al. 2003, 2004). Raccoons often lose $50 \%$ of their body mass over winter (Mech et al. 1968), but in suburban areas, raccoons may lose only 10\% (Riley et al. 
1998). Prange et al. (2004) reported that raccoons have relatively small home ranges in urban and suburban environments in contrast to rural areas, which was due to the abundance of artificial food resources. In addition, seasonal changes in home range size were least pronounced in suburban areas (Prange et al. 2004). Furthermore, Hoffman and Gottschang (1977) documented that raccoons used linear travel routes going to and from feeding areas and home range averaged 5.5 times as long as wide. They suggested that high population densities and abundant food resources are the cause of small linear home ranges. Little is known about raccoon movement patterns in my study landscape.

The higher rate of occurrence for white-tailed deer on high-development lakes was supported by both remote camera and snow tracking surveys. Numerous studies have investigated the effect of deer over abundance and the ecological impact on landscapes. Plant communities can be devastated by deer herbivory (Beals et al. 1960, Russell et al. 2001) and wreak havoc on restoration projects (Opperman and Merenlender 2000). Opperman and Merenlender (2000) found that sapling densities were approximately ten times higher in enclosures compared to control areas and $97 \%$ of saplings in control areas displayed leaf and stem damage characteristic of deer browse. Restoration projects where there is high deer abundance should install an abatement system which can reduce herbivory and increase the success of restoration efforts (Opperman and Merenlender 2000, Sweeney et al. 2002).

Research has documented the effects on community structure when large carnivorous furbearers are removed or missing (McLaren and Peterson 1994, Berger et al. 2001, Hebblewhite et al. 2005). For example McLaren and Peterson (1994) found 
evidence supporting top-down control of a food chain by wolves on Isle Royale. Balsam fir (Abies balsamea) growth rates were regulated by moose (Alces alces) whose densities were controlled by wolf predation. When the wolf population declined moose densities expanded and suppressed fir growth (McLaren and Peterson 1994). However, presence of large carnivore (i.e. wolves and cougars) within or near residential development can be highly controversial. Unfortunately, no cougars were detected during this survey period.

Although many studies have looked at the relationships between coyotes, bobcats, and foxes in other regions of North American (Voigt and Earle 1983, Sargeant et al. 1987, Gosselink et al. 2003), there has been no research looking how these species partition their territories in this study area. In addition, it has been documented that coyotes prey on foxes (Harrison et al. 1989) supporting interspecific relationships among canid species. Few studies have investigated the relationship patterns of coyote and raccoons during major shifts in abundance (Gehrt and Clark 2003), which would support the "mesopredator release theory" caused by residential development (Soulé et al. 1988, Crooks and Soulé 1999).

\section{Conclusion}

The landscape of northern Wisconsin is unique with glacial lakes scattered in a mixed deciduous-coniferous forest. However, many lakes are ringed with residential housing developments creating a suburban setting in an undeveloped landscape. Residential development can have an effect on the spatial and movement patterns of mammal species and may differ on a larger spatiotemporal scale with specific species (Gehrt 2004). 
Though based on a relatively small sample size, the results from this project do shed some light on the mammalian diversity and species interactions on paired lakes and offer important hypotheses for future research in this area. Further monitoring and larger sample sizes may be warranted to come to more definitive conclusions.

Aldo Leopold considered maintenance of carnivores a critical test to society's commitment to conservation (Meine 1988). Though current restoration projects will restore shoreline vegetation, time will tell if this will be adequate to increase mammalian diversity and abundance on high-development lakes.

\section{Literature Cited}

Beals, E.W., G. Gottam, and R.J. Vogl. 1960. Influence of deer on vegetation of the Apostle Islands, Wisconsin. Journal of Wildlife Management. 24:68-80.

Berger, J., P.B. Stacey, L. Bellis, and M.P. Johnson. 2001. A mammalian predator-prey imbalance: grizzly bear and wolf extinction affect avian Neotropical migrants. Ecological Applications 11:947-960.

Buehler, D.A, and L.B. Keith. 1982. Snowshoe hare distribution and habitat use in Wisconsin. Canadian Field-Naturalist 96:19-29.

Buskirk, S.W., and R.A. Powell. 1994. Habitat ecology of fishers and American martens. Pages 283-296 in Buskirk, S.W., A.S Harestad, M.G. Raphael, and R.A. Powel editors, Martens, Sables, and Fishers: Biology and Conservation. Cornell University Press, Ithaca, New York. 484 pp.

Chapman, J.A., and J.A. Litvaitis. 2003. Eastern cottontail. Pages 101-125 in Feldhamer, G.A., B.C. Thompson, and J.A. Chapman editors, Wild Mammals of North America: Biology, Management, and Conservation. John Hopkins University Press, Baltimore, MY.

Crooks, K.R., and M.E. Soulé. 1999. Mesopredator release and avifaunal extinctions in a fragmented system. Nature 400:563-566.

Crooks, K.R. 2002. Relative sensitivities of mammalian carnivores to habitat fragmentation. Conservation Biology 16:488-502. 
Curtis, J.T. 1959. The vegetation of Wisconsin. University of Wisconsin Press, Madison, WI. 657 pp.

Czech, B., P.R. Krausman, and P.K. Devers. 2000. Economic associations among causes of species endangerment in the United States. BioScience 50:593-601.

Dekkar, D. 1989. Population fluctuations and spatial relationships among wolves, Canis lupus, Coyotes, Canis lantrans, and red foxes, Vulpus vulpus, in Jasper National Park, Alberta. Canadian Field Naturalist 103: 261-264.

Doenier, P.B., G.D. DelGiudice, and M.R. Riggs. 1997. Effects of winter supplemental feeding on browse consumption by white-tailed deer. The Wildlife Society Bulletin 25:235-243.

Elias, J.E., and M.W. Meyer. 2003. Comparisons of undeveloped and developed shorelands, northern Wisconsin, and recommendations for restoration. Wetlands 23:800-816.

Eisenberg, J. F. 1989. An introduction to the Carnivora. Pages 1-9 in J. L. Gittleman editor, Carnivore behavior, ecology, and revolution. Cornell University Press. Ithaca, New York, USA. 620 pp.

Fruth, K. 1986. The coyote (Canis lantrans). Wisconsin Department of Natural Resources, Bureau of Wildlife Management. PUBL-WM-148.

Gehrt, S.D., and W.R. Clark. 2003. Raccoons, coyotes, and reflections on the mesopredator release hypothesis. Wildlife Society Bulletin 31:836-842.

Gehrt, S.D. 2004. Ecology and management of striped skunks, raccoons, and coyotes in urban landscapes. Pages 81-104 in N. Fascinone, A. Delach, and M.E. Smith, editors. People and Predators: from conflict to coexistence. Island Press. Washington, D.C. 285 pp.

Gerhrt, S.D. 2007. Ecology of coyotes in urban landscapes. Wildlife Damage Management, Internet Center for Wildlife Damage Management Conferences Proceedings, University of Nebraska - Lincoln.

Gompper, M.E. 2002. Top carnivores the suburbs? Ecological and conservation issued raised by colonization of northeastern North America by coyotes. Bioscience 52:185-190.

Gonzelez-Abraham, C.E., V.C. Radeloff, R.B. Hammer, T.J Hawbaker, S.I. Stewart, and M.K. Clayton. 2007. Building patterns and landscape fragmentation in northern Wisconsin, USA. Landscape Ecology 22: 217-230. 
Gosselink T.E., T.R. Van Deelen, R.E. Warner, and M.G. Joselyn. 2003 Temporal habitat partitioning and spatial use of coyotes and red foxes in east-central Illinois. Journal of Wildlife Management 67:90-103.

Harrison, D.J., J.A. Bissonette, and J.A. Sherburne. 1989. Spatial relationships between coyotes and red foxes in eastern Maine. Journal of Wildlife Management 56:181185.

Halfpenny, J. C. 1986. A field guide to mammal tracking in North America. Johnson Printing Co. Boulder, Colorado, USA. 161 pp.

Halfpenny, J. C., R. W. Thompson, S. C. Morse, T. Holden, \& P. Rezendes. 1995. Snow-tracking. Pages 91-163 in Zeilinski, W. J., \& Kucera T. E. editors. America marten, fisher, lynx, and wolverine: survey methods for their detection. United States Forest Service General Technical Report PSW-157. 163 pp.

Hebblewhite, M., C.A. White, C.G. Nietvelt, J.A. McKenzie, T.E. Hurd, J.M. Fryxell, S.E. Bayley, adan P.C. Paquet. 2005. Human activity mediates a trophic cascade caused by wolves. Ecology 86:2135-2144.

Hecht, A., and P.R. Nickerson. 1999. The need for predator management in conservation of some vulnerable species. Endangered Species Update 16:114118.

Heinemeyer, K.S., T.J. Ulizio, and R.L. Harrison. 2008. Natural sign: tracks and scats. Pages 45-74 in Long, R.A, P. MacKay, W.J. Zielinski, and J.C. Ray editors. Noninvasive survey methods for carnivores. Island Press, Washington, D.C. 385 pp.

Hoffman, C.O., and J.L. Gottschang. 1977. Numbers, distribution, and movement of a raccoon population in a suburban residential community. Journal of Mammalogy 58:623-636.

Hoffman, R.S. 1996. Foreword. Pages xxi-xxiii in Wilson, D.E., F.R. Cole, J.D. Nichols, R. Rubran, and M.S. Foster, editors. Measuring and monitoring biological diversity: standard methods for mammals. Smithsonian Institution, Washington, D.C., USA. 409 pp.

Jackson, H.H.T. 1961. Mammals of Wisconsin. The University of Wisconsin Press. Madison, Wisconsin. 504 pp. 
Johnson, D.H., A.B. Sargeant, and R.J Greenwood. 1989. Importance of individual species of predators on nesting success of ducks in the Canadian prairie pothole region. Canadian Journal of Zoology 67:291-297.

Keith, L.B., and S.E.M. Bloomer. 1993. Differential mortality of sympatric snowshoe hares and cottontail rabbits in central Wisconsin. Canadian Journal of Zoology 71:1694-1997.

Lindsay, A.R., S.S. Gillum, and M.W. Meyer. 2002. Influence of lakeshore development on breeding bird communities in a mixed northern forest. Biological Conservation 107:1-11.

Lovallo, M.J., and E.M. Anderson. 1996. Bobcat (Lynx rufus) home range size and Habitat use in northwest Wisconsin. American Midland Naturalist 135: 241-252.

Markovchick-Nicholls, L., H.M. Regan, D.H. Deautschman, A. Widyanata, B. Martin, L. Noreke, and T.A. Hunt. 2008. Relationship between human disturbance and wildlife land use in urban habitat fragments. Conservation Biology 22: 99-109.

Magurran, A.E. 2004. Measuring Biological Diversity. Blackwell Publishing, Oxford, United Kingdom. 256 pp.

McCann, N., D.E. Haskell, and M.W. Meyer. 2005. Capturing common loon nest predators on 35mm film. Passenger Pigeon 66:351-361.

McDonald, P.T., C.K. Nielsen, T.J. Oyana, and W. Sun. 2008. Modelling habitat overlap among sympatric mesocarnivores in southern Illinois, USA. Ecological Modelling 215:276-286.

McLaren, L.D., and R.O. Peterson. 1994. Wolves, moose, and tree rings on Isle Royale. Science 266:1555-1558.

Mech, L.D., D.M. Barnes, and J.R. Tester. 1968. Seasonal weight changes, mortality, and population structure of raccoons in Minnesota. Journal of Mammalogy 49:673.

Meine, C. 1988. Aldo Leopold: his life and work. University of Wisconsin Press, Madison, Wisconsin, USA. 638 pp.

Naiman, R.J. 1996. Water, society, and landscape ecology. Landscape Ecology 11:193196.

Noss, R.F, H. B. Quigley, M. G. Hornocker, T. Merril, \& P. C. Paquet. 1996. Conservation biology and carnivore conservation in the Rocky Mountains. 
Conservation Biology. 10:949-963.

O’Connell, A.F. Jr., N.W. Talancy, L.L. Baikiley, J.R. Sauer, R. Cook, and A.T. Gilbert. 2006. Estimating site occupancy and detection probability parameters for mesoand large-mammals in a coastal ecosystem. Journal of Wildlife Management 70:1625-1633.

Oehler, J.D. and J.A. Litvaitis. 1996. The role of spatial scale in understanding responses of medium-sized carnivores to forest fragmentation. Canadian Journal of Zoology. 74:2070-2079.

Opperman, J.J, and A.M. Merenlender. 2000. Deer herbivory as an ecological constraint to restoration of degraded riparian corridors. Restoration Ecology 8:41-47.

Ozoga, J.J., and L.J. Verme. 1982. Physical and reproductive characteristics of a supplemental-fed white-tailed deer herd. Journal of Wildlife Management. 46:281-301.

Peitz, P.J., and J.R. Tester. 1983. Habitat selection by snowshoe hares in north central Minnesota. Journal of Wildlife Management. 47:686-696.

Prange, S., S. D. Gehrt, and E.P. Wiggers. 2003. Demographics factors contributing to high raccoon densities in urban landscapes. Journal of Wildlife Management 67:324-333.

Prange, S., S. D. Gehrt, and E.P. Wiggers. 2004. Influences of anthropogenic resources on raccoon (Procyon lotor) movements and spatial distribution. Journal of Mammalogy 85:483-490.

Racey, G.D., and D.L. Euler. 1982. Small mammal and habitat response to shoreline cottage development in central Ontario. Canadian Journal of Zoology 60: 865880 .

Racey, G.D., and D.L. Euler. 1983. Changes in mink habitat and food selection as influenced by cottage development in central Ontario. Journal of Applied Ecology 20:387-402.

Radeloff, V.C., R.B. Hammer, P.R. Voss, A.E. Hagen, D.R. Field, and D.J. Mladdenoff. 2001. Human demographics trends and landscape level forest management in the northwest Wisconsin Pine Barrens. Forest Science 47:229-241.

Radeloff, V.C., R.B. Hammer, and S.I. Stewart. 2005. Rural and suburban sprawl in the U.S. Midwest from 1940 to 2000 and it relation to forest fragmentation. Conservation Biology 19:793-805. 
Riera, J., P.R. Voss, S.R. Carpenter, T.K. Kratz, T.M. Lillesand, J.A. Schnaiberg, M.G. Turner, and M.W. Wegener. 2001. Nature, society and history in two contrasting landscapes in Wisconsin, USA: Interactions between lakes and humans during the twentieth century. Land Use Policy 18:41-51.

Riley, S.P.D, J. Hadidian, and D.A. Manski. 1998. Population density, survival, and rabies in raccoons in and urban national park. Canadian Journal of Zoology 76:1153-1164.

Robertson, R.J., and N.J. Flood. 1980. Effects of recreational use of shorelines on breeding bird populations. Canadian Field-Naturalist 94:131-138.

Russell, F.L., D.B. Zippin, and N.L. Fowler. 2001. Effects of white-tailed deer (Odocoileus virginianus) on plants, plant populations and communities: a review. The American Midland Naturalist. 146:1-26.

Sargeant, A.B., S.H. Allen, and J.O. Hastings. 1987. Spatial relations between sympatric coyotes and red foxes in North Dakota. Journal of Wildlife Management. $51: 283-293$

Sargent, A.B., R.J, Greenwood, M.A. Sovada, and T.L. Shaffer. 1993. Distribution and abundance of predators that effect duck production - prairie pothole region. U.S. Fish and Wildlife Service Resource Publication 194. 96 pp.

Séquin, E.S., M.M. Jaeger, P.F. Brussard, and R.H. Barrett. 2003. Wariness of coyotes to camera traps relative to social status and territory boundaries. Canadian Journal of Zoology 81:2015-2025.

Séquin, E.S., P.F. Brussard, M.M. Jaeger, and R.H. Barrett. 2007. Cameras, coyotes and the assumption of equal detectability. Journal of Wildlife Management 71:16821689 .

Schimdt, K. 2003. Nest predation and population declines in Illinois songbirds: a case for mesopredator effects. Conservation Biology 17:1141-1150.

Schmitz, O.J., P.A. Hamback, and A.P. Beckerman. 2000. Trophic cascades in terrestrial systems: A review of the effects of carnivore removal on plants. The American Naturalist. 155:141-153.

Schnaiberg, J., J. Riera, M.G. Turner, and P.R. Voss. 2002. Explaining human settlement patterns in a recreational lake district: Vilas County, Wisconsin, USA. Environmental Management 30:24-34. 
Soulé, M.E., D.T. Bolger, A.C. Alberts, J. Wright, M. Sorice, and S. Hill. 1988. Reconstructed dynamics of rapid extinctions of chaparral-requiring birds in urban habitat islands. Conservation Biology 2:75-90.

Sweeney, B.W., S.J. Czapka, and T. Yerkes. Riparian forest restoration: increasing success by reducing plant competition and herbivory. Restoration Ecology 10:392-400.

Terbourgh, J. and others. 1999. Role of top carnivores in regulating terrestrial ecosystems. In Continental Conservation: Scientific foundations of regional reserves networks, eds., Soulé, M.E., J. Terbourgh. Island Press. Washingtion, D.C.

Theobald, D.M, and J.R. Miller, N.T. Hobbs. 1997. Estimating the cumulative effects of development on wildlife habitat. Landscape and Urban Planning 39: 25-36.

Voigt, D.R., and B.D. Earle. 1983. Avoidance of coyotes by red fox families. Journal of Wildlife Management. 47:852-857.

Voigt, D.R., and E. Berg. 1987. Coyote. Pages 345-357 in Milan, N., Daker, J.A., Obbard, M.E., Malloch, editors. Wild furbearer management and conservation in North America. The Ontario Trappers Association. Ontario, Canada. 1150 pp.

WDNR. 1996. Northern Wisconsin's Lakes and Shorelands: a report examining a resource under pressure. Wisconsin Department of Natural Resources. Madison, WI 53707.

WDNR. 2005. Wisconsin Lakes. Bureau of Fisheries and Habitat Management. PUBFH-800. $180 \mathrm{pp}$.

Wilcove, D.S., D. Rothstein, J. Bubow, A. Phillips, ane E. Loso. 1998. Quantifying threats to imperiled species in the United States. Bioscience 48:607-615.

Wise, S. 1986. The snowshoe hare (Lepus americanus). Wisconsin Department of Natural Resources, Bureau of Wildlife Management. PUBL-WM-017.

Wilson, D.E., and S. Ruff. 1999. The Smithsonian book of North American Mammals. Smithsonian Institution Press, Washington, D.C. 750 pp.

Woodford, J.E., and M.W. Meyer. 2003. Impact of lakeshore development on green frog abundance. Biological Conservation 110:277-284. 
Wydeven, A.P., R.N. Schultz, and S.R. Boles. 2004. Lynx and other carnivore surveys in Wisconsin in winter 2003-2004. Section 6 Report to U.S. Fish and Wildlife Service. Wisconsin DNR, Park Falls, Wisconsin, 8 pp.

Wydeven, A.P., J.E. Wiedenhoeft, R.N. Schultz, E.A. Fromm and S.R. Boles. 2007. Lynx and other carnivore surveys in Wisconsin in winter 2006-2007. Section 6 Report to U.S. Fish and Wildlife Service. Wisconsin DNR, Park Falls, Wisconsin. 9 pp. 
Table 2.1. 2008 snow tracking survey lake characteristics in Vilas County, Wisconsin (WDNR 2005,). Low-development lakes $(<10$ houses $/ \mathrm{km}$, mean $=2.10 \pm$ 0.64) are matched with high-development lakes $(\geq 10$ houses $/ \mathbf{k m}$, mean $=23.45 \pm$ 2.69) by surface area, lake type (drainage, seepage, spring fed), and perimeter of shoreline. Paired lakes are sequenced top to bottom.

\begin{tabular}{llcccc}
\hline Development & \multicolumn{1}{c}{ Lake } & $\begin{array}{c}\text { Surface Area } \\
\text { ha }\end{array}$ & Type & $\begin{array}{c}\text { Perimeter } \\
\text { m }\end{array}$ & $\begin{array}{c}\text { House } \\
\text { Density/km }\end{array}$ \\
\hline Low & Escanaba* & 119 & DG & 8135 & 0.37 \\
& Jag* & 158 & SE & 4935 & 1.4 \\
White Sand & 220 & DG & 9881 & 5.8 \\
& Lac Du Lune & 172 & SE & 13724 & 2.0 \\
Erickson & 106 & DG & 3570 & 0.5 \\
Nebish & 40 & SE & 4295 & 0.2 \\
Palmer & 257 & DG & 10617 & 3.1 \\
Round & 47 & DG & 3586 & 0.3 \\
Little John & 67 & SP & 5369 & 2.1 \\
& Laura & 242 & SE & 8239 & 5.2 \\
& Found*† & 132 & DG & 6362 & 16.7 \\
& Moon*† & 124 & SE & 3190 & 14.7 \\
& Lost & 297 & DG & 7537 & 26.2 \\
Carpenter & 135 & SE & 5492 & 18.0 \\
& Brandy & 110 & DG & 3470 & 29.8 \\
Vandercook & 38 & SE & 3257 & 13.8 \\
Eagle & 231 & DG & 7490 & 30.2 \\
& Johnson & 32 & DG & 3546 & 26.2 \\
Towanda & 59 & SE & 6119 & 18.7 \\
Stormy & 211 & SE & 7595 & 40.2 \\
\hline
\end{tabular}

$\dagger=$ Lakes currently under shoreline restoration.

$*=$ Lakes with digital remote camera deployed

Lake type: $\mathrm{DG}=$ drainage, $\mathrm{SE}=$ seepage, $\mathrm{SP}=$ spring fed $(\mathrm{WDNR} 2005$ 
Table 2.2. Abundance index categories for non-furbearer mammals detected on snow track surveys on ten pairs of low- and high-development lakes in Vilas County, Wisconsin.

\begin{tabular}{cc}
\hline $\begin{array}{c}\text { Range of mean abundance index } \\
\text { values }\end{array}$ & $\begin{array}{c}\text { Abundance } \\
\text { Interpretation }\end{array}$ \\
\hline 0 & Absent \\
$0.1-.0 .4$ & Rare \\
$0.5-1.4$ & Uncommon \\
$1.5-2.4$ & Common \\
$>2.4$ & Abundant \\
\hline
\end{tabular}

Table 2.3. The total number of furbearer species encountered during snow track surveys on ten pairs of lakes in Vilas County, Wisconsin. Data was collected in January and February of 2008.

\begin{tabular}{cccc}
\hline \multicolumn{2}{c}{ Species } & \multicolumn{2}{c}{ Residential Development } \\
Common Name & Scientific Name & High & Low \\
\hline Coyote & Canis lantrans & 2 & 32 \\
Wolf & Canis lupus & 0 & 4 \\
Porcupine & Erethizon dorsatum & 1 & 0 \\
Otter & Lontra canadensis & 0 & 8 \\
Bobcat & Lynx rufus & 0 & 4 \\
Fisher & Martes pennanti & 0 & 8 \\
Ermine & Mustele erminea & 0 & 2 \\
Mink & Mustele vison & 1 & 5 \\
Raccoon & Procyon lotor & 2 & 0 \\
Red fox & Vulpes vulpes & 9 & 5 \\
\hline
\end{tabular}


Table 2.4. Other mammals detected during snow track surveys on ten pairs of lakes in Vilas County, Wisconsin. Species were assigned categories based on the average frequency detected on low- and high-development lakes. Categories are (0) absent, $(0.1-0.4)$ rare, $(0.5-1.4)$ uncommon, $(1.5-2.4)$ common, $(>2.4)$ abundant (see Table

2.2). Data was collected during the winter of 2008 .

\begin{tabular}{cccccc}
\hline \multicolumn{2}{c}{ Species } & \multicolumn{2}{c}{ Development } & & \\
Common Name & Scientific Name & High & Low & Test Stat & $\boldsymbol{P}$ \\
\hline Domestic Dog & Canis familiarus & 1.5 & 0.1 & $3.500^{*}$ & $<\mathbf{0 . 0 0 1}$ \\
White-tailed Deer & $\begin{array}{c}\text { Odocoileus } \\
\text { virginianus }\end{array}$ & 2.5 & 0.6 & $4.000^{*}$ & $<\mathbf{0 . 0 0 1}$ \\
$\begin{array}{c}\text { Sciuridae spp. } \\
\text { Squirrels }\end{array}$ & 2.2 & 1.4 & 1.697 & 0.107 \\
$\begin{array}{c}\text { Micro-tine } \\
\text { rodents }\end{array}$ & 0.7 & 1.1 & -1.434 & 0.169 \\
$\begin{array}{c}\text { Eastern Cottontail } \\
\text { Snowshoe Hare }\end{array}$ & $\begin{array}{c}\text { Sylvilagus floridanus } \\
\text { Lepus americanus }\end{array}$ & 1.1 & 0.1 & $14.000^{*}$ & $\mathbf{0 . 0 0 3}$ \\
\hline
\end{tabular}

*Nonparametric Mann-Whitney Rank Sum $U$-test. 

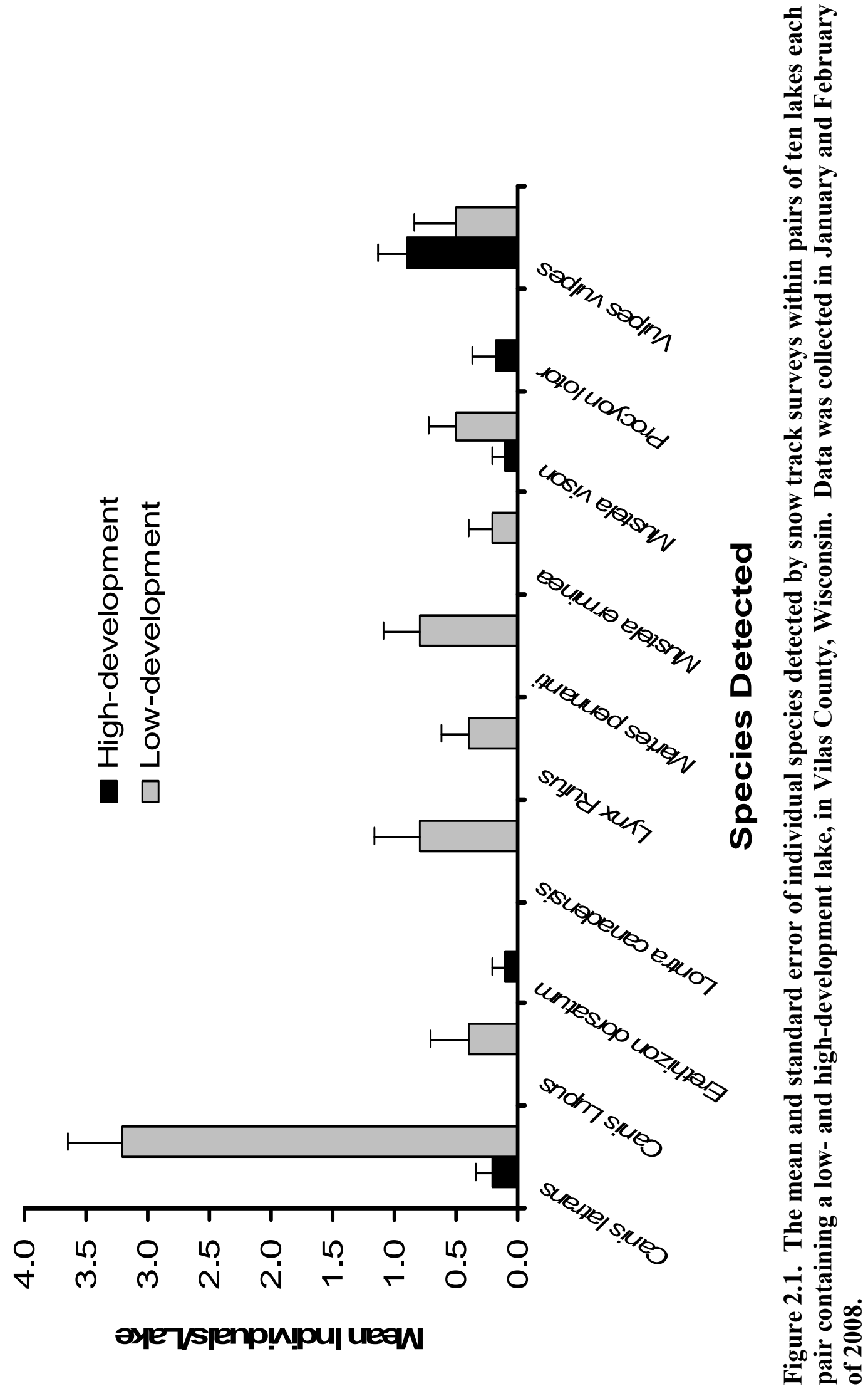


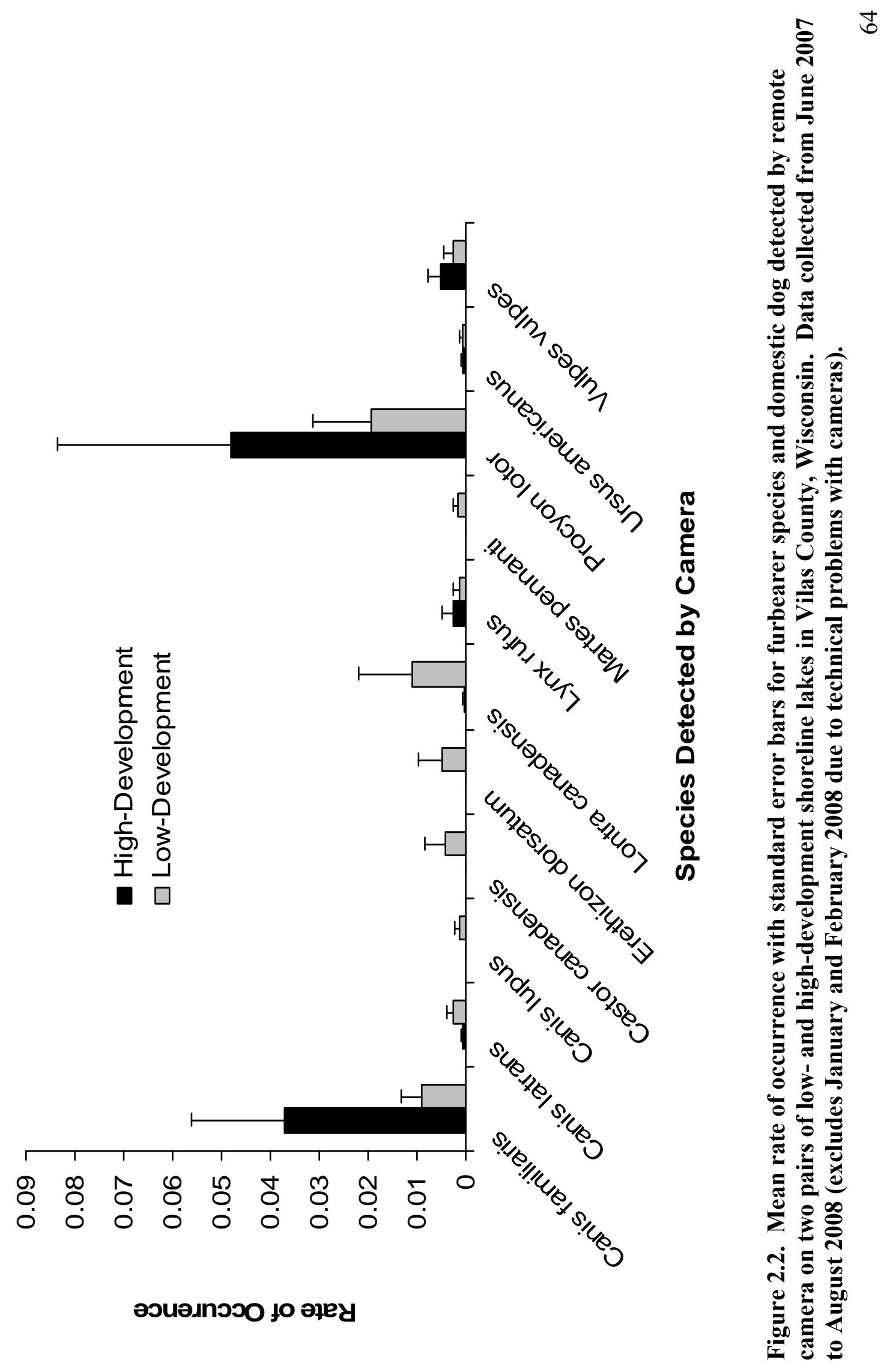




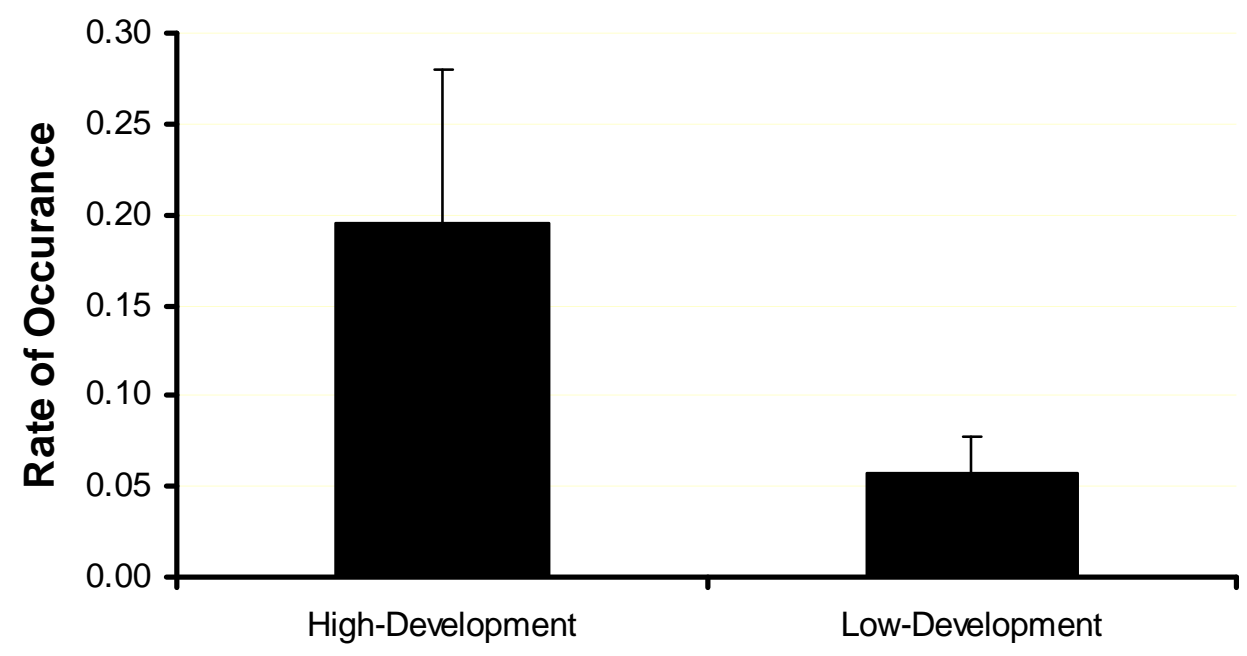

Odocoileus viginianus

Figure 2.3. Mean rate of occurrence with standard error bars for white-tailed deer (Odocoileus virginianus) detected by remote camera on two pairs of matched lowand high-development shoreline lakes in Vilas County, Wisconsin. Data collected from June 2007 to August 2008, excluding January and February 2008.

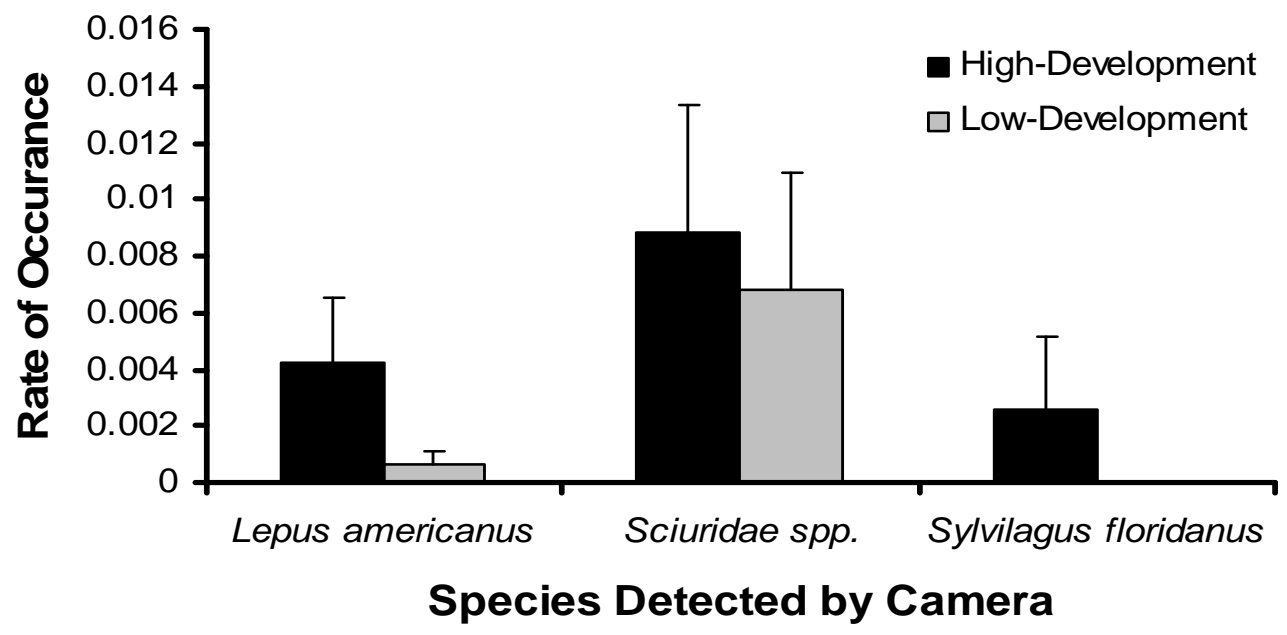

Figure 2.4. Mean rate of occurrence with standard error bars of non-furbearer mammals detected by remote camera on two pairs of matched low- and highdevelopment shoreline lakes in Vilas County, Wisconsin. Data collected from June 2007 to August 2008, excluding January and February 2008. 


\title{
CHAPTER 3
}

\section{BASELINE ASSESSMENT OF WILDLIFE HABITAT RESTORATION IN NORTHERN WISCONSIN: THE WISCONSIN LAKESHORE RESTORATION PROJECT}

\begin{abstract}
Housing development has increased dramatically in the Midwest over several decades with a high concentration around lakes. Humans remove native plants and alter vegetation structure on high-development lakes. Previous research has revealed negative effects to the local fauna and flora species on high-development lakes. Recent lakeshore restoration efforts in Vilas County, Wisconsin were implemented to curtail the negative consequences of housing development on lakeshores. However, little or nothing is known about the success of restoration in reversing the ecological effects of development. A partnership between agencies and academia has launched a long-term research project investigating the ecological benefits of lakeshore restoration. I recruited private landowners on three high-development lakes in Vilas County to participate in restoring shoreline habitat. Landowners allowed me to access their properties to gather data on wildlife species and vegetation structure characteristics in return for free lakeshore restoration services. Restoration efforts were completed on 12 properties on Found Lake from 2007-2008. Assessment of the restoration will be conducted in subsequent years by monitoring wildlife response. In addition, I tested six native shrub species for survival and canopy volume growth rates that were transplanted in the summer from bare root stock and compared them to shrubs planted from nursery containers.
\end{abstract}




\section{INTRODUCTION}

The Midwest region of the U.S. experienced a 146\% increase in housing development from 1940 to 2000 with the highest growth rate (596\%) occurring in northern Wisconsin (Radeloff et al. 2005). Northern Wisconsin contains one the highest density of freshwater glacial lakes in the world, and since 1965 the number of new houses built has increased over $200 \%$ along lakeshores (WDNR 1996, Radeloff et al. 2001). Gonzalez-

Abraham et al. (2007) suggest that lakes are the single most important factor determining both housing density and spatial pattern of housing development in this region. Their results revealed that $41 \%$ of human development occurred within $100 \mathrm{~m}$ of lakeshores in northern Wisconsin since the 1930s, and most of these buildings were within $50 \mathrm{~m}$ of each other, suggesting that even in rural areas, people will tolerate living close to one another on lakes (Gonzalez-Abraham et al. 2007). In Vilas County alone, 61\% of medium-sized (1000-3000 $\left.\mathrm{ft}^{2}\right)$ houses were within the $100 \mathrm{~m}$ of the lakeshores (Schnaiberg et al. 2002). This concentration of housing development along lakeshores can fragment wildlife habitat (Theobald et al. 1997), alter habitat use and movement patterns, and reduce local biodiversity (Wilcove et al. 1998, Czech et al. 2000).

Because of increased light and water availability, vegetation along lakeshore forest edges is often more diverse and structurally complex than in closed canopy forest (Harper and MacDonald 2001, Elias and Meyer 2003). Such riparian zones provide critical habitat for a variety of wildlife, protect water quality, and have aesthetic appeal when the shoreline is naturally vegetated (Engel and Pederson 1998). However, removal of vegetation structure along shorelines is often associated with residential development (Christensen et al. 1996, Elias and Meyer 2003, Marburg et al. 2006). 
Some lakeshore residents prefer manicured lawns and scattered trees over a natural riparian vegetation (Macbeth 1992). Such changes to vegetation can change the physical characteristics of lakes and the biological processes that occur near and within them. Several studies in the Great Lakes region have examined the influence of habitat changes associated with residential development on native plants and animals. Lindsay et al. (2002) reported foraging guilds of breeding birds differed significantly along inland lakeshore stretches with vs. without housing development; granivorous and omnivorous species were associated with high-development and insectivorous species were associated with low-development lakes. Green frog (Rana clamitans) abundance decreased with an increase in shoreline housing density (Woodford and Meyer 2003). In central Ontario, housing development on lakeshores resulted in a decline of small mammal diversity and abundance (Racey and Euler 1982) and mink (Mustela vision) behavior and diet was negatively affected (Racey and Euler 1983). In addition, certain piscivorous birds such as the Common Loon (Gavia immer), and Osprey (Pandion haliaetus) avoid lakes with a high level of human disturbance (Newbrey et al. 2005). Lakeshores with more shoreline development have less down woody material (Christensen et al. 1996) and aquatic vegetation in the littoral zone (Radomski and Goeman 2001) reducing habitat for waterfowl and fish (Moyle and Hotchkiss 1945, Jennings et al. 1999) and decreases fish growth rate and population size (Schindler et al. 2000, Sass et al. 2006).

The State of Wisconsin has attempted to protect shoreline habitat by implementing ordinances that mandate vegetation cutting standards in a buffer zone along lakeshores. The Wisconsin Shoreland Management Program (WDNR Chapter NR 115) states that vegetation within a buffer zone must be left intact for 35 feet inland from the ordinary 
high water mark and no more than 30 feet for every 100 feet of shoreline can be cleared of vegetation. The program recommends that the remaining shoreline be left in a naturally vegetated state. However, many shoreline owners routinely ignore or are unaware of these ordinances and cutting and removal of vegetation from the buffer zone is common.

Some lakeshore owners and local government agencies are interested in restoring high-development lakeshores to a more natural state. Recently, restoration efforts have been conducted on lakeshores within the $35 \mathrm{ft}$ buffer zone on high-development lakes in Vilas County, Wisconsin. However, almost nothing is known about the ecological benefits of lakeshore restoration within the $35 \mathrm{ft}$ buffer zone. Restoration efforts have been shown to improve habitat for breeding birds (Fletcher and Koford 2003) and small mammals (Patten 1997). Moreover, little is known regarding the survival and growth rates of native plant species used in such lakeshore restorations.

A collaboration of Vilas County Land and Water Conservation Department (VCLWCD), Wisconsin Department of Natural Resources (WDNR), Michigan Technological University (MTU), and Wisconsin Department of Agriculture, Trade and Consumer Protection (WDATCP) initiated a long-term $(\geq 10$ years) research project in 2007 investigating the ecological value of shoreline restoration on riparian and littoral communities in Vilas County, Wisconsin. This restoration project requires participating private property owners to plant native trees, shrubs and ground cover plants within a 35foot buffer zone along the shoreline. Three high-development lakes ( $\geq 10$ houses $/ \mathrm{km}$ ) were targeted for lakeshore restoration efforts in Vilas County. WDNR and MTU 
personnel solicited property owners to participate by offering restoration to their lakeshore free of charge.

To better understand the dynamics and benefits of lakeshore restoration, this project is an ongoing effort to compare wildlife and vegetation communities between restored and reference lakeshores, and to monitor specific bare root shrubs species for survival and growth rates in restored areas.

The objectives of this research are to: 1) gather data on vegetation structure, density and composition, breeding bird and small mammal diversity, species richness and abundance before and after restoration efforts, and monitor the response of wildlife in subsequent years ( $\geq 10$ years), 2) compare and contrast bare root plant survival and canopy volume growth rates used on restoration projects, 3 ) and provide best management restoration practices for lakeshore landowners and agencies.

This project is ongoing and the data presented in this chapter represent the results from the first year's restoration projects.

\section{METHODS}

\section{Experimental Design}

The Before-After-Control-Impact-Paired (BACIP) design was implemented to contrast $500 \mathrm{~m}$ of an impact (restoration lakeshore) with $500 \mathrm{~m}$ of a control (control lakeshore) on high-development lakes and, additionally, a paired low-development lake (reference lakeshore). The reference lakeshore are paired with restoration lakeshore with similar attributes (surface area, substrate, and lake type) as the restored shoreline and used as a reference. This design is commonly used for impact assessment with subsamples taken at 
all sites before and after treatment (Green 1979, Stewart-Oaten et al. 1992) and sites are sampled simultaneously over time (Stewart-Oaten et al. 1986).

MTU, VCLWCD, and WDNR staff developed site specific restoration plans for each participating property owner on the restoration lakeshores. Each plan was designed to provide the maximum ecological value while still integrating property owners' land-use preferences. Native plant species were used in restoration plans and soil erosion issues were addressed with various bioengineering techniques. All bioengineering techniques were approved by WDATCP engineers. Once all parties agreed on plans, property owners signed a ten-year contract with VCLWCD which states that the restoration area will not be manipulated by landowners for a ten-year period. Planting densities were based on recommendation from the Wisconsin Biology Technical Note 1: Shoreland note (NRCS 2002). A local nursery (Hanson’s Garden Village, Rhinelander, Wisconsin) supplied all plant material. A $2.4 \mathrm{~m}$ high nylon fence was erected around all restoration sites to protect plants from herbivory (Opperman and Merenlender 2000, Holmes et al. In Press).

\section{Study Area}

This project was conducted on three matched pairs of lakes (Table 3.1) in a forested landscape on deep sands with pitted glacial outwash in Vilas County, Wisconsin (Stearns and Likens 2002). Vilas County encompasses a $2636 \mathrm{~km}^{2}$ area along the state's northern border with the Upper Peninsula of Michigan. Vilas County contains 1320 pitted outwash glacial lakes ranging in size from 0.1 to $>1500$ ha and covering $16 \%$ of the county's area (WDNR 2005), and 53\% of the area is in private ownership (Schnaiberg et 
al. 2002). The land cover is a mixture of bogs, northern wet forest, boreal forest, and northern dry to northern xeric forest (Curtis 1959).

The three high-development lakes targeted for restoration are located within the Northern Highland Lake District. All three lakes were home to several fishing resorts in the past. On Found Lake (T40N, R8E, Section 14) and Lost Lake (T40N, R8E, Section 10) these resorts have been sold to developers and parceled for resale to individuals for seasonal or permanent homes. In addition, recent construction of larger dwellings has occurred with little or no regard for a vegetated buffer zone near the shoreline, though mature trees are often maintained or preserved. Found Lake's north shoreline suffered a disturbance from a wind storm in 1999 which toppled hundreds of mature trees (see Chapter One). The third lake, Moon Lake (T40N, R8E, Section 25) is currently home to Moon Beach Camp, which is affiliated with the United Church of Christ. The restoration and control sites on Found Lake are located along $1500 \mathrm{~m}$ of the north-northeast shoreline, Lost Lake $1500 \mathrm{~m}$ along the south-southwest shoreline, and Moon Lake 1200 $\mathrm{m}$ along the north and east shorelines, property of Moon Beach Camp. Reference lakes were paired with high-development lakes according to similar aspect and substrate of restoration lakeshores.

Restoration efforts were initiated on Found Lake in the summers of 2007 and 2008 with12 individual property owners. Moon Lake restoration was started in the fall of 2008 and is currently ongoing. Lost Lake restoration is pending and restoration should occur in 2009 and 2010. 


\section{Vegetation Sampling}

Each shoreline targeted for restoration, control, and reference was divided into 50 m segments using GIS (Geographic Information System) software and was labeled with numbers $(1,2,3, \ldots .$.$) . Each 50 \mathrm{~m}$ segment was divided into $10 \mathrm{~m}$ sub-segments and coded as follows 1a, 1b, 1c, 1d, 1e, 2a, 2b, 2c, 2d, 2e, etc (1a through 1e represents the first $50 \mathrm{~m}$ segment and $2 \mathrm{a}$ through $2 \mathrm{e}$ the second segment). The intention was to survey a $10 \mathrm{~m} \times 10 \mathrm{~m}\left(1\right.$ are $\left.=100 \mathrm{~m}^{2}\right)$ vegetation plot every $50 \mathrm{~m}$. An attempt was made to survey every point that fell on the letter "a" (i.e. 1a, 2a, 3a). Each survey plot always began to the right of the point (start of $10 \mathrm{~m} \times 10 \mathrm{~m}$ plot at point, end of plot to the right when facing shore from the lake). However, if a point fell on a resident's usage area or access area to the lake $\left(30^{\prime} \times 35^{\prime}\right)$ then a sub-segment was randomly picked, using a random number table, until the vegetation plot did not fall on usage or access area. For example, if plot $3 \mathrm{a}$ fell on a usage area then another point was randomly picked such as $3 \mathrm{~b}, 3 \mathrm{c}, 3 \mathrm{~d}$ or $3 \mathrm{e}$. A metal rebar $(1.25 \mathrm{~cm} \times 15 \mathrm{~cm})$ with a $1.25 \mathrm{~cm}$ flat washer welded to one end was used for a permanent survey stake and driven flush with the ground at an inland corner of the vegetation plot. The metal stakes can be relocated in subsequent years with a metal detector to resample the plots. Each plot was divided into four $5 \mathrm{~m} \times 5$ m subplots (Figure 3.1).

All living trees and woody plants in the plots that were $\geq 5 \mathrm{~cm}$ diameter breast height ( $\mathrm{dbh} ; 1.37 \mathrm{~m})$ within restored, control and reference lakeshores were identified to species and their $\mathrm{dbh}$ recorded. Trees that fell on plot lines were measured if $50 \%$ of the tree at dbh was within the plot. Two subplots were randomly chosen and all live deciduous and coniferous saplings and shrubs that were $\geq 30 \mathrm{~cm}$ in height but having $\leq 5$ 
$\mathrm{cm}$ dbh were identified to species and tallied. Tree, sapling, and shrub density were calculated for each plot and the means computed for each treatment. In order to measure canopy cover, gap fraction was calculated using a digital hemispherical photograph (Nikon Cool Pix 5000 and FC-E8 fisheye converter) at $50 \mathrm{~cm}$ above the ground and centered in each plot. Gap fraction is defined as a fraction of pixels classified as open sky in a region in the image [Gap fraction $=$ number of pixels classified as sky in a region/total number of pixels in a region (WinScanopy 2005)]. Digital hemispherical photographs were analyzed with the software WinSCANOPY (WinScanopy 2005).

I used a density board or checker board $(0.5 \mathrm{~m} \times 3 \mathrm{~m})$ with $10 \mathrm{~cm} \times 10 \mathrm{~cm}$ grid squares to measure understory foliage density and to estimate the percent cover at four different height categories $(0-0.3 \mathrm{~m}, 0.3-1 \mathrm{~m}, 1-2 \mathrm{~m}, 2-3 \mathrm{~m})$. Squares at least 50\% obstructed by green vegetation were counted and converted to a relative index of percent cover (Bibby et al. 1992). The density board was placed at $1 \mathrm{~m}, 5 \mathrm{~m}$, and $9 \mathrm{~m}$ inland from the shoreline at the edge of each plot. This gave a height and density profile within each plot at three different distances from the shoreline. Each measurement was taken 10 m away while observer and density board moved perpendicular away from the shoreline. Vegetation sampling was conducted on Found, Escanaba, Jag and Moon Lakes in 2007, while Lost and White Sand Lakes were sampled in 2008.

\section{Avian Surveys}

A dependent, double-observer $250 \mathrm{~m}$ line transect (LT) method was used to characterize breeding bird communities along targeted lakeshores. Transects were placed in three lakeshore treatments: 1) high-development lake, control, 2) high-development lake, impact (restored), and 3) low-development lake, paired (reference). Volunteers from the 
North Lakeland Discovery Center Bird Club conducted the bird surveys concurrently on each pair of lakes in two separate visits in June. Transects followed the shoreline, and all birds seen and heard on the terrestrial side of the transect were recorded and tallied. Bird surveys were conducted between 0600 and 1000 hrs. Surveys were not conducted during rain or high winds ( $>20 \mathrm{~km} / \mathrm{hr}$ ), or when wave noise influenced bird song rates and/or detectability. Bird species diversity, richness and abundance were calculated for each treatment. Bird surveys were conducted on Found, Escanaba, Jag and Moon Lakes in 2007 and 2008, while Lost and White Sand Lakes were surveyed only in 2008.

\section{Small Mammal Surveys}

Small mammal surveys were conducted in late June to late July of 2007 and 2008.

Sherman traps were placed parallel with each other and with the shoreline and within 10 $\mathrm{m}$ of the shoreline along a $250 \mathrm{~m}$ long transect. One line of traps was placed within $1 \mathrm{~m}$ of the shoreline and the second line was approximately $10 \mathrm{~m}$ from the shoreline. Traps were placed at $10 \mathrm{~m}$ intervals along both trap lines for a total of 52 traps per transect. Each trap was baited with a mixture of rolled oats and peanut butter, and a handful of polyethylene fiber was added for bedding. Traps were covered with a $1 / 2$-gallon cardboard milk container that provided captured animals with additional protection from inclement weather.

Traps were opened for 3 nights at each shoreline, checked every morning and closed, and reopened in the late evening hours. I alternated traps every other week between pairs of lakes, which resulted in two trapping sessions per treatment (lakeshore). All small mammals were identified to genus and species when possible. Data on sex, reproductive condition, overall condition, and weight were recorded for each captured 
animal; all animals were released at point of capture. Small mammal trapping was conducted on Found, Escanaba, Jag and Moon Lakes in 2007, while Lost and White Sand lakes were sampled in 2008. Each pair of lakes was trapped concurrently. If a trap door was closed and no animal captured, it was not tallied as a trap night. Small mammal diversity, richness, and abundance were calculated for each treatment.

The Deer Mouse (Peromyscus maniculatus) and the White-footed Mouse (Peromyscus leucopus) were likely to be captured on the study area; because morphological characteristics were similar, field identification was difficult and unreliable; all Peromyscus species captured in 2007 were recorded to genus only. In 2008, buccal swab samples were taken from all captured Peromyscus individuals. All buccal swap samples $(n=86)$ were genetically analyzed and identified to species at Marshfield Clinic, Marshfield, Wisconsin.

\section{Shrub survival and growth: Gravel Culture vs. Container}

I compared the survival and plant growth for several bare root native shrub species (Table 3.2) that were established in a culture of $2.5 \mathrm{~cm}$ diameter gravel at a local nursery (Hanson's Garden Village, Rhinelander, Wisconsin). This technique was relatively new and provided bare root plant stock to restoration projects throughout the planting season (Starbuck et al. 2005). Bare root shrubs, defined as gravel culture (GC), can be cost efficient, for restoration projects, costing approximately half to $3 / 4$ of the price of traditional container plants (CT) (pers. comm. Brent Hanson). A comparison of CT vs. GC for six species of shrubs planted on Found Lake in $2007(n=120)$ and was increased to 17 species in 2008 (Table 3.2). Each GC shrub was matched with a CT shrub of the same species. The pair was planted within $\leq 2 \mathrm{~m}$ of each other, and each shrub was 
identified with a unique numbered metal tag. All CT shrubs were delivered in 3-gallon nursery containers. For each shrub, one liter of organic compost was incorporated into the soil before shrubs were planted. Cedar mulch was placed around the basal area extending out $15 \mathrm{~cm}$ from base of shrubs, at approximately a depth of five $\mathrm{cm}$, and shrubs were irrigated as needed throughout the growing season. Height and canopy area of each shrub were measured at the time of planting and one year later (see Chapter One). Plant survival (alive or dead) was recorded one year after planting. A subset of matched shrubs $(n=22)$ was planted outside of the fenced restoration areas to measure the impact by local herbivores.

\section{Data analyses}

Avian and small mammal.-Shannon's Index of species diversity $\left(H^{\prime}\right)$ (Magurran 2004) was calculated for each lakeshore (restoration [Impact], control, and reference [Paired]). I used one-way ANOVA to compare the $H^{\prime}$ means between targeted lakeshores for avian, small mammal, and vegetation density data. The Kolmogorov-Smirnov test was used to test for normally distributed samples. Arcsine and natural logarithms were used to transform independent variables to meet normality assumptions. When the transformation of variables was unsuccessful in producing a normal distribution, the nonparametric Kruskall-Wallis test was substituted.

Shrubs. -A two way ANOVA test was used to compare the mean growth rates for paired shrubs in fenced and unfenced areas. The Tukey method was used for all pairwise multiple comparison tests for nonparametric data. A paired $t$-test was conducted on each species of paired shrubs within the fenced area to determine the difference in growth rate over one year. If test assumptions were not meet for shrub data, then a Wilcoxon 
Signed Rank Test was used. All analyses were conducted using SigmaStat 3.5 software (Systat Software Inc.2006) and significance levels were set at $\alpha=0.05$.

\section{RESULTS}

\section{Restoration efforts}

Restoration activities occurred on 12 private properties on Found Lake in 2007 and 2008 which approximated a $6,720 \mathrm{~m}^{2}$ restored area within the lakeshore buffer area. Approximately 12,324 ground cover plants (grasses, sedges and wildflowers) 1,941 shrubs and 220 trees were planted within this lakeshore buffer area. Approximately $1,371 \mathrm{~m}$ of $2.4 \mathrm{~m}$ high nylon fence was erected around the restoration area.

\section{Vegetation Sampling}

Though tree, sapling, and shrub densities were consistently higher on reference lakeshores relative to control and restoration lakeshores, there was no significant difference between them $(P=0.872-3.992$; Table 3.3$)$. In addition, there was no significant difference in gap fraction among shorelines $(P=0.191$; Table 3.3$)$. Understory foliage density tended to be higher on reference lakeshores at all height categories but no significant differences were found among lakeshores $(P=0.665-2.715$; Table 3.3).

\section{Avian Surveys}

In 2007, 184 individual birds were recorded representing 46 species across treatments on Found, Escanaba, Jag and Moon Lakes. Twenty-seven species along the control lakeshores accounted for $25 \%$ of all individuals recorded, 40 species along the impact lakeshores accounted for $45 \%$ of all individuals, and 37 species along the reference shorelines accounted for $35 \%$ of all individuals. In 2008,435 individuals were detected 
representing 50 species on the above lakes plus the addition of Lost and White Sand Lakes. Thirty-seven species in the control lakeshores accounted for $37 \%$ of all individuals recorded, 37 species in the restoration shorelines accounted for $31 \%$ of all individuals, and 46 species in the reference shorelines accounted for $32 \%$ of all individuals. A summary of total bird abundance, species richness, Shannon's Index of Diversity $\left(H^{\prime}\right)$, and evenness is presented by lake, treatment, and year in Table 3.4.

There was no significant difference in bird species diversity among treatments for both. Grouping birds by foraging, diet, and nesting guilds found no significant differences among treatments for both years. However, power to detect differences was low due to small sample sizes. A summary of bird guilds in presented by lake, shoreline and year in Tables 3.5-3.7.

\section{Small Mammals}

In 2007, 186 total captures of seven species were recorded from 1719 trap nights on all lakeshores transects on Found, Escanaba, Jag and Moon Lakes. Five species in the control lakeshores accounted for $17 \%$ of all individuals captured, 5 species in the restoration lakeshores accounted for $36 \%$ of all individuals captured, and 7 species in the reference lakeshores accounted for 47\% of all individuals captured. In 2008, 408 total captures of 11 species were recorded from 2832 trap nights on the above lakes plus Lost and White Sand Lakes. Ten species in the control lakeshores accounted for $30 \%$ of all individuals recorded, 8 species in the restoration lakeshores accounted for $28 \%$ of all individuals, and 9 species in the reference lakeshores accounted for $42 \%$ of all individuals. A summary of small mammal captures, species richness, $H^{\prime}$, and evenness is presented by lake, lakeshores, and year in Table 3.8. There was no significant difference 
in species diversity among lakeshores for both years for small mammal surveys (2007 P $=0.933 ; 2008 P=0.536)$. However, power to detect differences $(0.050)$ was low due to small sample sizes.

Of the 86 genetic samples collected, 66 yielded positive identification of deer mice (Peromyscus maniculatus) $(n=52)$ and white-footed mice (Peromyscus leucopus) $(n=$ 14). Eighty-three percent of deer mice were captured on reference lakeshores, $15 \%$ were captured on control lakeshores, and 2\% captured on restoration lakeshores. Twenty-eight percent of white-footed mice were captured on reference lakeshores, $36 \%$ were captured on control lakeshores, and 36\% captured on restoration lakeshores. Abundances of deer $(P=0.062)$ and white-footed mice $(P=0.967)$ were not significantly different between lakeshores. The power of the performed test $(0.437-0.050)$ is below the desired power of 0.800 . However, there is evidence suggesting that deer mice may be associated with reference lakeshores (Figure 3.2). In addition, evidence suggests that eastern chipmunks (Tamias striatus) are more abundant control and restoration lakeshores (Figure 3.3) however there were no significant differences among lakeshores for both years (2007 $P=$ 0.533; $2008 P=0.113$ ). The Least Chipmunk (Tamias minimus) was captured 27 times in 2007, all on restoration lakeshores which occurred only on Found Lake. In 2008, the Least Chipmunk was captured $82 \%$ of 38 captures on the restoration lakeshores and $8 \%$ captures occurred on control lakeshores of Found Lake. A summary of small mammal captures for both years is presented in Table 3.9.

\section{Shrub survival and growth}

There was no significant difference in the change of percent canopy volume between GC and $\mathrm{CT}$ shrubs $(P=0.682)$ however, there was a significant difference in percent canopy 
volume $\left(F_{3,236}=11.867, \mathrm{P}=<0.001\right)$ between fenced $($ mean $=0.729 \pm 0.104)$ and unfenced shrubs which experienced a negative growth rate (mean $-0.111 \pm 0.220)$. A paired $t$ - test between GC and CT revealed a significant difference for two shrub species, common ninebark (Physocarpus opulifolius) $(n=16, W=78.000, P=0.044)$ and snowberry (Symphoricarpos Albus) $(n=40, W=-308.000, P=0.039)$ in mean growth over one year. Common ninebark CT had a four times higher percent change in canopy volume $($ Mean $=2.457 \pm 0.678)$ compared to GC shrubs $($ mean $=0.604 \pm 0.345)$, suggesting that the CT out performed the GC. On the other hand, snowberry GC grew three times more $($ mean $=0.278 \pm 0.0953)$ more than the CT shrubs $($ mean $=0.097 \pm$ $0.084)$.

\section{DISCUSSION}

When large scale systems are studied, it can be impractical and sometimes impossible (i.e. cost) to include the ideal number of replicates (Green 1979, Hulbert 1984). Most restoration projects are conducted on a site-specific basis with no replication; the effect of the restoration is indicated by the difference on site before and after treatment (Green 1979, Underwood 1994). However, the problem that arises from this design is that observed changes may be the result of natural variation over time and not from the restoration efforts (Hulbert 1984). One of the common shortcomings of the BACIP design is the lack of replications which limits the inference drawn from the results (Hulbert 1984). To counter this problem, Underwood (1991) suggested taking measurements at multiple times before and after the restoration. With this in mind, the results of the vegetation sampling, avian and small mammal surveys from this project 
should be interpreted as before-restoration data because restoration on Found Lake was initiated in 2007 and continued in 2008, providing two years of data prior to restoration.

Recent investigations of residential shoreline development on terrestrial and aquatic communities (e.g., Elias and Meyer 2003, Lindsey et al. 2002, Woodford and Meyer 2003) found that substantial physical and biological differences between developed and undeveloped shorelines. For example, Elias and Meyer (2003) reported a reduction of sub-canopy and shrub layer coverage on high-development lakes compared to lowdevelopment lakes. They found a two-fold increase in shrub coverage and half as much tree coverage on low-development lakes compared to high-development lakes (Elias and Meyer 2003). Here, we found approximately three times the density on undeveloped reference lakeshores compared to control and restoration lakeshores. Tree and sapling densities were also higher on reference lakeshores. Undeveloped referenced lakeshores also had higher foliage density at all height categories, a result similar to that found by Robertson and Flood (1980). Robertson and Flood (1980) found lower vertical structural diversity of foliage on high-development lakes in southern Ontario, Canada. However, it is important to note that in our study, Found Lake experienced a natural wind disturbance event in 1999 (see Chapter 1). It is well known that understory vegetation densities and structure increases after canopy disturbance (Oliver and Larson 1996). Thus, Found Lake may be going through an early successional period relative to the high-development along the lakeshores. Furthermore, several property owners on Found Lake own over $100 \mathrm{ft}$ of shoreline (the minimum length stated in WDNR Chapter NR 115). Such properties have less human disturbance compared to properties with the minimum 
requirement of $100 \mathrm{ft}$ (pers. obs.). Further investigation at the micro-site level may reveal more robust results.

It is well known that riparian areas offer diverse habitat features and niches for many bird species (Naiman et al. 1993), and development along riparian areas can have a detrimental effect to bird communities. Lindsey et al. (2002) paired high-development lakes with low-development lakes of similar physical characteristics and performed point-counts around the perimeter of each lake to assess bird community structure. Their results revealed that several species and certain resource-selection guilds responded either negatively or positively to lake development. Ground nesting and insectivorous birds were more common on low-development lakes. Granivorous birds had approximately twice the abundance on control and restoration lakeshores as they did on reference lakeshores. As with the Lindsey et al. (2002) study, we found no significant difference in species diversity between lakeshores. However, unlike Lindsey et al. (2002), we found no differences in nesting, foraging and diet guilds among lakeshores. There is evidence suggesting that certain ground nesting birds are more abundant on reference lakes. For example, Black-and-White Warbler (Mniotilta varia) and Ovenbirds (Seiurus aurocapillus) occurred twice as often on reference lakes as on control and impact shorelines. Lindsey et al. (2002) reports the Black-and-White Warbler was associated with low-development lakes. The presence of species diversity around development raises some important questions about habitat-specific reproductive success and productivity along developed vs. undeveloped shoreline. Little is known about the correlation of nest predation rates with low-and high-development lakes. Previous 
studies suggest that an increase of raccoon (Procyon lotor) and feral cats (Felis catus) predation rates are associated with human development (Schmidt and Whelan 1998).

Regarding small mammals, our findings are similar to those of Racey and Euler (1982) in central Ontario. In their study, eastern chipmunks were associated with higher residential density along inland lakeshores. In our study, the high numbers of eastern chipmunks on control and restoration lakeshores compared to the reference lakeshores suggest eastern chipmunks are also associated with high-development lakeshores. Secondary products of residential development such as bird feeders and human garbage may be important to eastern chipmunks as a source for supplemental food. The deer mouse was the most frequently captured species on reference lakeshores. Racey and Euler (1982) reported that deer mice abundance was negatively correlated with human development in central Ontario, Canada. The inverse relationship between deer mouse abundance and lake development suggests the same maybe true in northern Wisconsin. The presence of white-footed mice also raises additional questions. Historically, whitefooted mice were found in the southern three quarters of the state with a preference for deciduous forests (Jackson 1961). Currently, it may be moving slowly northward with the habitat alterations, climate change, and/or forest management practices.

Using bare root shrubs is not a new practice in restoration projects. Traditionally, bare root shrubs were used during the period from frost-free soil to bud break in the spring and defoliation to frozen soil in the fall (Starbuck et al. 2005). Bare root nursery stock can be cost efficient and provide handling ease and soil conservation as compared to container nursery stock (Starbuck et al. 2005). However, it has a restrictive time frame for use, a slower establishment time (Johnson et al. 1984), and greater susceptibilty to 
desiccation during transporting and planting (Starbuck et al. 2005). Starbuck et al. (2005) looked at using gravel as a medium to extend the use of bare roots throughout the summer months. They investigated this technique for red oak (Quercus rubra) and green ash (Fraxinus pennsylanica) and reported no mortality. Our study investigated this technique on six native shrubs at a local nursery (Hanson's Garden Village, Rhinelander, Wisconsin) and integrated them into restoration projects as gravel culture nursery stock. The results overall revealed no significant difference in GC and CT across species. Ninebark was the only shrub that did not fair as well as other species used for GC. Ninebark can grow on sandy, gravelly, rocky soils, can be found along banks and lakeshores (Soper and Heimburger 1994), and is highly recommended by county conservationist and local nursery personnel. Additional investigation of this shrub is warranted. The shrubs in the unfenced area suffered from white-tailed deer (Odocoileus virginianus) herbivory, and shrub growth was drastically reduced. Similar findings were reported by Opperman and Merenlender (2000) where restoration of saplings in riparian zone had a higher rate of survival in enclosures compared to control areas, and $97 \%$ of saplings in control areas displayed leaf and stem damage characteristics of deer browse. Furthermore, Holmes et al. (In Press) investigated the survival of Canada yew (Taxus canadensis) for four growing seasons and reported that deer exclusion had the most influence on survival. Restoration projects where there is high deer abundance should install an abatement system to reduce herbivory and increase growth and survival of plantings (Opperman and Merenlender 2000, Holmes et al. In Press). Recent research in the area revealed high abundance of white-tailed deer on high-development lakes (see Chapter Two). 
A human affinity for settlement near water appears widespread and in northern Wisconsin, this pattern of residential development has a long tradition. By 1931, summer homes were already present on most of the accessible lakes in the region (Murphy 1931). Humans like to live in open and natural-looking areas (Gobster and Rickenbach 2004) and open water acts as a center of organization within the landscape (Naiman 1996). However, this clustering of development causes habitat fragmentation and displaces wildlife. In many ecosystems, riparian areas play a disproportionate role in maintaining biodiversity and ecosystem functions (Naiman et al. 1993).

With the current interest in lakeshore restoration this study provides valuable ecological information to agency personnel and practical restoration techniques to landowners and restoration practitioners, and should enlighten policy makers. This study is one of the first of its kind in the area. Future research should be designed to provide insight into how specific land use patterns associated with lakeshore development and specific human activities influence ecological communities.

The challenges of conserving and restoring the intricate web of life was the subject of a quote from Dobson et al (1997, p 521): "There is a direct analogy with engineering: It is a relatively straightforward exercise to take apart an ecosystem or an automobile engine, yet quantifying the relative number of parts in an automobile engine (or an ecosystem) tells us little about how it functions. In contrast, reassembling the engine (or the ecosystem) will reveal a deeper level of understanding of how each of its components functions." 


\section{LITERATURE CITED}

Christensen, D.L., B.R. Herwig, D.E Schindler, and S.R. Carpenter. 1996. Impacts of lakeshore residential development on coarse woody debris in north temperate lakes. Ecological Applications 6:1143-1149.

Clark, K.L., D.L. Euler, and E. Armstrong. 1984. Predicting avian community response to lakeshore cottage development. Journal of Wildlife Management 48:12391247.

Curtis, J.T. 1959. The vegetation of Wisconsin. University of Wisconsin Press, Madison, WI. 657 pp.

Czech, B., P.R. Krausman, and P.K. Devers. 2000. Economic associations among causes of species endangerment in the United States. BioScience 50:593-601.

Dobson, A.P., A.D. Bradshaw, and A.J.M. Baker. 1997. Hopes for the future: restoration ecology and conservation biology. Science 277:515-521.

Elias, J.E., and M.W. Meyer. 2003. Comparisons of undeveloped and developed shorelands, northern Wisconsin, and recommendations for restoration. Wetlands 23:800-816.

Engle, S. and J.L. Pederson, Jr. 1998. The construction, aesthetics, and effects of lakeshore development: a literature review. Wisconsin Department of Natural Resources PUBL-SS-577-99.

Fletcher, R.J. Jr., and R.R. Kofored. 2003. Changes in breeding bird populations with habitat restoration in northern Iowa. American Midland Naturalist 150: 83-94.

Gobster, P.H., and M.G. Rickenbach. 2004. Private forestland parcelization and development in Wisconsin's Northwoods: perceptions of resource-oriented stakeholders. Landscape and Urban Planning. 69:165-182.

Gonzelez-Abraham, C.E., V.C. Radeloff, R.B. Hammer, T.J Hawbaker, S.I. Stewart, and M.K. Clayton. 2006. Building patterns and landscape fragmentation in northern Wisconsin, USA. Landscape Ecology.

Green, R.H. 1979. Sampling design and statistical methods for environmental biologist. John Wiley and Sons, New York. 257 pp.

Harper, K.A., and S.E. MacDonald. 2001. Structure and composition of riparian boreal forest: new methods for analyzing edge influence. Ecology 82: 649-659. 
Hulbert, S.A. 1984. Pseudoreplication and the design of ecological field experiments. Ecological Monographs 54:187-211.

Jackson, H.H.T. 1961. Mammals of Wisconsin. The University of Wisconsin Press. Madison, Wisconsin. $504 \mathrm{pp}$

Jennings, M.J., M.A. Bozek, G.R. Hatzenbeler, E.E. Emmons, and M.D. Staggs. 1999. Cumulative effects of incremental shoreline habitat modification on fish assemblages in north temperate lakes. North American Journal of Fisheries Management 19:18-27.

Johnson, P.S., S.L. Novinger, and W.G. Mares. 1984. Root, shoot, and leaf area growth potentials of northern red oak planting stock. Forest Science 30:1017-1026.

Lindsay, A.R., S.S. Gillum, and M.W. Meyer. 2002. Influence of lakeshore development on breeding bird communities in a mixed northern forest. Biological Conservation 107:1-11.

Macbeth, E.J. 1992. Protecting aesthetics and the visual resource of lakes. In Enhancing the states' lake management programs. North American Lake Management Society, Washington, D.C. 112 pp.

Magurran, A.E. 2004. Measuring Biological Diversity. Blackwell Publishing, Oxford, United Kingdom. 256 pp.

Marburg, A.E, M.G. Turner, and T.K Kratz. 2006. Natural and anthropogenic variation in coarse wood among and within lakes. Journal of Ecology 94:558-568.

Moyle, J.B. and N. Hotchkiss. 1945. The aquatic and marsh vegetation of Minnesota and its value to waterfowl. Minnesota Department of Conservation. Technical Bulletin 3. 122pp.

Murphy, R.E. 1931. The geography of the northwestern pine barrens of Wisconsin. Transaction of Wisconsin Academic Science, Arts, and Letters. 26:96-120.

Naiman, R.J., H. Décamps, and M. Pollock. 1993. The role of riparian corridors in maintaining regional biodiversity. Ecological Applications 3:209-212.

Naiman, R.J. 1996. Water, Society, and landscape ecology. Landscape Ecology. 11:193-196.

Newbrey. J.L., M.A Bozek, and N.D. Niemuth. 2005. Effects of lake characteristics and human disturbance on the presence and of piscivorous birds in northern Wisconsin, USA. Waterbirds 28:478-486. 
NRCS (Natural Resource Conservation Service). 2002. Wisconsin Biology Technical Note 1: Shoreland Habitat. NRCS. ftp://ftpfc.sc.egov.usda.gov/WI/technotes/biology-tn1.pdf

Oliver, C.D., and B.C. Larson. 1996. Forest Stand dynamics. John Wiley and Sons, Inc. $520 \mathrm{pp}$.

Opperman, J.J, and A.M. Merenlender. 2000. Deer herbivory as an ecological constraint to restoration of degraded riparian corridors. Restoration Ecology 8:41-47.

Patten, M.A. 1997. Reestablishment of a rodent community in restored desert scrub. Restoration Ecology 5:156-161.

Racey, G.D., and D.L. Euler. 1982. Small mammal and habitat response to shoreline cottage development in central Ontario. Canadian Journal of Zoology 60: 865880 .

Racey, G.D., and D.L. Euler. 1983. Changes in mink habitat and food selection as influenced by cottage development in central Ontario. Journal of Applied Ecology 20:387-402.

Radeloff, V.C., R.B. Hammer, P.R. Voss, A.E. Hagen, D.R. Field, and D.J. Mladdenoff. 2001. Human demographics trends and landscape level forest management in the northwest Wisconsin Pine Barrens. Forest Science 47:229-241.

Radeloff, V.C., R.B. Hammer, and S.I. Stewart. 2005. Rural and suburban sprawl in the U.S. Midwest from 1940 to 2000 and it relation to forest fragmentation. Conservation Biology 19:793-805.

Radomski, P., and T.J. Goeman. 2001. Consequences of human lakeshore development on emergent and floating-leaf vegetation abundance. North American Journal of Fishery Management 21:46-61.

Robertson, R.J., and N.J. Flood. 1980. Effects of recreational use of shorelines on breeding bird populations. Canadian Field Naturalist 94:131-138.

Sass, G.G., J.F. Kitchell, S.R. Carpenter, T.R. Hrabik, A.E. Marburg, M.G. Turner. 2006. Fish community and food web responses to a whole-lake removal of coarse woody habitat. Fisheries 31:321-330..

Schindler, D.E., S.I. Geib, and M.R. Williams. 2000. Patterns of Fish Growth along a residential development gradient in north temperate lakes. Ecosystems 3:229237. 
Schnaiberg, J., J. Riera, M.G. Turner, and P.R. Voss. 2002. Explaining human settlement patterns in a recreational lake district: Vilas County, Wisconsin, USA. Environmental Management 30:24-34.

Schmidt, K.A. and C.J. Whelan. 1998. Predator-mediated interactions between and with guilds of nesting songbirds: experimental and observational evidence. The American Naturalist. 152:393-402.

Soper, J.H., and M.L. Heimburger. 1994. Shrubs of Ontario. Royal Ontario Museum. Toronto, Canada. 495 pp.

Stearns, F., and G.E. Likens. 2002. One hundred years of recovery of a pine forest in Northern Wisconsin. American Midland Naturalist. 148:2-19.

Starbuck, C., D.K. Struve, and H. Mathers. 2005. Bare root and balled-and burlapped red oak and green ash can be summer transplanted using the Missouri gravel bed system. HortTechnology 15: 122-127.

Stewart-Oaten, A., W.W. Murdoch, and K.R. Parker. 1986. Environmental impact assessment: "pseudoreplication" in time? Ecology 67: 929-940.

Stewart-Oaten, A., J.R. Bence, and G.W. Osenberg. 1992. Assessing effects of unreplicated perturbations: no simple solutions. Ecology 73:1396-1404.

Theobald, D.M, and J.R. Miller, N.T. Hobbs. 1997. Estimating the cumulative effects of development on wildlife habitat. Landscape and Urban Planning 39: 25-36.

Underwood, A.J. 1991. Beyond BACI: experimental designs for detecting environmental impacts on temporal variations in natural populations. Australian Journal of Marine and Freshwater Research. 52: 569-587.

Underwood, A.J. 1994. On beyond BACI: sampling designs that might reliably detect environmental disturbances. Ecological Applications. 4: 3-15.

WDNR. 1996. Northern Wisconsin's Lakes and Shorelands: a report examining a resource under pressure. Wisconsin Department of Natural Resources. Madison, WI 53707.

WDNR. 2005. Wisconsin Lakes. Bureau of Fisheries and Habitat Management. PUBFH-800. $180 \mathrm{pp}$.

Wilcove, D.S., D. Rothstein, J. Bubow, A. Phillips, ane E. Loso. 1998. Quantifying threats to imperiled species in the United States. Bioscience 48:607-615. 
WinScanopy. 2005. WinSCANOPY 2005a for hemispherical image analysis. Regent Instruments Inc, Canada.

Woodford, J.E., and M.W. Meyer. 2003. Impact of lakeshore development on green frog abundance. Biological Conservation 110:277-284. 
Table 3.1. Characteristics of restoration and reference lakes in Vilas County, Wisconsin (WDNR 2005,). Low-development lakes ( $<10$ houses $/ \mathbf{k m})$ are paired with high-development lakes $(\geq 10$ houses $/ \mathbf{k m}$ ) by surface area, lake type (drainage, seepage, spring fed), and perimeter of shoreline. Paired lakes are in order as seen below.

\begin{tabular}{|c|c|c|c|c|c|}
\hline Development & Lake & $\begin{array}{c}\text { Surface Area } \\
\text { ha }\end{array}$ & Type $^{a}$ & $\begin{array}{c}\text { Perimeter } \\
\text { m }\end{array}$ & $\begin{array}{c}\text { House } \\
\text { Density/km }\end{array}$ \\
\hline \multirow[t]{3}{*}{ Low } & Escanaba & 119 & $\mathrm{DG}$ & 8135 & 0.37 \\
\hline & Jag & 64 & $\mathrm{SE}$ & 4935 & 1.4 \\
\hline & White Sand & 220 & DG & 9881 & 5.8 \\
\hline \multirow[t]{3}{*}{ High } & Found & 132 & DG & 6362 & 16.7 \\
\hline & Moon & 50 & $\mathrm{SE}$ & 3190 & 14.7 \\
\hline & Lost & 297 & DG & 7537 & 26.2 \\
\hline
\end{tabular}

${ }^{a}$ Lake type: $\mathrm{DG}=$ drainage, $\mathrm{SE}=$ seepage, $\mathrm{SP}=$ spring fed (WDNR 2005)

Table 3.2. Shrubs species used to compare difference of survival and plant growth between gravel culture and container nursery stock. Shrubs were planted on restoration projects in Vilas County, Wisconsin.

Shrubs

Year and Total Planted

\begin{tabular}{cccc} 
Common Name & Scientific name & $\mathbf{2 0 0 7}$ & $\mathbf{2 0 0 8}$ \\
\hline American Elder & Sambucus Canadensis & 12 & 14 \\
American Hazelnut & Corylus Americana & 0 & 2 \\
Beaked Hazelnut & Corylus cornuta & 0 & 26 \\
Black Chokeberry & Aronia melanocarpa & 52 & 46 \\
Bush Honeysuckle & Diervilla lonicera & 0 & 30 \\
Canada Serviceberry & Amelanchier Canadensis & 0 & 24 \\
Choke Cherry & Prunus virginana & 0 & 5 \\
Grey Dogwood & Cornus racmosa & 30 & 6 \\
High Bush Cranberry & Viburnum opulus & 0 & 4 \\
Ninebark & Physocarpus opulifolius & 42 & 2 \\
Pin Cherry & Prunus pensylvanica & 0 & 2 \\
Red-osier Dogwood & Cornus Stonelifera & 14 & 24 \\
Nannyberry & Viburnum lentago & 0 & 8 \\
Snow berry & Symphoricarpos Albus & 90 & 38 \\
Staghorn Sumac & Rhus typhina & 0 & 30 \\
Winterberry & Ilex verticillata & 0 & 8 \\
\hline
\end{tabular}


Table 3.3. Vegetation data collected on riparian lakeshore of three paired lakes in Vilas County, Wisconsin. Density was calculated for $\mathrm{m}^{2}$ for each shoreline. Gap fraction was determined by digital hemispherical photograph.

\begin{tabular}{|c|c|c|c|c|c|c|}
\hline Variable & $\begin{array}{c}\text { Shoreline } \\
\text { (Treatment) }\end{array}$ & $N$ & Mean & $\begin{array}{c}\text { Std. } \\
\text { Error }\end{array}$ & $\overline{F_{1,2}}$ & $\bar{P}$ \\
\hline \multirow[t]{4}{*}{ Tree Density } & & & & & 3.992 & 0.111 \\
\hline & Reference & 3 & 0.151 & 0.029 & & \\
\hline & Control & 3 & 0.098 & 0.005 & & \\
\hline & Restoration & 3 & 0.081 & 0.005 & & \\
\hline \multirow[t]{4}{*}{ Sapling Density } & & & & & 0.872 & 0.485 \\
\hline & Reference & 3 & 0.040 & 0.006 & & \\
\hline & Control & 3 & 0.030 & 0.007 & & \\
\hline & Restoration & 3 & 0.032 & 0.002 & & \\
\hline \multirow[t]{4}{*}{ Shrub Density } & & & & & 0.928 & 0.485 \\
\hline & Reference & 3 & 0.074 & 0.050 & & \\
\hline & Control & 3 & 0.026 & 0.009 & & \\
\hline & Restoration & 3 & 0.027 & 0.011 & & \\
\hline \multirow[t]{4}{*}{ Gap Fraction } & & & & & 0.191 & 0.831 \\
\hline & Reference & 3 & 19.227 & 4.881 & & \\
\hline & Control & 3 & 21.598 & 0.530 & & \\
\hline & Restoration & 3 & 18.838 & 3.315 & & \\
\hline \multicolumn{7}{|l|}{$\begin{array}{l}\text { Understory Foliage } \\
\text { Density }(\%)\end{array}$} \\
\hline \multirow[t]{4}{*}{$0-0.3 \mathrm{~m}$} & & & & & 2.672 & 0.148 \\
\hline & Reference & 3 & 66.4 & 10.2 & & \\
\hline & Control & 3 & 36.9 & 07.8 & & \\
\hline & Restoration & 3 & 44.1 & 10.1 & & \\
\hline \multirow[t]{4}{*}{$0.3-1 \mathrm{~m}$} & & & & & 2.715 & 0.145 \\
\hline & Reference & 3 & 49.7 & 13.7 & & \\
\hline & Control & 3 & 23.8 & 01.4 & & \\
\hline & Restoration & 3 & 30.4 & 03.1 & & \\
\hline \multirow[t]{4}{*}{$1-2 \mathrm{~m}$} & & & & & 0.714 & 0.527 \\
\hline & Reference & 3 & 43.0 & 17.0 & & \\
\hline & Control & 3 & 25.3 & 06.1 & & \\
\hline & Restoration & 3 & 30.6 & 04.5 & & \\
\hline \multirow[t]{4}{*}{$2-3 \mathrm{~m}$} & & & & & 0.665 & 0.548 \\
\hline & Reference & 3 & 46.2 & 16.2 & & \\
\hline & Control & 3 & 29.1 & 08.1 & & \\
\hline & Restoration & 3 & 33.8 & 05.0 & & \\
\hline
\end{tabular}


Table 3.4. Summary of bird species richness (S), total bird abundance (N), Shannon's index of diversity ( $\left.H^{\prime}\right)$, and evenness (E) separated by lake, treatment and year for three paired lakes in Vilas County, Wisconsin. Lost and White Sand Lakes were not surveyed in 2007.

\begin{tabular}{cccccccccc}
\hline Lake & Treatment & \multicolumn{4}{c}{2007} & \multicolumn{5}{c}{2008} \\
& & $\mathrm{~S}$ & $\mathrm{~N}$ & $H^{\prime}$ & $\mathrm{E}$ & $\mathrm{S}$ & $\mathrm{N}$ & $H^{\prime}$ & $\mathrm{E}$ \\
\hline Found $^{\mathrm{a}}$ & Control & 21 & 36 & 2.88 & 0.94 & 27 & 53 & 3.16 & 0.96 \\
& Restoration & 18 & 31 & 2.70 & 0.93 & 32 & 55 & 3.30 & 0.95 \\
Escanaba $^{\mathrm{b}}$ & Reference & 27 & 34 & 3.24 & 0.98 & 28 & 55 & 3.18 & 0.96 \\
Moon $^{\mathrm{a}}$ & Control & 14 & 20 & 2.56 & 0.97 & 18 & 36 & 2.71 & 0.94 \\
& Restoration & 18 & 34 & 2.79 & 0.96 & 15 & 23 & 2.61 & 0.96 \\
Jag $^{\mathrm{b}}$ & Reference & 17 & 28 & 2.68 & 0.95 & 16 & 35 & 2.64 & 0.95 \\
Lost $^{\mathrm{a}}$ & Control & NA & NA & NA & NA & 22 & 74 & 2.80 & 0.91 \\
& Restoration & NA & NA & NA & NA & 22 & 43 & 2.97 & 0.96 \\
White Sand $^{\mathrm{b}}$ & Reference & NA & NA & NA & NA & 27 & 51 & 3.11 & 0.94 \\
\hline $\begin{array}{l}\text { a }=\text { High development lake } \\
\text { b= Low development lake }\end{array}$ & & & & & & & & \\
\hline
\end{tabular}

Table 3.5. Summary of bird foraging guild richness (G), total bird abundance within guides $(\mathrm{N})$, Shannon's index of diversity $\left(H^{\prime}\right)$, and evenness $(E)$ separated by lake, treatment and year for three paired lakes in Vilas County, Wisconsin.

Calculations based on Magurran (2004).

\begin{tabular}{|c|c|c|c|c|c|c|c|c|c|}
\hline \multirow[t]{2}{*}{ Lake } & \multirow[t]{2}{*}{ Treatment } & \multicolumn{4}{|c|}{2007} & \multicolumn{4}{|c|}{2008} \\
\hline & & $\mathrm{G}$ & $\mathrm{N}$ & $H^{\prime}$ & $\mathrm{E}$ & $\mathrm{G}$ & $\mathrm{N}$ & $H^{\prime}$ & $\mathrm{E}$ \\
\hline \multirow[t]{2}{*}{ Found $^{\mathrm{a}}$} & Control & 7 & 25 & 1.67 & 0.86 & 7 & 36 & 1.67 & 0.83 \\
\hline & Restoration & 6 & 20 & 1.52 & 0.91 & 9 & 49 & 1.49 & 0.68 \\
\hline Escanaba $^{\mathrm{b}}$ & Reference & 7 & 32 & 1.68 & 0.86 & 7 & 43 & 1.59 & 0.89 \\
\hline \multirow[t]{2}{*}{ Moon $^{\mathrm{a}}$} & Control & 6 & 19 & 1.24 & 0.69 & 6 & 26 & 1.80 & 1.00 \\
\hline & Restoration & 8 & 25 & 1.75 & 0.84 & 6 & 31 & 1.36 & 0.76 \\
\hline $\mathrm{Jag}^{\mathrm{b}}$ & Reference & 7 & 23 & 1.68 & 0.86 & 7 & 20 & 1.33 & 0.68 \\
\hline \multirow[t]{2}{*}{$\operatorname{Lost}^{\mathrm{a}}$} & Control & NA & NA & NA & NA & 8 & 66 & 1.53 & 0.74 \\
\hline & Restoration & NA & NA & NA & NA & 9 & 47 & 1.71 & 0.78 \\
\hline White Sand ${ }^{b}$ & Reference & NA & NA & NA & NA & 4 & 34 & 1.48 & 1.07 \\
\hline
\end{tabular}


Table 3.6. Summary of bird diet guild richness (G), total bird abundance within guild $(N)$, Shannon's index of diversity $\left(H^{\prime}\right)$, and evenness $(E)$ separated by lake, treatment and year for three paired lakes in Vilas County, Wisconsin. Calculations based on Magurran (2004).

\begin{tabular}{cccccccccc}
\hline Lake & Treatment & \multicolumn{4}{c}{2007} & \multicolumn{5}{c}{2008} \\
& & $\mathrm{G}$ & $\mathrm{N}$ & $H^{\prime}$ & $\mathrm{E}$ & $\mathrm{G}$ & $\mathrm{N}$ & $H^{\prime}$ & $\mathrm{E}$ \\
\hline Found $^{\mathrm{a}}$ & Control & 5 & 30 & 1.23 & 0.77 & 5 & 41 & 1.21 & 0.75 \\
& Restoration & 4 & 24 & 0.94 & 0.68 & 6 & 55 & 0.95 & 0.53 \\
Escanaba $^{\mathrm{b}}$ & Reference & 4 & 32 & 0.58 & 0.42 & 4 & 41 & 0.81 & 0.58 \\
Moon $^{\mathrm{a}}$ & Control & 4 & 19 & 1.12 & 0.81 & 4 & 30 & 0.25 & 0.18 \\
& Restoration & 4 & 23 & 1.01 & 0.73 & 4 & 22 & 0.23 & 0.17 \\
Jag $^{\mathrm{b}}$ & Reference & 4 & 20 & 0.59 & 0.73 & 4 & 29 & 0.26 & 0.19 \\
Lost $^{\mathrm{a}}$ & Control & $\mathrm{NA}$ & $\mathrm{NA}$ & $\mathrm{NA}$ & $\mathrm{NA}$ & 4 & 64 & 1.11 & 0.80 \\
& Restoration & NA & NA & NA & NA & 3 & 30 & 0.47 & 0.47 \\
White Sand $^{\mathrm{b}}$ & Reference & NA & NA & NA & NA & 4 & 47 & 0.93 & 0.67 \\
\hline
\end{tabular}

${ }^{\mathrm{a}}=$ High development lake

$\mathrm{b}=$ Low development lake 
Table 3.7. Summary of bird nesting guild richness (G), total bird abundance within guild (N), Shannon's index of diversity $\left(H^{\prime}\right)$, and evenness (E) separated by lake, treatment and year for three paired lakes in Vilas County, Wisconsin. Calculations based on Magurran (2004).

\begin{tabular}{cccccccccc}
\hline Lake & Treatment & \multicolumn{4}{c}{2007} & \multicolumn{4}{c}{2008} \\
& & $\mathrm{G}$ & $\mathrm{N}$ & $H^{\prime}$ & $\mathrm{E}$ & $\mathrm{G}$ & $\mathrm{N}$ & $H^{\prime}$ & $\mathrm{E}$ \\
\hline Found $^{\mathrm{a}}$ & Control & 6 & 25 & 1.51 & 0.84 & 5 & 38 & 1.50 & 0.93 \\
& Restoration & 5 & 23 & 1.58 & 0.98 & 6 & 55 & 1.43 & 0.80 \\
Escanaba $^{\mathrm{b}}$ & Reference & 5 & 32 & 1.46 & 0.90 & 5 & 40 & 1.50 & 0.92 \\
Moon $^{\mathrm{a}}$ & Control & 6 & 17 & 1.53 & 0.86 & 5 & 27 & 1.28 & 0.80 \\
& Restoration & 6 & 24 & 1.62 & 0.90 & 7 & 21 & 1.73 & 0.89 \\
Jag $^{\mathrm{b}}$ & Reference & 6 & 22 & 1.65 & 0.92 & 6 & 28 & 1.65 & 0.92 \\
Lost $^{\mathrm{a}}$ & Control & $\mathrm{NA}$ & $\mathrm{NA}$ & $\mathrm{NA}$ & $\mathrm{NA}$ & 5 & 61 & 1.36 & 0.85 \\
& Restoration & $\mathrm{NA}$ & $\mathrm{NA}$ & $\mathrm{NA}$ & $\mathrm{NA}$ & 5 & 33 & 1.50 & 0.92 \\
White Sand $^{\mathrm{b}}$ & Reference & $\mathrm{NA}$ & $\mathrm{NA}$ & $\mathrm{NA}$ & $\mathrm{NA}$ & 6 & 47 & 1.62 & 0.90 \\
\hline
\end{tabular}

${ }^{\mathrm{a}}=$ High development lake

$\mathrm{b}=$ Low development lake 
Table 3.8. Summary of small mammal species richness (S), total small mammal abundance $(N)$, Shannon's index of diversity $\left(H^{\prime}\right)$, and evenness $(E)$ separated by lake, treatment and year for three paired lakes in Vilas County, Wisconsin. Lost and White Sand Lakes were not surveyed in 2007. Calculations based on Magurran (2006).

\begin{tabular}{|c|c|c|c|c|c|c|c|c|c|}
\hline \multirow[t]{2}{*}{ Lake } & \multirow[t]{2}{*}{ Treatment } & \multicolumn{4}{|c|}{2007} & \multicolumn{4}{|c|}{2008} \\
\hline & & $\mathrm{S}$ & $\mathrm{N}$ & $H^{\prime}$ & $\mathrm{E}$ & $\mathrm{S}$ & $\mathrm{N}$ & $H^{\prime}$ & $\mathrm{E}$ \\
\hline \multirow[t]{2}{*}{ Found $^{\mathrm{a}}$} & Control & 5 & 27 & 1.17 & 0.72 & 5 & 32 & 1.42 & 0.88 \\
\hline & Restoration & 7 & 56 & 1.22 & 0.63 & 6 & 79 & 1.41 & 0.79 \\
\hline Escanaba $^{\mathrm{b}}$ & Reference & 2 & 39 & 0.38 & 0.55 & 4 & 37 & 0.91 & 0.79 \\
\hline \multirow[t]{2}{*}{ Moon $^{\mathrm{a}}$} & Control & 3 & 5 & 0.34 & 0.53 & 5 & 48 & 0.89 & 0.55 \\
\hline & Restoration & 3 & 31 & 0.34 & 0.31 & 4 & 40 & 0.73 & 0.53 \\
\hline $\mathrm{Jag}^{\mathrm{b}}$ & Reference & 5 & 28 & 1.28 & 0.79 & 5 & 27 & 0.83 & 0.60 \\
\hline \multirow[t]{2}{*}{$\operatorname{Lost}^{\mathrm{a}}$} & Control & NA & NA & NA & NA & 5 & 41 & 1.05 & 0.65 \\
\hline & Restoration & NA & NA & NA & NA & 5 & 50 & 0.42 & 0.48 \\
\hline White Sand ${ }^{b}$ & Reference & NA & NA & NA & NA & 4 & 51 & 0.75 & 0.55 \\
\hline
\end{tabular}




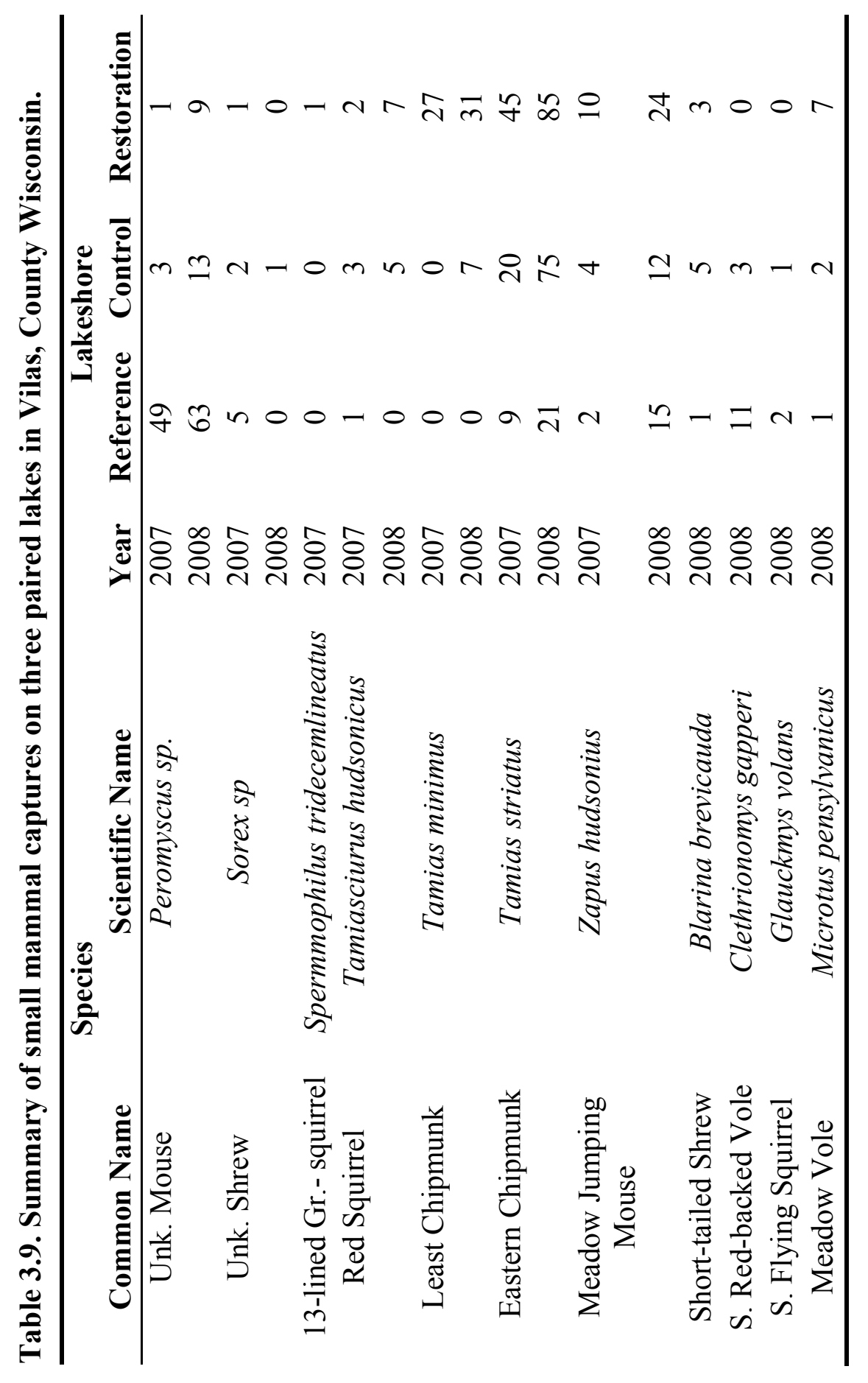




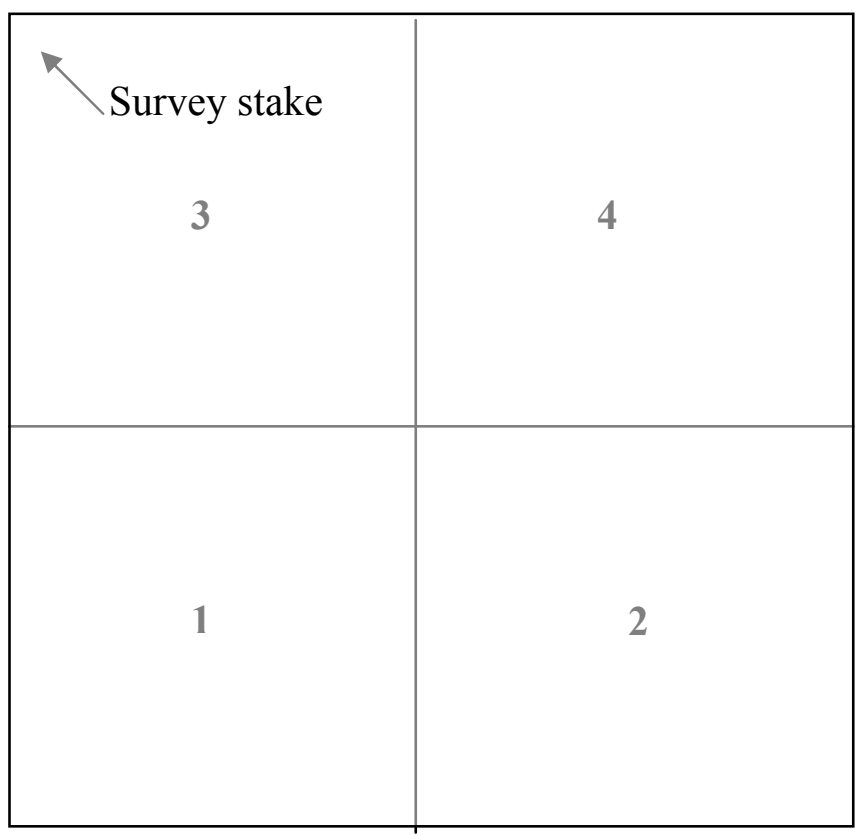

$\longleftarrow$ Lake Shoreline

Figure 3.1. Example of $10 \mathrm{~m} \times \mathbf{1 0} \mathrm{m}$ vegetation sampling plot with four $5 \mathrm{~m} \times \mathbf{5} \mathrm{m}$ subplots on research shorelines in northern Wisconsin. All live trees $\geq 5 \mathrm{~cm}$ DBH were recorded in plot and live saplings and shrubs were recorded in two subplots. Figure 3.1 shows location of survey stake. 


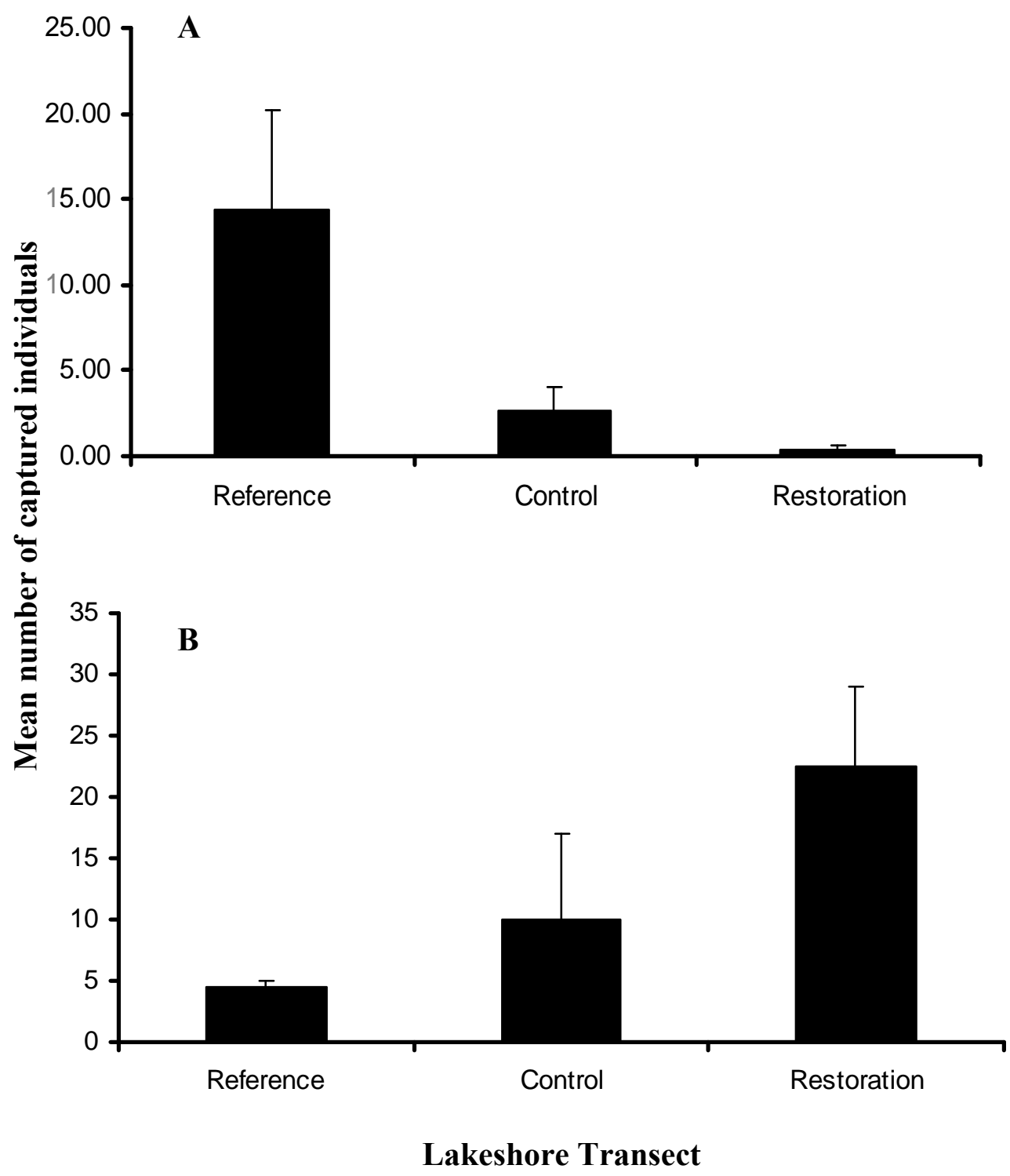

Figure 3.2. Means and standard errors of Deer Mouse (Peromyscus maniculatus) (A) and White-footed Mouse (Peromyscus leucopus) (B) captured on three paired lakes in Vilas County, Wisconsin in 2008. 


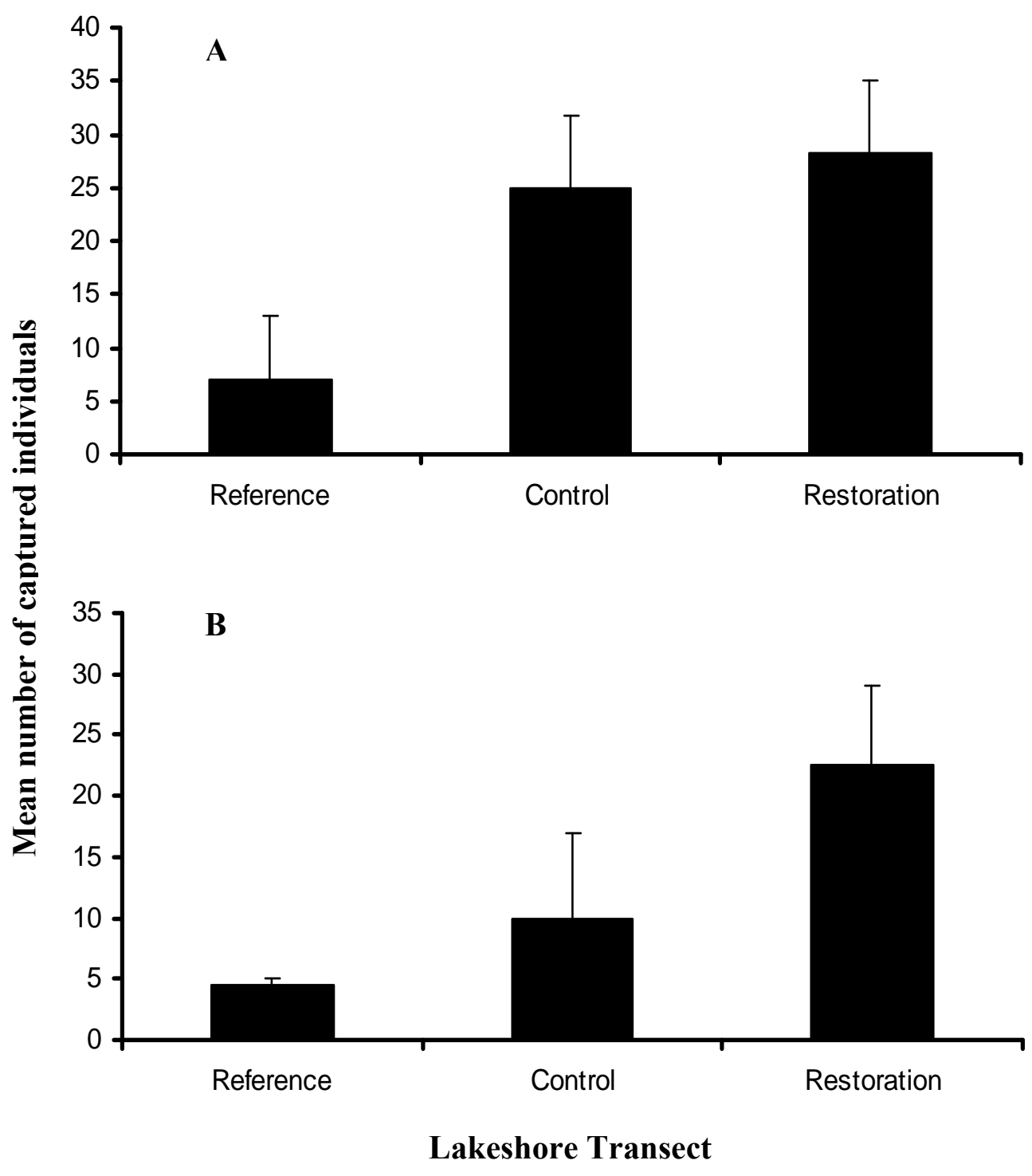

Figure 3.3. Means and standard errors of Eastern Chipmunk (Tamias striatus) in 2008 (A) and 2007 (B) captured on three paired lakes in Vilas County, Wisconsin. 